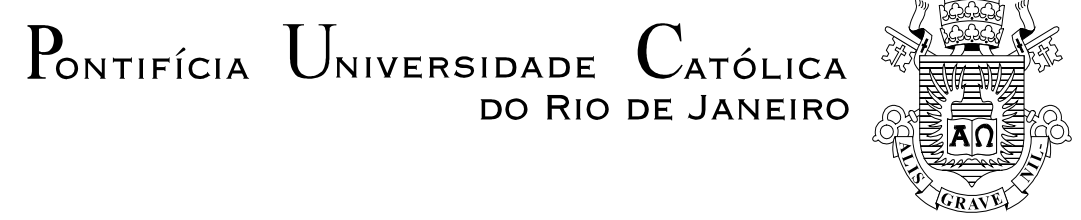

Taciana Mareth

\title{
Technical efficiency in dairy farms: research synthesis and an application in the South of Brazil
}

\author{
TESE DE DOUTORADO
}

Thesis presented to the Programa de Pós-Graduação em Engenharia de Produção of the Departamento de Engenharia Industrial, PUC-Rio as partial fulfillment of the requirements for the degree of Doutor em Engenharia de Produção.

Advisor: Prof. Luiz Felipe Roris Rodriguez Scavarda do Carmo Co-Advisor: Prof. Antônio Márcio Tavares Thomé

Rio de Janeiro

September 2015 


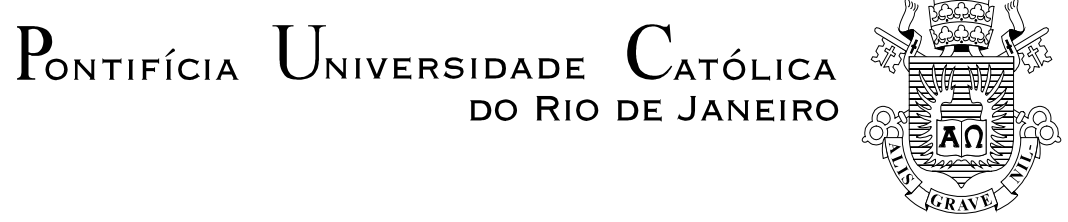

Taciana Mareth

Technical efficiency in dairy farms: research synthesis and an application in the South of Brazil

Thesis presented to the Programa de Pós-Graduação em Engenharia de Produção of the Departamento de Engenharia Industrial do Centro Técnico Científico da PUC-Rio, as partial fulfillment of the requirements for the degree of Doutor.

Prof. Luiz Felipe R. R. Scavarda do Carmo

Advisor

Departamento de Engenharia Industrial - PUC-Rio

Prof. Antônio Márcio Tavares Thomé

Co-Advisor

Departamento de Engenharia Industrial - PUC-Rio

Prof. Tiago Wickstrom Alves

Universidade do Vale do Rio dos Sinos - UNISINOS

Prof. Guilherme Luís Roehe Vaccaro

Universidade do Vale do Rio dos Sinos - UNISINOS

Prof. Nélio Domingues Pizzolato

Departamento de Engenharia Industrial - PUC-Rio

Prof. Fernando Luiz Cyrino Oliveira

Departamento de Engenharia Industrial - PUC-Rio

Prof. José Eugenio Leal

Coordinator of the Centro Técnico Científico da PUC-Rio

Rio de Janeiro, September 16th, 2015 
All rights reserved

\section{Taciana Mareth}

Taciana Mareth is Accounting Specialist from the University of Cruz Alta and have a Master of Sciences in Accounting (Concentration Area: Accounting and Control) from the University of Vale dos Sinos (UNISINOS). She was a professor of Business Administration, Accounting and Management of Rural Enterprises at the University of Cruz Alta. She participated as a coordinator and as team member in research projects funded by the University of Cruz Alta and the Foundation for the Support of Research in the Rio Grande do Sul, Brazil (FAPERGS).

Bibliographic data

Mareth, Taciana

Technical efficiency in dairy farms: research synthesis and an application in the South of Brazil / Taciana Mareth; advisor: Luiz Felipe Roris Rodriguez Scavarda do Carmo; co-advisor: Antônio Márcio Tavares Thomé. - 2015.

125 f.; $30 \mathrm{~cm}$

Tese (doutorado) - Pontifícia Universidade Católica do Rio de Janeiro, Departamento de Engenharia Industrial, 2015.

Inclui bibliografia

1. Engenharia Industrial - Teses. 2. Meta-regressão. 3. Modelos de fronteira. 4. Eficiência técnica. 5. Propriedades produtores de leite. 6. Determinantes da eficiência técnica. I. Carmo, Luiz Felipe Roris Rodriguez Scavarda do. II. Thomé, Antônio Márcio Tavares. III. Pontifícia Universidade Católica do Rio de Janeiro. Departamento de Engenharia Industrial. IV. Título. 


\section{Acknowledgements}

I thank God for supporting me, for giving me a life full of opportunities and strengths to achieve the stated objectives.

I thank the four most important people in my life Abílio, Anadir, Jonas and Valéria for the love, support and encouragement to never giving up my dreams. To family and friends for caring, supporting and understanding the absence throughout the journey.

For my teachers Evandro Rottini Fistarol and Leonardo Díaz Morales for their support, friendship and the transmitted knowledge.

To the professors from Universidade de Cruz Alta and Universidade do Vale do Rio dos Sinos, for the friendship and support throughout my walk.

To my professors of the Graduate Program - $\mathrm{PhD}$ in Accounting Production Engineering, the knowledge imparted throughout the course, especially to Angela da Rocha, José Eugênio Leal, Luiz Felipe Roris Scavarda do Carmo, Nélio Domingues Pizzolato, Paulo Roberto Tavares Dalcol and Renato de Viveiros Lima.

To the first advisor Professor Nélio Domingues Pizzolato for his guidance, support, and academic directions. To the professors and advisors, Luiz Felipe Roris Rodriguez Scavarda do Carmo and Antônio Márcio Tavares Thomé, for having accepted the guidance during the doctoral process. They gave me the opportunity to receive their valuable lessons which enabled the development of this research. To the professors Fernando Luiz Cyrino Oliveira and Tiago Wickstron Alves for the important contributions to the development of the thesis. To the doctorate colleagues, for the peaceful coexistence and the exchange of experiences. Especially to colleagues and friends for the persistence and companionship: Aldo Perez, Alessandra Pasqualina Viola, Augusto Reis, Cristina Lubrano, Dey Rodrigues, Felipe Jardim, Gilberto Figueira da Silva, Henrique 
Helfer Hoeltgebaum, Katharine de Angeli, Marcelo Pereira da Costa, Martine Gude Aamodt, Milena Cabral Aguiar, Norma Carvalho, Paula Ceryno, Pedro Lobato, Rafael Lema and Ramon Diego.

To the Postgraduate Program Secretariat staff because they contributed in one way or another to the accomplishment of my goal: Fernanda Lopes, Gilvan Nascimento and Isabel Finoti. In special Claudia Teti, by support throughout the course.

CNPQ, CAPES and the PUC-Rio, the aid given and by great study environment.

In general, to everybody who directly or indirectly contributed, supported and were willing to help throughout the course of this study, prompting me to believe in my capability which would accomplish this stage. 


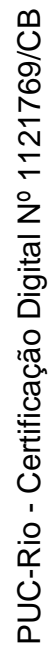

The river reaches their goals because they learned to work around obstacles

(Lao-tsé) 


\section{Abstract}

Mareth, Taciana; Carmo, Luiz Felipe Roris Rodriguez Scavarda do (Advisor); Thomé, Antônio Márcio Tavares (Co-Advisor). Technical efficiency in dairy farms: research synthesis and an application in the South of Brazil. Rio de Janeiro, 2015, 125p. D.Sc. Thesis - Departamento de Engenharia Industrial, Pontifícia Universidade Católica do Rio de Janeiro.

There is a growing number of publications on Technical Efficiency (TE) of dairy farms, due to the political, economic and social relevance of the theme as well as to its academic appeal. The goal of this thesis is two-fold: first, it presents a research synthesis on TE in dairy farms conducting both a meta-synthesis and a meta-regression analysis and, second, an empirical study aiming at measuring and understanding the factors affecting the TE in dairy farms of selected municipalities in the South of Brazil. The research synthesis embraces 103 papers published between 1987 and 2014 in 54 sources using a rigorous and reproducible approach to select studies. This synthesis complements and extends previous literature reviews on TE in dairy farms, offering a synthesis framework (i.e., context and determinants, inputs, outputs and measurement techniques of $\mathrm{TE}$ ) and analysing the effects of different methodologies and study-specific characteristics on Mean TE (MTE) through meta-regression. Findings point to no agreement among authors on context and determinants of TE. The analysis of determinants led to verifiable research propositions: the main determinants of TE are geographical location (altitude, quality of the soil, climate), farm size, investments in veterinary care, feeding and milking practice, TE model estimation techniques, public policy, and management-related variables. Results from the meta-regression analysis of the gathered papers totalling $531 \mathrm{TE}$ observations in dairy farms worldwide are discussed and makes two important contributions: (i) it updates and compares previous works on frontier estimation of TE in dairy farms and (ii) it adds two dimensions of dairy farms, size (herd and land area) and economic development, to the known differentials of TE measurement. The variation in the MTE indexes reported in the literature can be explained by the methodology of estimations (method of estimation, functional form of frontier models, model dimensionality), farms geographical location and farm size. Additionally, the results suggest that, given the state of technology prevailing in each region at the time that the studies on TE were conducted, dairy farmers in the sample could increase milk output by $20.1 \%$ (level of inefficiency), on average, if they produce on their frontiers. Implications for dairy farmers and for future research close the research synthesis. The propositions and hypotheses emerged from the research synthesis and were tested using data obtained in a survey conducted in selected municipalities in the South of Brazil. The mensuration of level TE combined with benchmark analysis helps the producers improve the degree of efficiency. This empirical study measured and helped in the understanding of the main factors affecting the TE in dairy farms from these municipalities, shedding new empirical lights in the academic literature.

\section{Keywords}

Meta-regression; frontier models; technical efficiency; dairy farms; systematic literature review; milk production; determinants of technical efficiency. 


\section{Resumo}

Mareth, Taciana; Carmo, Luiz Felipe Roris Rodriguez Scavarda do (Orientador); Thomé, Antônio Márcio Tavares (Co-orientador). Eficiência técnica em explorações leiteiras: síntese de pesquisa e uma aplicação no sul do Brasil. Rio de Janeiro, 2015, 125p. Tese de Doutorado - Departamento de Engenharia Industrial, Pontifícia Universidade Católica do Rio de Janeiro.

O número de publicações sobre Eficiência Técnica (TE) de explorações leiteiras vem crescendo nos últimos tempos devido à relevância política, econômica e social do tema, bem como ao seu apelo acadêmico. O objetivo desta tese é duplo: apresentar uma síntese de pesquisa sobre a TE em explorações leiteiras, desenvolvendo tanto uma análise de meta-síntese quanto uma análise de meta-regressão; apresentar um estudo empírico com o objetivo de mensurar e compreender os fatores que afetam a TE em propriedades leiteiras nos municípios selecionados no Sul do Brasil. A síntese de pesquisa (análise de meta-síntese e análise de meta-regressão) abrange 103 artigos publicados entre 1987 e 2014 em 54 fontes diferentes usando uma abordagem rigorosa e reprodutível para selecionar estudos. Esta síntese complementa e amplia as revisões de literatura anteriores apresentando um quadro de síntese (contexto e determinantes, entradas, saídas e técnicas de mensuração da TE) por meio da análise de conteúdo. Em seguida, a meta-regressão foi aplicada para analisar os efeitos que as diferentes metodologias e que as características específicas de cada estudo têm sobre a média da TE (modelos I ao IV - subseção 3.1.3). Os resultados da análise de meta-síntese indicam que não há um acordo entre os autores sobre o contexto e os determinantes da TE. A análise dos determinantes levou a proposições de pesquisa verificáveis. Os principais determinantes da TE são: a localização geográfica (altitude, qualidade do solo, clima), o tamanho da propriedade, os investimentos em cuidados veterinários, alimentação e práticas de ordenha, modelo de estimativa da TE, políticas públicas, e gestão relacionada com as variáveis. Os resultados da análise de meta-regressão (total de 531 distribuições do índice de TE em explorações leiteiras baseado nos 103 artigos da amostra) são discutidos e têm-se duas contribuições importantes: (i) o estudo atualiza e compara trabalhos anteriores sobre a TE em fazendas leiteiras e (ii) acrescenta duas dimensões das explorações leiteiras: tamanho (número de vacas e hectares de terra) e o desenvolvimento econômico. A variação nos índices de TE relatados na literatura pode ser explicada pela metodologia das estimativas (método de estimação, forma funcional, dimensionalidade do modelo), pela localização geográfica das fazendas e pelo tamanho da propriedade. Além disso, os resultados sugerem que, dado o estado da tecnologia predominante em cada região no momento em que os estudos sobre TE foram realizados, os produtores de leite na amostra poderiam aumentar a sua produção de leite em 20,1\% (nível de ineficiência), em média, se eles produzirem em suas fronteiras de eficiência. Implicações para os produtores de leite e para pesquisas futuras é validar essa síntese de pesquisa. A partir dessa síntese de pesquisa, algumas proposições e hipóteses que emergiram foram testadas usando os dados obtidos em uma pesquisa realizada em municípios selecionados no Sul do Brasil. Este estudo empírico mensurou a TE para cada propriedade de leite e identificou aquelas que apresentam as melhores práticas (benchmarks). A mensuração do nível de TE combinada com a análise das melhores práticas auxilia os produtores a melhorar seu grau de eficiência. Em seguida, utilizando outros dois modelos de meta-regressão (V e VI - subseção 3.2.3), o estudo empírico auxiliou no entendimento dos principais fatores que afetam essa TE, derramando novas luzes empíricas na literatura acadêmica.

\section{Palavras-chave}

Meta-regressão; modelos de fronteira; eficiência técnica; propriedades produtores de leite; revisão sistemática da literatura; produção de leite; determinantes da eficiência técnica. 


\section{Summary}

Technical efficiency: definitions and measurement techniques

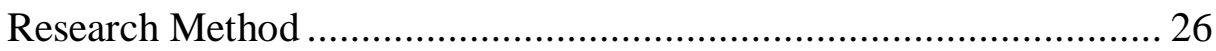

3.1

Research synthesis

26

3.1.1

Sample selection...

26

3.1.2

Content analysis

Meta-regression analysis.

3.2

Empirical study....

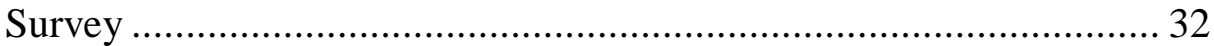

3.2 .2

DEA model.

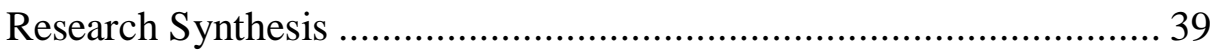

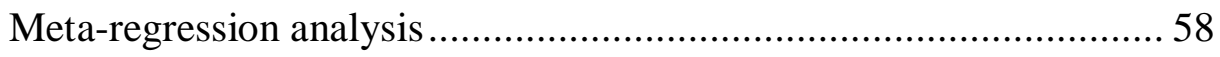

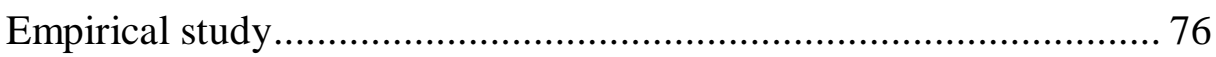

\section{2}

Estimated TE

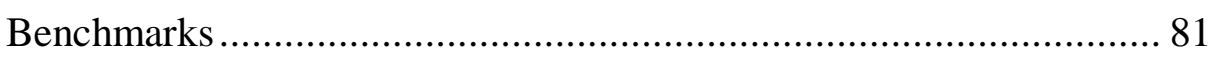

5.3 


\section{List of Tables}

Table 1: Overview of inputs, outputs used, and farmer characteristics ( $n=253) \ldots \ldots . . .33$

Table 2: Studies identification of TE in dairy farms............................................ 40

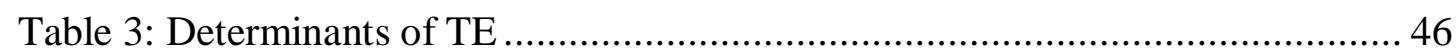

Table 4: Classification of inputs, outputs and metrics........................................ 51

Table 5: Overview of empirical studies of TE in dairy farms ................................ 58

Table 6: Average mean TE (AMTE) by methodological characteristics.................. 62

Table 7: Average Mean TE (AMTE) by geographical region and country’s income

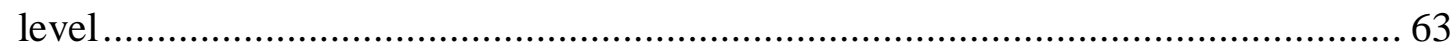

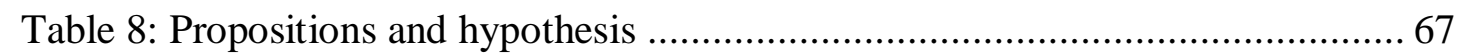

Table 9: Tobit meta-regressions of MTE in dairy farms...................................... 69

잉

Table 11: Sample distribution of the estimated TE ............................................. 77

Table 12: Comparison of technically efficient and less technical efficient farmers... 78

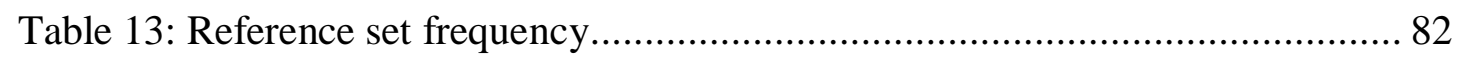

Table 14: Potential improvement (\%) for inefficient DMUs ................................. 83

Table 15: DEA results for Farm T3 under CRS model......................................... 83

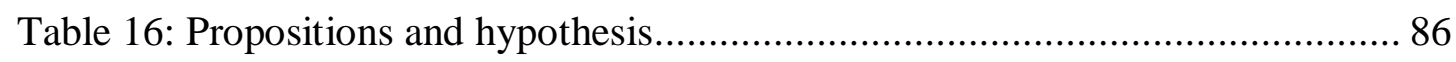

Table 17: OLS and Tobit regression of TE in dairy farms.................................... 88

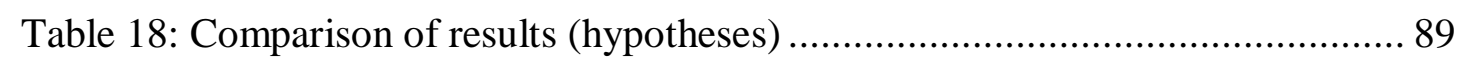




\section{List of Figures}

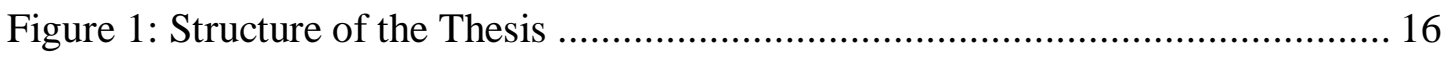

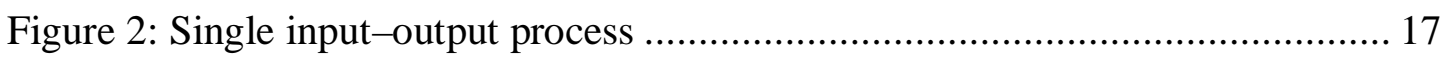

Figure 3: A summary view of frontier models ..................................................... 19

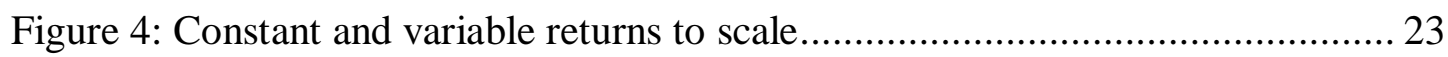

Figure 5: Results of the literature review by selection steps and database ................ 28

Figure 6: Synthesis of the Thesis organization and methods ................................. 37

Figure 7: Number of publications on TE in dairy farms in five-year groups

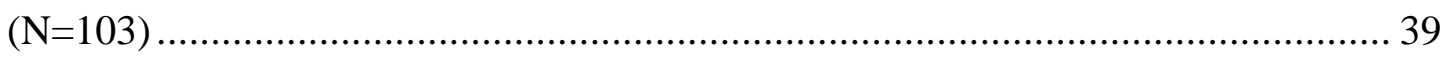

Figure 8: Research synthesis framework …......................................................... 43

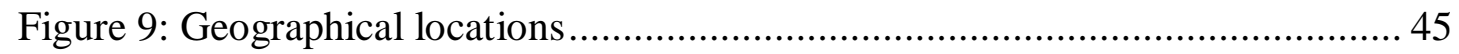

Figure 10: Sample distribution of the TE of the CRS and VRS model (input-

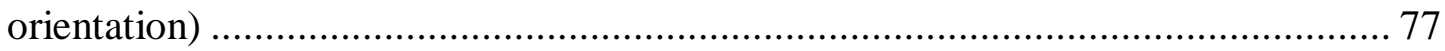

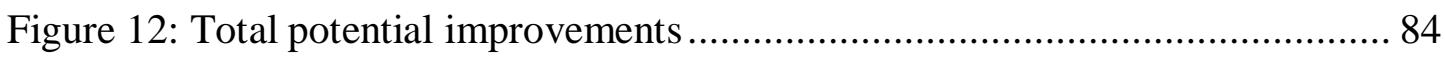

Figure 12: Regions of the COREDE.............................................................. 112

Figure 13: COREDE Alto Jacuí and municipalities ........................................... 113 


\section{List of Acronyms}

TE - Technical Efficiency

MTE - Mean Technical Efficiency

AMTE - Average Mean Technical Efficiency

DMU - Decision Making Units

CRS - Constant Returns to Scale

IRS - Increasing Returns to Scale

CCR - Constant Returns to Scale

VRS - Variable Returns to Scale

DRS - Decreasing Returns to Scale

BCC - Variable Returns to Scale

OLS - Ordinary Least Squares

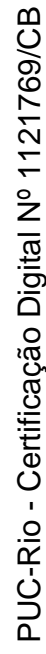

CD - Cobb-Douglas

TL - Translog

$\mathrm{P}$ - Parametric

NP - Non-Parametric

S - Stochastic

D - Deterministic

DEA - Data Envelopment Analysis

PSTO - Parametric Stochastic

OF - Cobb-Douglas or Translog

CS - Cross-sectional

VAR - Number of explanatory variables

LIC - Low-income Country

LMIC - Lower Middle-income Country

UMIC - Upper-income Country

HICS - High-income Country

NAMR - North America (United States and Canada)

AFRI - Africa

LTCR - Latin America or the Caribbean

EAST - Eastern Europe

EDU - Education 
MSYS - Milking System

INS - Insemination

OBREED - Other Breed

SER - Services

A - Land

AH - Animal Health

AI - Area Irrigated

B - Butterfat

$\mathrm{C}-\mathrm{Cow}$

Ca - Cattle or animal

$\mathrm{Cr}-\mathrm{Crop}$

De - Depreciation

E - Equipment

En - Energy

O $\quad$ Env - Environmental

$\mathrm{Fe}-$ Feed

Fer - Fertilizer

Fo - Fodder

IC - Intermediate Consuption

II - Intermediate Inputs

K - Capital

L - Labour

Li - Livestock

M - Material

M - Milk

$\mathrm{O}$ - Others

OC - Other Costs

OI - Others Incomes

$\mathrm{Ou}$ - Others Outputs

Q - Quota

R - Rent

Se - Seed

W - Water 


\section{1}

\section{Introduction}

Since the 1960s the worldwide production of milk has been in continuous growth. Production reached 719 million tonnes in 2010, with an average annual growth rate of $2.7 \%$ in the period $2000-2010$ (FAO, 2013). The socio-economic importance of the dairy sector has resulted in persistent government intervention over several decades (Rivas, 2003). Despite its economic and social relevance, concerns with the increase of the world's dairy production and derived income are constant. The debate is governed by the search for increased efficiency. It yielded a substantial number of studies showing that dairy farmers could improve their performance and earnings (Bravo-Ureta \& Rieger, 1991; Tauer, 1993; Heshmati \& Kumbhakar, 1994; Fraser \& Cordina, 1999).

Understanding the factors affecting Technical Efficiency (TE) is vital to improve efficiency and performance. Farrell (1957) first developed the notion of TE. From the output perspective, TE measures the potential increase in output, keeping the inputs constant. From the input perspective, TE measures the ability of the firms to produce a given output using the smallest set of inputs. Measuring efficiency and the potential sources of inefficiency are, therefore, important because they are the first step in a process that may lead to substantial resource savings. These resource savings have important implications for both policy formulation and farm management. Producers benefit directly from gains in efficiency because efficient farms tend to generate higher incomes and thus have a better chance of surviving and staying in business (Bravo-Ureta \& Rieger, 1991; Moreira López, 2006). On the other hand, policymakers could use this knowledge to identify and target public interventions to improve productivity and the competitiveness of dairy farms (Bravo-Ureta \& Rieger, 1991; Solís et al., 2009; Chidmi et al., 2010).

The definition and measurement of TE became increasingly popular, as evidenced in the literature reviews of Battese (1992) and Bravo-Ureta \& Pinheiro (1993). These authors have considered selected articles in order to derive general 
conclusions about the range of methodological and empirical frontier studies. Other authors also reviewed the application of different production frontiers functions in agriculture, but few studies focused specifically on dairy farms as this doctoral thesis does. The study by Bravo-Ureta et al. (2007) applied metaregression of TE measures for all agricultural activities to 167 farm-level studies worldwide. Rivas (2003) and Moreira López (2006) applied a meta-regression analysis to describe the behaviour of TE for a limited group of dairy farm studies.

Different factors and methodologies to measure TE can produce contradictory results. Resti (2000) simulated the application of parametric and non-parametric techniques, concluding that there is no clear advantage of one method over the other. However, empirical studies by Sharma et al. (1999) and Solís (2005) have shown that the selection of a specific methodology can affect TE measure. Several authors have discussed the advantages and limitations of different methodological approaches (Coelli, 1995; Alvarez \& Orea, 2002). Geographical location (Hallam \& Machado, 1996; Álvarez \& González, 1999) and farm size (Kumbhakar et al., 1989; Areal et al., 2012) are other factors that can affect the TE and despite the lack of general agreement, one might hypothesize that dairy farms with high levels of TE tend to be higher in a favourable context. Although the choice of the methodology to measure TE can have a direct impact on the results, there is no agreement as to the most appropriate methodology for a given situation (Olesen et al., 1996), which remains a matter of ongoing debate (Bravo-Ureta et al., 2007).

This thesis addresses this gap by presenting a research synthesis on TE in dairy farms and by offering an empirical study aiming at measuring and understanding the factors affecting the TE in dairy farms of selected municipalities in the South of Brazil. The goal of the research synthesis was to integrate the findings of existing studies about TE in dairy farms through a systematic literature review, offering a research synthesis framework as a structuring tool to assemble TE descriptors from the extant literature. In addition, a meta-regression analysis of 103 published papers totalling 531 distributions of TE in dairy farms is applied to analysing the effects of different methodologies and study-specific characteristics on Mean TE (MTE). The empirical study tests 
hypothesis that emerged from the research synthesis, which is part of the scope of the Thesis second goal.

The structure of the Thesis is displayed in Figure 1 and reads as follows. After this introduction chapter, definitions and measurement techniques of TE are defined in Chapter 2. The research methods of the meta-synthesis, metaregression and the empirical study are presented in Chapter 3. The framework, determinants of $\mathrm{TE}$, variables and measurement techniques more used, propositions and hypothesis are laid and discussed in Chapter 4. The results of empirical investigation of TE in dairy farms of selected municipalities in the South of Brazil are presented and discussed in Chapter 5. Finally, conclusions are offered in Chapter 6.

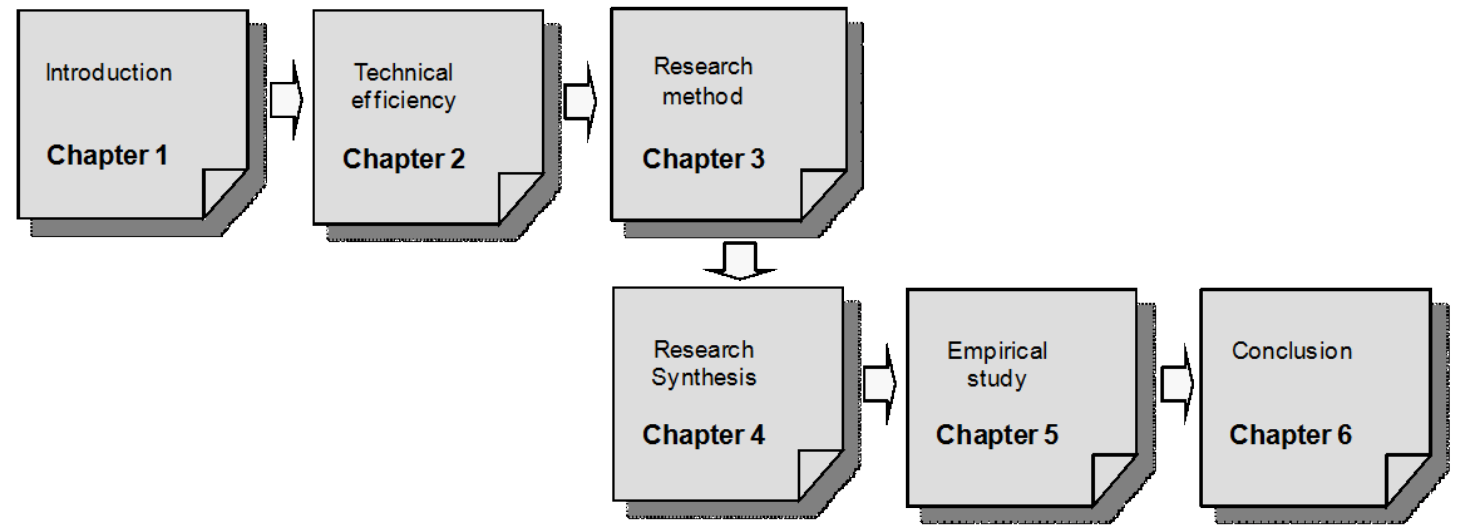

Figure 1: Structure of the Thesis 


\section{2}

\section{Technical efficiency: definitions and measurement techniques}

TE was defined by Farrell (1957) in two ways: i) the ability of firms to produce the maximum feasible output with a given bundle of inputs (outputoriented) or ii) the ability of firms to use minimum inputs to produce a given level of outputs (input-oriented). The basic approach to measure level efficiency is estimating a frontier that envelops all the input/output data with those observations lying on the frontier being described as technically efficient. Any firm or farm that lies below the frontier is considered to be inefficient (Fraser \& Cordina, 1999, p. 269).

Figure 2 depicts six units of analysis (e.g. firms, farms) producing a single output (vertical axis) using a single input (horizontal axis). The solid line connecting units A, B and C can be interpreted as an 'efficiency frontier'. The unit D consumes the same level of input as C, but produces a lower level of output. In this case, unit $\mathrm{C}$ is a benchmark for $\mathrm{D}$, which means unit $\mathrm{D}$ is designated inefficient, with the amount of inefficiency shown by the vertical arrow from $\mathrm{D}$ to C. Similarly, the efficiency of units $\mathrm{E}$ and $\mathrm{F}$ is measured vertically or horizontally with respect to efficient units (Rouse et al., 2010).

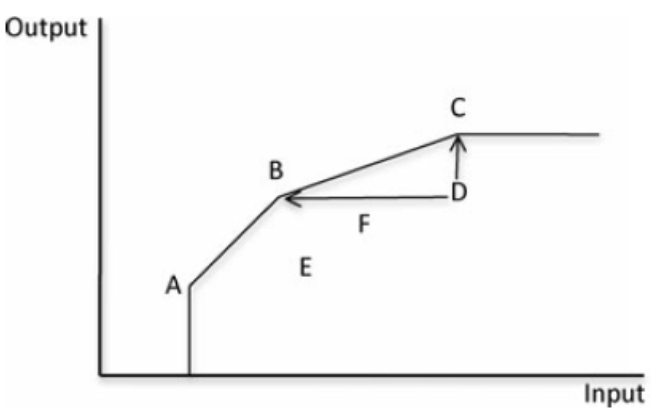

Figure 2: Single input-output process

Source: Rouse et al. (2010, p. 166) 
The measurement of efficiency dates back to over 60 years, to a time when Debreu (1951) and Koopmans (1951) implicitly addressed this issue in the economic literature. Farrell (1957) was the first to build upon this work and explicitly introduced the notion of efficiency measurement. Since Farrell's work, a large number of frontier models have been proposed to improve the measurement of TE. These models are presented next.

\section{1}

\section{Non-parametric and parametric models}

The types of frontier models are depicted in Figure 3. They can be nonparametric and parametric. Non-parametric models are subdivided in deterministic and stochastic. Contrary to non-parametric frontiers models, parametric frontiers requires predetermined functional forms (e.g., Cobb-Douglas, Translog, Transcendental) and error distributions (e.g., half-normal, truncated normal, exponential, gamma) (Coelli, 1995; Haghiri et al., 2004). The Cobb-Douglas functional form has been most commonly used in the empirical estimation of frontier models and its most attractive feature is its simplicity. A logarithmic transformation (Translog) provides a model which is linear in the logs of the inputs and imposes no restrictions upon returns to scale or substitution possibilities (Coelli, 1995).

Furthermore, it is possible to use a statistical method or mathematical programming to estimate the frontier (Moreira López, 2006). For both types, estimation procedures can be deterministic or stochastic. Deterministic models assume that any deviation from the frontier is due to inefficiency, while probabilistic models are compound by an error term accounting for inefficiency and random noise (Greene, 1993; Coelli, 1995). 


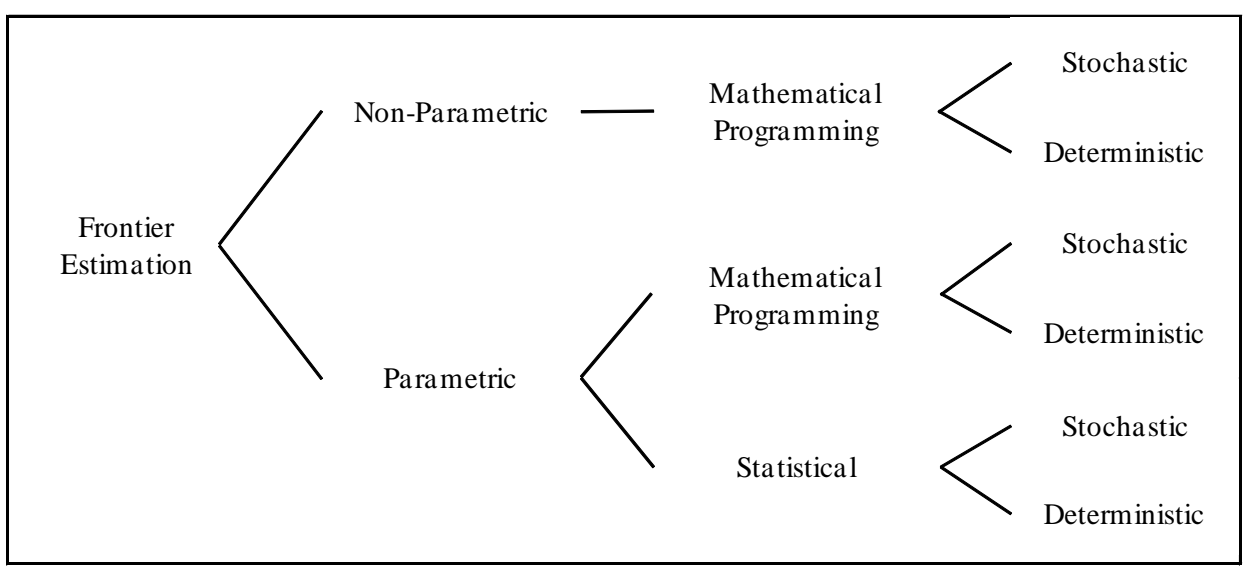

Figure 3: A summary view of frontier models Source: Adapted from Esteban Garcia \& Coll Serrano (2003)

"The advantages associated with the non-parametric approach are that no arbitrary assumptions about the technology are necessary to calculate efficiency and that the number of inputs to be included in the model is not limited by statistical concerns” (Rivas, 2003, p. 37). Attractiveness of non-parametric models was boosted by the appearance of data envelopment analysis - DEA, developed by Charnes et al. (1978).

A disadvantage of the non-parametric approach is its inability to separate out the effects of measurement errors from inefficiency. Thus, all deviation from the frontier is attributable to inefficiency. As in non-parametric models, deterministic parametric models assume that all deviation from the frontier is due to inefficiency (Greene, 1993; Coelli, 1995). This may be acceptable as long as efficiency measures are interpreted as a relative rather than an absolute measure (Tauer, 1993). The deterministic frontier production function can be expressed as, equation (1):

$$
Y_{i}=G(X, \beta) \exp (-u)
$$

where $Y_{i}$ is the output of farm $i$; $X$ is the vector of independent variables; $\beta$ is a vector of parameters to be estimated; and $u$ is a non-negative component that represents technical inefficiency relative to the deterministic frontier. The introduction of the one-sided error term $(-u)$ ensures that all observations fall on or below the estimated production frontier.

On the other hand, the stochastic frontier production model incorporates an error term with two random components, equation (2): a traditional two-sided 
random error and a one-sided component representing the degree of technical inefficiency, $v_{i}$ and $u_{i}$ (Greene, 1993; Coelli, 1995). These models were developed by Aigner et al. (1977) and Meeusen \& Van den Broeck (1977) for cross-sectional data.

$$
Y_{i}=g(X, B) \exp \left(v_{i}-u_{i}\right)
$$

Frontier models can use cross-sectional or panel data. The second would be more appealing because it can overcome several limitations that exist in increment cross-sectional studies (Schmidt \& Sickles, 1984; Battese \& Coelli, 1992). For example, a major limitation of cross-sectional studies is that it is not possible to separate the impact of specifics of a given year from efficiency, which is an indicator of the farmer's managerial abilities for that specific year (Lovell, 1996). Greene (1993) and Lovell (1996) indicated that parameter estimates from panel data makes a more efficient use of the available information.

Despite the increasing use of different methodologies and of the steady and significant advances in the frontier literature over the past three decades, many methodological questions remain. On the one hand, some authors have discussed the advantages (e.g. not being limited by a priori functional forms -NP, frontier model incorporates two components: error term and inefficiency -P) and limitations (e.g. specification of a predetermined functional forms -P, all deviation from the frontier is due to inefficiency - NP) of the different methodological approaches to measure efficiency (Coelli, 1995; Ahmad \& Bravo-Ureta, 1996; Alvarez \& Orea, 2002).

On the other hand, there are many studies that evaluate the effect of different methodologies and study-specific characteristics on TE (Tauer \& Belbase, 1987; Haghiri et al., 2004; Areal et al., 2012; Van Der Voort et al., 2014). Some authors defend the two-stage procedure (Banker \& Natarajan, 2008; McDonald, 2009) and other authors (Kumbhakar et al., 1991; Battese \& Coelli, 1995) criticise this approach by arguing that "the factors should be incorporated directly in the estimation of the production frontier because such factors may have a direct impact on efficiency" (Sharma et al., 1999, p. 26).

Despite this criticism, the two-step procedure is still quite popular in investigating the relationship between efficiency and specific variables. Because 
the two-step procedure is equally applicable to both approaches, we adopt this approach to analyse the role of factors in the TE level of dairy farms in municipalities of the South of Brazil. A two-stage study first obtains efficiency level through DEA or parametric stochastic frontier and then correlates them with various factors either by Tobit regression analysis, ordinary least squares (OLS), maximum likelihood estimation (MLE) or analysis of variance (ANOVA) tests (Sharma et al., 1999; Liu et al., 2013). Fried et al. (2002), Simar \& Wilson (2007), Banker \& Natarajan (2008) and McDonald (2009) are others studies on two-stage analysis.

Given that the efficiency scores are bounded between 0 and 1 , it is pertinent to prefer the Tobit model in cases where the dependent variable is doubly censored (Greene, 2002). Among others this method has also been employed by Hansson (2007), Bravo-Ureta et al. (2007), Chang \& Mishra (2011), Shortall \& Barnes (2013). The parameters of the Tobit model present only the qualitative relationship between the exogenous variables and TE. The effect of the exogenous determinants on TE can be better understood by calculating the marginal effects that measure an additional change in the exogenous variables on the estimated efficiency score (Greene, 2008; Chang \& Mishra, 2011). McDonald (2009) also considers the Tobit model with Marginal Effects.

An alternative to Ordinary Least Square (OLS) could be Tobit Two-limit Model. This "estimation will give inconsistent, inefficient and biased estimates because it underestimates the true effect of the parameters by reducing the slope" (Bhatt \& Bhat, 2014, p. 34). According to Moreira López (2006), the metaanalysis literature focusing on TE in the agricultural sector reports similar results for the Tobit and OLS procedures. Hoff (2006) reports that OLS regression can be used with little difference in results compared with a Tobit analysis. Despite similar patterns, the Tobit approach is the most appropriate, given the characteristics of the data used in this analysis (Bravo-Ureta et al., 2007).

The two-stage study is used in the empirical Section (Chapter 5) of this Thesis. First obtains efficiency level through DEA (see Subsection 2.2) and then correlates them with various factors from the regression analysis. In addition of the advantages of the NP method, in $90.2 \%$ of the NP studies presented in the 
Section 4 (Research Synthesis), DEA was used. Then, reporting similar results, we used the OLS and Tobit model with marginal effects in the empirical study.

\section{2}

\section{Data envelopment analysis}

Data envelopment analysis (DEA) is a non-parametric method that allows multi-input and multi-output production systems to be benchmarked by constructing a piecewise linear surface over observed data points (Charnes et al., 1978). The use of multiple inputs and outputs is an appeal of DEA, because it provides quantitative insight to the form and magnitude of the adjustments needed to improve the performance of the farms (Fraser \& Cordina, 1999).

According to Rouse et al. (2010, p. 166) "DEA is a mathematical optimisation model used to measure the efficiency of organizations or parts of organizations (referred to as decision-making units - DMUs) that have similar attributes". The measure of TE is specific to the sample; that is, a DMU is $100 \%$ efficient if there is no evidence of inefficiency when compared to all other DMUs (see Figure 4, DMUs 7 and 83). Farms that lie below this frontier (e. g. DMU 62, Figure 4) are designated inefficient (Rouse et al., 2010). "Farrell argued that this is more appropriate as it compares a farm's performance with the best actually achieved rather than with some unattainable ideal” (Fraser \& Cordina, 1999, p. 269). 


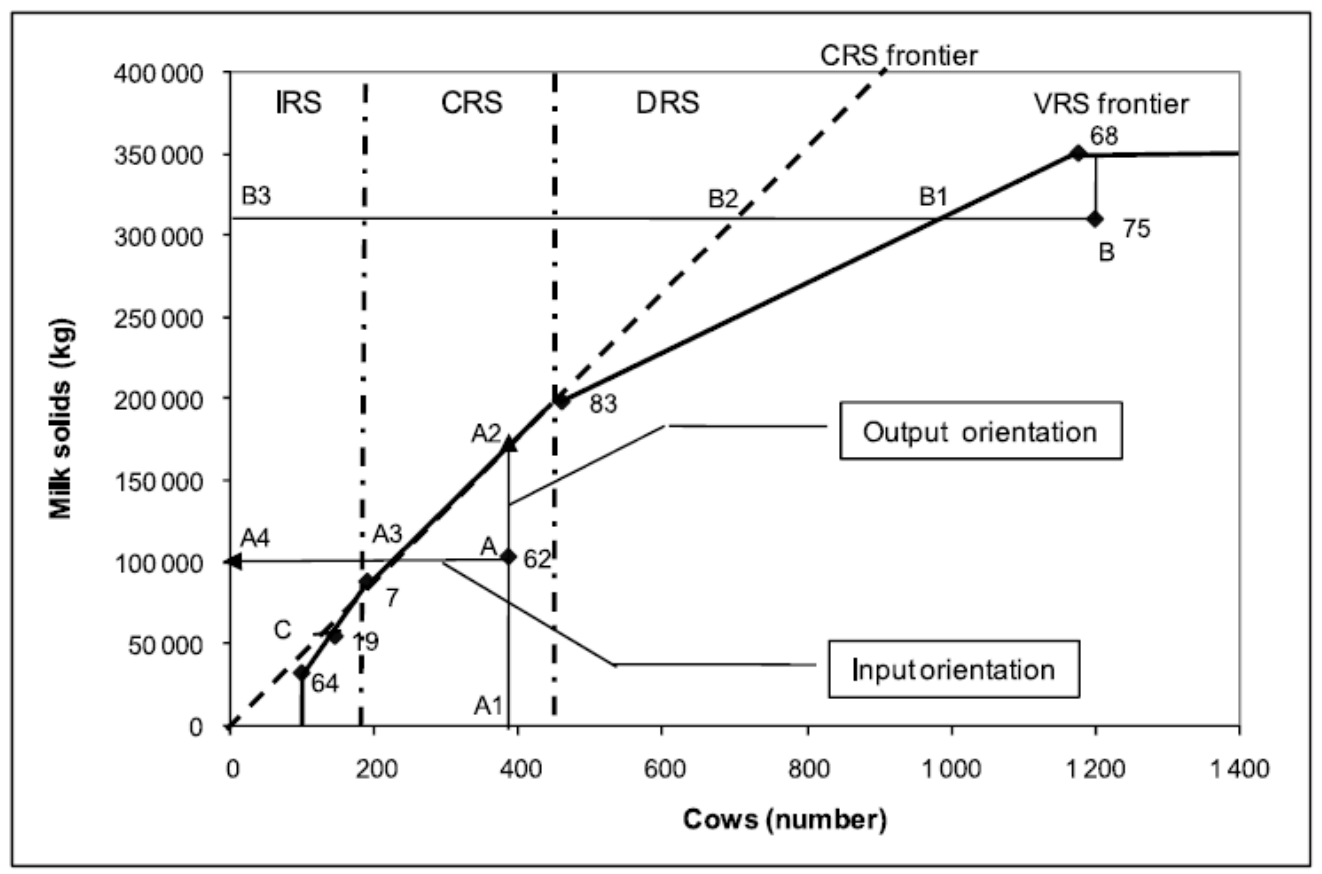

Figure 4: Constant and variable returns to scale Source: Rouse et al. (2010, p. 167)

Fully efficient DMUs form a best practice production frontier and are 'benchmark peers' for inefficient DMUs" (Rouse et al., 2010, p. 166). "These inefficient farms will be benchmarked to a proportion of each benchmark farm (for example, 0.5 of Farm 7) or a 'combination' of both farms (for example, 0.4 of Farm 7 and 0.6 of Farm 83)" (Rouse et al., 2010, p. 167). For example, for the DMU 62, the vertical arrow from A to A2 measures inefficiency under an output orientation (maximum output with a given bundle of inputs) and represents the additional milk solids achievable given its current number of cows. The horizontal arrow from A to A3 measures inefficiency under an input orientation (minimum inputs to produce a given level of outputs) and represents the number of cows to reduce given that level of milk solids (Rouse et al., 2010). So the input orientated measures the input quantities changes without changing the output quantities. The assumed objective is "to reduce the input quantities as much as possible, without changing the output quantities” (Kovacs \& Emvalomatis, 2011, p. 123).

Figure 4 shows two alternative frontiers: constant returns to scale - CRS (represented by the straight broken line emanating from the origin) and variable returns to scale - VRS (the frontier is represented by the solid line and consists of three parts: IRS, CRS, and DRS). Technical input and output efficiencies are different conceptually, but the scores are the same if constant returns to scale are 
assumed or actually the case (Hansson, 2007; Hansson \& Öhlmér, 2008). "CRS is a strong assumption. In practice, production processes often do not scale perfectly, showing instead increasing returns to scale (IRS) and decreasing returns to scale (DRS) at various points. Non-constant returns to scale are referred to as VRS" (Rouse et al., 2010, p. 167).

If CRS (DMUs 7 and 83) are assumed, means that a 10\% increase in the number of cows will produce a $10 \%$ increase in milk solids, for example (Rouse et al., 2010). CRS can be applied when all farms are operating at an optimal scale; that is, they do not need to change size to realize efficiencies. But in practise, due to imperfect competition, government regulations, etc., farms are often not operating at an optimal scale. In this case it is more useful to apply VRS which isolates the scale effect from overall efficiency change (Barnes et al., 2011; Keizer \& Emvalomatis, 2014). If VRS are assumed, means under IRS (DMUs 19 and 64), a $10 \%$ increase in the number of cows leads to a more than $10 \%$ increase in milk solids. Under DRS (DMU 68), as shown by the right part of the VRS frontier, a $10 \%$ increase in the number of cows generates a less than $10 \%$ increase in milk solids (Rouse et al., 2010). "The main advantage of the VRS model is that scale-inefficient farms are only compared with efficient farms of a similar size" (Barnes et al., 2011, p. 5450). Consequently, based in these differences, "farms that are inefficient under CRS can have higher estimated TE scores under VRS. Since VRS takes size into account, farms compared to other farms of similar size and hence may not have the same benchmarks as under CRS" (Rouse et al., 2010, p. 167).

There are several reasons for using DEA analysis to assess TE. Firstly, DEA is based upon linear programming, an analytical tool that is familiar to many agriculturalists. For example, the DEA method has been applied to estimate the efficiency score in agriculture and in dairy farms (Bravo-Ureta et al., 2007; D’Haese et al., 2009). In addition to be a more familiar technique for agriculturalists than other statistical methods, the recent development of several DEA software programs has made this technique more accessible to researchers. Secondly, the type of information generated by DEA is "detailed in relation to input use and the optimal factor mix, the identification of efficient farms within a sample and which farms are of most importance when it comes to benchmarking" 
(Fraser \& Cordina, 1999, p. 268). DEA has been used extensively for benchmarking performance (Jaforullah \& Whiteman, 1999).

Thirdly, "in the last couple of years there has been a large increase in available computer software with which to undertake DEA. This software is easy to use and the results that are generated are easy to understand" (Fraser \& Cordina, 1999, p. 268). Finally, DEA does not require a parametric specification of a functional form to form the frontier (Coelli, 1995; Haghiri et al., 2004). "This means that unnecessary restrictions about functional form that can impinge upon the analysis and distort efficiency measures are avoided.” (Fraser \& Cordina, 1999, p. 268). The next chapter presents the research methods of the metasynthesis, meta-regression and the empirical study. 


\section{3}

\section{Research Method}

This chapter presents the research methods adopted for the research synthesis and for the empirical study. A brief synthesis of the Thesis's organization and methods closes the chapter.

\section{1}

\section{Research synthesis}

The research method adopted to achieve the first goal of the thesis is the research synthesis. This method encapsulates previous research findings on a specific subject area by drawing overall conclusions from many separate investigations that address related or identical hypotheses (Cooper, 2010). Research synthesis focuses "on empirical studies and seek to summarize past research by drawing overall conclusions from many separate investigations that address related or identical hypotheses” (Cooper, 2010, p. 4). It facilitates the identification, evaluation, and interpretation of studies in the given area by examining existing concepts, practices, and theories and then summarizing the current state of the art of the topic, providing research propositions and guidance for future studies to address existing knowledge gaps (Rowley \& Slack, 2004). This Section presents next the main steps for the research synthesis.

\subsection{1}

\section{Sample selection}

A six-step process is used to select the studies included in the review, inspired on Thomé et al. (2012; 2014). Seven databases were selected in the first step. Together, they host the majority of scientific journals covering the research subject: Agecon Search, Ebsco, Emerald, Springerlink, Scielo, Science Direct and Wiley. 
In the second step, the phrases "technical efficiency in dairy farms" and "technical efficiency and milk production" are adapted to the search engines of each database and applied to titles, abstracts and keywords, with no limitation on publication dates. The second phrase was used, because particularly in Brazil the term "milk production" is used. This choice follows Cooper's (2010) recommendations for initial research synthesis, aiming to select keywords for search that are sufficiently broad to avoid artificially limiting initial results but still providing limitations to avoid undesirable references to appear in the search. It resulted in the selection of 206 papers.

In the third step, criteria to exclude papers were applied, adapted from Lipsey \& Wilson (2001). Threats to validity of primary research were regrouped in broad categories and papers were excluded as follows: (i) duplicated papers; (ii) veterinary research to improve milk production or experiments on animal reproduction; (iii) articles dealing with the combined efficiency of agricultural production and milk; and (iv) methodological basis inadequately explained (only superficial analysis of efficiencies).

The fourth step consists on the review of selected abstracts. This review of abstracts applied the exclusion criteria of step 3, resulting in 134 papers selected for full-text reading (step 5). Additional papers were excluded after full-text reading, based on the exclusion criteria of step 3, resulting in the selection of 90 papers in the fifth step.

In step six, the references cited in the selected papers were manually reviewed, resulting in the inclusion of 13 new studies, totalling 103 papers for the final selection. Figure 5 presents a summary of the numbers of papers selected in each of these steps by bibliographic database. 


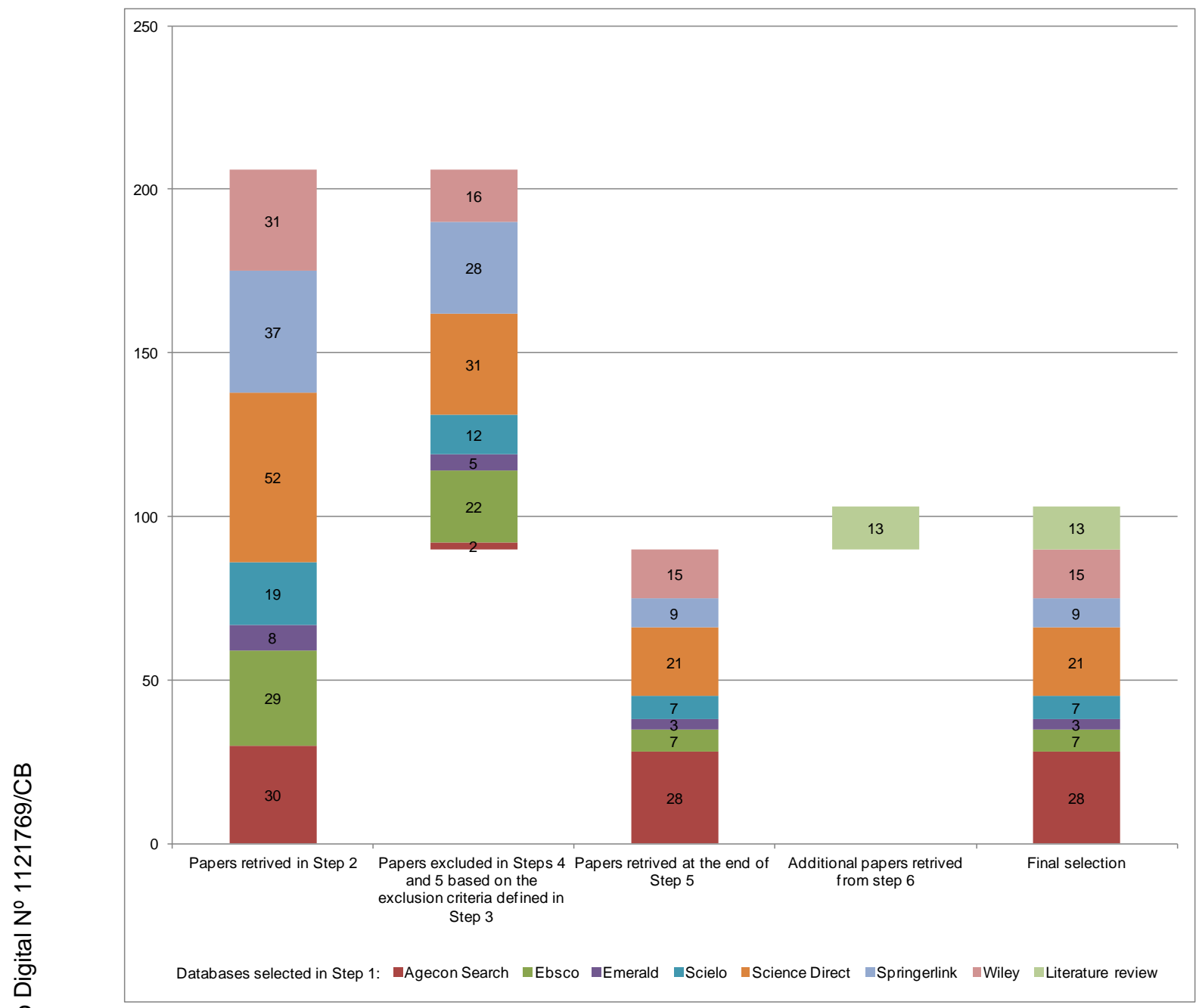

Figure 5: Results of the literature review by selection steps and database

\subsection{2}

\section{Content analysis}

The analysis and interpretation in content analysis is inspired in Mayring's (2000) guidelines, as follows: (i) material collection (see Subsection 3.1.1); (ii) descriptive analysis, (iii) category selection, and (iv) material evaluation, as portrayed in the logical framework and analysis reported in Subsection 4.2 MetaSynthesis.

The pilot analysis done initially with 10 papers retrieved. A formative reliability check was conducted during the coding of the first studies (25\%), in accordance with Neuendorf's (2002) recommendations. A preliminary logical framework was developed from the emerging categories. First, categories for context and determinants of TE were developed: location, age, education, land, 
cows, farm size, feeding practices, animal health, services, infrastructure and technology, finance, programs and marketing, information management, investment and costs (Table 3). Then, elements to the measurement of TE were identified: inputs and outputs variables, measurement techniques. From the reading of the other papers, others categories and elements were included and the framework was refined.

The final version framework is presented in Figure 8. The inputs and outputs variables and measurement techniques were identified in each of the studies and are presented later in Table 4.

\subsection{3}

\section{Meta-regression analysis}

This subsection presents the meta-regression analysis for secondary data. For the secondary data (103 studies selected) analysis, meta-regression was applied to analyse the effects of different methodologies and study-specific characteristics on Mean TE (using four models).

A meta-regression analysis was applied to the distributions from the sample of 103 papers. Meta-analysis is an approach that uses published empirical estimates of some indicator and attempts to explain the variation of these estimates based on differences cross studies (Stanley \& Jarrell, 1989). The procedures employed in meta-analysis permit quantitative reviews and syntheses of studies examining similar research issues (Rivas, 2003; Moreira López, 2006; Bravo-Ureta et al., 2007; Moreira López \& Bravo-Ureta, 2009). In this case, meta-regression was applied to the different methodologies and study specific characteristics that may affect mean TE. Results from a meta-regression analysis of 103 published papers totalling 531 TE distributions in dairy farms worldwide are discussed.

The hypothesis of this study (see Subsection 4.3) are that the variation in the MTE reported in the literature can be explained by the attributes of the studies, including estimation technique, functional form, dimensionality, geographical region and income level. Four meta-regression models were estimated. Model (1) includes functional form, sample size, dimensionality and estimation technique. Model (2) introduces three dummies to account for the effect of income level on 
MTE. Model (3) includes a set of five dummy variables to capture potential regional effects, and Model (4) includes two variables to capture potential farm size (herd and land area) effects.

Model I:

$$
M T E=f(P S T O, N P, C D, O F, C S, V A R)
$$

where:

MTE is mean TE, as reported in the studies;

PSTO is a dummy variable equal to 1 if the model is a parametric stochastic frontier and 0 otherwise;

NP is a dummy variable equal to 1 if the estimation was performed using nonparametric techniques and 0 otherwise;

$\mathrm{CD}$ is a dummy variable equals to 1 if the Cobb-Douglas functional form is used and 0 otherwise;

OF is a dummy variable equals to 1 if a functional form other than Cobb-Douglas or translog is used and 0 otherwise;

CS is a dummy variable equals to 1 if the data is cross-sectional and 0 otherwise; VAR is the number of explanatory variables included in the study.

Model II:

$M T E=f(P S T O, N P, C D, O F, C S, V A R, L I C, L M I C, U M I C)$

where:

LIC is a dummy variable equals to 1 for low-income countries and 0 otherwise;

LMIC is dummy variable equals to 1 for lower middle-income countries and 0 otherwise;

UMIC is dummy variable that takes the value of 1 for upper-middle income countries and 0 otherwise.

PSTO, NP, CD, OF, CS, VAR are as defined in equation (1).

The excluded category in this case is the high-income country studies, or HICs.

Model III:

MTE

$=f(P S T O, N P, C D, O F, C S, V A R, A S I A, N A M R, A F R I, L T C R, E A S T)$

where:

ASIA is a dummy variable equals to 1 if the study used data for that part of the world and 0 otherwise;

NAMR is a dummy variable equals to 1 if the data comes from North America (United States and Canada) and 0 otherwise; 
AFRI is a dummy variable equals to 1 if the study used data from Africa and 0 otherwise;

LTCR is a dummy variable equals to 1 if the study used data from Latin America or the Caribbean and 0 otherwise;

EAST is a dummy variable equal to 1 if the study used data from Eastern Europe and 0 otherwise.

The omitted region is Western Europe and Oceania.

PSTO, NP, CD, OF, CS, VAR are as defined in equation (1).

Model IV:

MTE

$=f(P S T O, N P, C D, O F, C S, V A R, C O W, L A N D)$

where:

COW is the average number of cows;

LAND is the average number of hectares per farm;

A variant of Model IV is the ratio COW/LAND.

PSTO, NP, CD, OF, CS, VAR are as defined in equation (1).

Models I, II, III and IV are estimated using the Tobit and OLS procedures, considering the Marginal Effects. STATA version 11 software was used. The four models presented were elaborated from the studies of Rivas (2003), Moreira López (2006) and Bravo-Ureta et al. (2007). Then, the results of four studies were compared (Table 10). A premise assumed in this study is that the different years of research will not affect the results significantly. Although, this assumption becomes a limitation of the study, it is also assumed in the literature by Moreira López (2006) and Bravo-Ureta et al. (2007).

\section{2}

\section{Empirical study}

This subsection provides the method of the empirical study: source of data - survey, DEA model and regression analysis. 


\section{Survey}

The empirical study used primary data from a survey undertaken in 2010 in 14 municipalities of the State of Rio Grande do Sul / Brazil - Regional Council Development of Alto Jacuí (COREDE Alto Jacuí) (see Annex 1 - Figure 12 and Figure 13). This state is considered the second national producer of milk, surpassed only by Minas Gerais, and contributes with about $12 \%$ of national production, or 3.879.455 million litters in 2011 (IBGE, 2011). The major producing regions occupy the northern portions and northeast of the state, including COREDE Alto Jacuí (SEPLAN-RS, 2015).

In addition, dairy farming was identified as a potential economic activity for all municipalities of COREDE Alto Jacuí during the development of the Strategic Planning of Regional Development (Corrêa et al., 2010). As a result, an array of opportunities, threats, strengths and weaknesses was debated and further developed. To address this context, two additional projects were developed: (1) diagnosis of dairy production units of Municipalities of COREDE Alto Jacuí, and (2) efficiency indicators study in dairy production units of Municipalities of COREDE Alto Jacuí. The two projects were submitted and approved in the program support for scientific and technological regional development in the state of Rio Grande do Sul - PROCOREDES VII - PROCESS of the PARTICIPATION POPULAR in the region Alto Jacuí, under the Notice No. 011/2010 FAPERGS. These projects were realized in partnership with University of Cruz Alta (UNICRUZ) and were attended by teachers and scholars. The author of this thesis was the coordinator of one of them and participated as a senior researcher in the other.

The goals of the projects were: (1) to provide a diagnostic of the milk production units of the municipalities of COREDE Alto Jacuí - RS from a social, economic, productive and environmental points of view, and (2) to evaluate the efficiency and inefficiency of milk production units of the municipalities of COREDE Alto Jacuí. Therefore, the questionnaire was drawn up with the participation of teachers from various areas of knowledge of the University of Cruz Alta: veterinary medicine, economics, geography, accounting, mathematics, animal husbandry, rural development and extension. The questionnaire (see 
Annex 2) captured a good deal of information on different factors and activities relevant to dairy farming: household composition/ labour availability, farm activities and facilities, livestock inventory, milk production, livestock health services, feeds, breeding, and household welfare.

The sample was random to 14 municipalities of the Regional Council Development of Alto Jacuí. A sample of the 253 dairy farms was considered to be reasonably representative for the region. It is worth mentioning that 37 of the studies analysed in the next Chapter of this Thesis considered a sample smaller than this one. Further methodological details on the projects are provided in Mareth \& Paim (2012) and Lorenzoni et al. (2012). Table 1 describes the main characteristics of the farms in the sample.

Table 1: Overview of inputs, outputs used, and farmer characteristics $(n=253)$

\begin{tabular}{|c|c|c|c|}
\hline SD & Minimum & Maximum & CV (\%) \\
\hline \multicolumn{4}{|c|}{ Inputs } \\
\hline 41 & 5 & 310 & 98 \\
\hline 63848 & 740 & 883500 & 258 \\
\hline 7981 & 40 & 60000 & 135 \\
\hline 133 & 5 & 1330 & 203 \\
\hline \multicolumn{4}{|c|}{ Output } \\
\hline 209041 & 12167 & 1752000 & 121 \\
\hline 0,026 & 0,010 & 0,215 & 131 \\
\hline \multicolumn{4}{|c|}{ Farmer characteristic } \\
\hline \multicolumn{2}{|c|}{ Dutch breed, $\%$ of total breed } & 70 & \\
\hline \multicolumn{2}{|c|}{ Others breeds, $\%$ of total breed } & 30 & \\
\hline \multicolumn{2}{|c|}{ Insemination } & 87 & \\
\hline \multicolumn{2}{|c|}{ Milking system } & 53 & \\
\hline \multicolumn{2}{|c|}{ Services } & 32 & \\
\hline \multicolumn{4}{|c|}{ Education level } \\
\hline \multicolumn{2}{|c|}{ EDU1 the farmer has less than high school education } & 82 & \\
\hline \multicolumn{2}{|c|}{ EDU2 the farmer finished high school } & 16 & \\
\hline \multicolumn{2}{|c|}{ EDU3 the farmer has higher education } & 2 & \\
\hline
\end{tabular}

* \% of total sample

Dairy farms had on average 42 cows, the size of the smallest farm in the sample was 5 cows and of the largest farm were 310 cows. Their mean surface area was 65 ha, the size of the smallest farm in the sample was 5 ha and that of the largest farm was 1330 ha. Several farmers had less than high school education (82\%), whereas some had a superior level degree (2\%). The descriptors and variation coefficients show that the sample reflected the large diversity of dairy 
farms also in terms of size. The next subsection presents the DEA model used in the empirical study.

\section{2 .2}

\section{DEA model}

Most inputs to the process of measurement of TE are concentrated on aspects pertaining to labour (L), land (A), capital (K), feed (Fe) and cow (C), based in the 103 previous studies (see Table 4, chapter 4). Veterinary, pasture and breeding prevail among inputs related to animal health. According to Rouse et al. (2010, p. 170) "there is little divergence in terms of the specification of inputs and outputs in the DEA literature on dairy farm efficiency". The number of cows, land area, labour, feed, fertilizer and capital (building and equipment) are the most commonly used inputs. "Energy, irrigation, veterinary expenses and other expenses are also considered in some studies" (Rouse et al., 2010, p. 170). Furthermore, there are several studies that consider only milk yield as output. Based on the 103 previous studies, 55 (53.4\%) papers considered only milk (production or income). These studies are based on farms where dairy activity is highly dominant, such as Ahmad \& Bravo-Ureta (1996), Fraser \& Cordina (1999), Cabrera et al. (2010) and Rouse et al. (2010).

Based on the literature and on the data available from the survey, the empirical model in this study included the output variables: milk production and bonus (farmers receive bonus by quality and quantity of milk production); and, input variables: cow, feed, labour and land. Descriptive statistics of inputs and outputs used in the analysis is presented in Table 1.

The empirical study was developed in a two-stage approach (Hansson, 2007; Hansson \& Öhlmér, 2008; Chang \& Mishra, 2011; Luik et al., 2014). In the first stage, a DEA model was used to estimate the TE level of the dairy farms in selected municipalities of the South of Brazil. Then using primary data, regression models are used to test the hypotheses that emerged from the research synthesis.

TE scores were calculated using DEA. As previously discussed, in addition to the advantages of the NP method, DEA was used in $90.2 \%$ of the 41 
NP studies presented in the chapter 4 (Research Synthesis). The DEA models used in these studies are Constant Returns to Scale - CCR and Variable Returns to Scale - BCC (43\%), BCC (32\%) and CCR (11\%). The orientation ranking of the DEA models is input (65\%), output (27\%), input and output (8\%). For the empirical study, DMU is each dairy farm and for each one the benchmark analysis was realized (see Subsection 5.2). CCR and BCC models with input and output oriented were used to provide additional insights on dairy farming efficiency (see Subsection 5.1). The computer program Frontier Analyst version 4.0 was used to calculate the efficiency scores.

\section{2 .3}

\section{Regression analysis}

From the results of DEA model, two regression models are estimated to test the hypotheses that emerged from the research synthesis (Chapter 4). The hypothesis are that the variation in the MTE of the dairy farms can be explained by attributes of the studies, including education, farm size (land for dairy farming and cow), milking systems, insemination, breeding and services. Two regression models were estimated. Model V includes farm size (milk, cow and land), feed and labour costs, and Model VI introduces education level, milking systems, insemination, breed and services variables to capture potential effects on TE.

\section{Model V:}

$T E$

$=f(C O W, L A N D, M I L K, F E E D, L A B O U R)$

where:

TE is technical efficiency level, as measured in this study;

COW is the number of cows;

LAND is the number of hectares for dairy farming;

MILK is the number of milk production;

FEED are the feed costs;

LABOUR are the labour costs.

Model VI: 
$T E$
$=f\left(\begin{array}{c}C O W, L A N D, M I L K, F E E D, L A B O U R \\ \text { BREU } 2, E D U 3, \text { OBREEDS, SER }\end{array}\right.$

where:

EDU1 is a dummy variable equal to 1 if the farmer has less than high school education and 0 otherwise (excluded category);

EDU2 is a dummy variable equal to 1 if the farmer finished high school and 0 otherwise;

EDU3 is a dummy variable equal to 1 if the farmer has higher education;

MSYS is a dummy variable equal to 1 if the dairy farm uses pipeline and 0 otherwise (flat barn and pit parlor);

INS is a dummy variable equal to 1 if the dairy farm uses insemination and 0 otherwise;

BREED is the number of cows of the Dutch breed;

OBREED is the number of cows of the others breed;

SER is a dummy variable equal to 1 if the dairy farm uses technical assistance services and 0 otherwise.

COW, LAND, MILK, FEED, LABOUR are defined as in equation 5.

Models V and VI are estimated using the Tobit and OLS procedures, considering the Marginal Effects. STATA version 11 software was used to find out the determinants of TE. The next subsection presents a synthesis of the thesis organization and methods.

\section{3}

\section{Thesis organization and methods}

Figure 6 presents a synthesis of the thesis organization and methods. 


\section{OBJECTIVE OF THESIS}

This thesis develops a research synthesis on TE in dairy farms, both qualitative (meta-synthesis) and quantitative (meta-regression analysis) and offers an empirical study aiming at measuring and understanding the factors affecting the TE in dairy farms of selected municipalities in the South of Brazil

\section{RESEARCH SYNTHESIS}

\section{META-SYNTHESIS}

The goal of the meta-synthesis was to integrate the findings of existing studies about TE in dairy farms offering a research framework as a structuring tool to assemble TE descriptors from the extant literature and synthesizing results as researchable and verifiable propositions

$\downarrow$<smiles>C1C[Al]1</smiles>

Research framework: context, inputs, outputs and metrics of TE

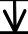

Propositions were derived from the prevailing views in the majority of the papers
META-REGRESSION ANALYSIS

The goal of the metaregression analysis is applied to analysing the effects of different methodologies and study-specific characteristics on Mean TE (MTE)<smiles>[3H]C#CC#CC</smiles>

Hypotheses were presented and the results compared with other studies

Others studies: Rivas, 2003; Moreira López, 2006; BravoUreta et al., 2007

Figure 6: Synthesis of the Thesis organization and methods

The goal of this thesis is to present a research synthesis on TE in dairy farms and offer an empirical study aiming at measuring and understanding the factors affecting the TE in dairy farms of selected municipalities in the South of Brazil. The research synthesis is presented in two parts: meta-synthesis and metaregression analysis. The goal of the meta-synthesis is to integrate the findings of existing 103 studies about TE in dairy farms through a systematic literature review, offering a research synthesis framework (context and determinants, inputs, outputs and measurement techniques) and synthesizing results as researchable and verifiable propositions. The meta-regression analysis verifies from the 103 published papers (531 distributions of TE in dairy farms) the effects that different methodologies and study-specific characteristics have on MTE. Based on the extant literature and the previous systematic literature review, 
hypotheses are presented and the results compared with other studies. Finally, the empirical study is developed in two-stages. First it obtains efficiency level through DEA and then tests hypothesis that emerged from the research synthesis. 


\section{Research Synthesis}

This chapter presents and analyses results from the research synthesis regrouped in three subsections: study identification, meta-synthesis analysis and meta-regression analysis. The last two subsections include results' discussions subsections closing each of them.

\section{1}

\section{Study identification}

There is an upward time trend in published papers reflecting the growing and sustained interest in the subject. The first publications available in electronic databases trace back to the 1980s, but there are relatively few papers published or indexed in databases during the last century. Figure 7 shows the numbers of publications by year, in five-year groups. The series reach a pick in 2010-14, with 40 papers published until December 2014.

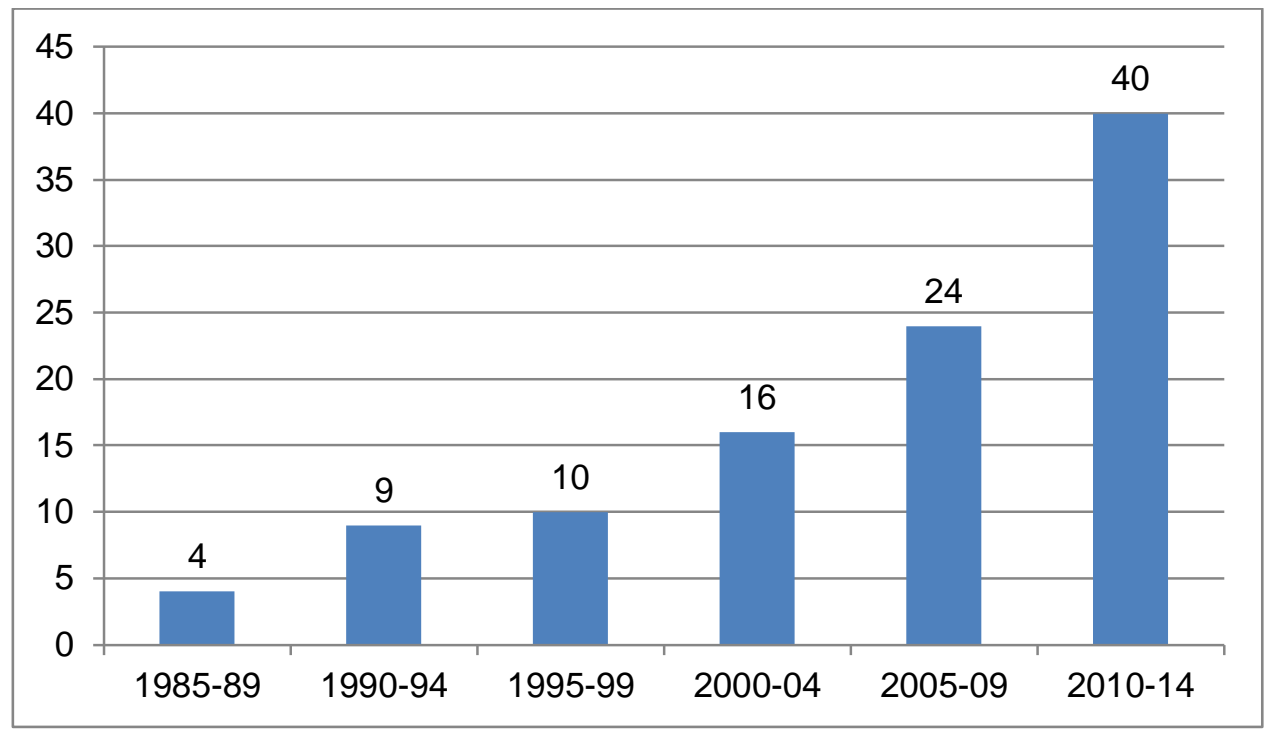

Figure 7: Number of publications on TE in dairy farms in five-year groups $(\mathrm{N}=103)$ 
A list of all the papers included in this review, by sources of publication authors and year, is presented in Table 2.

Table 2: Studies identification of TE in dairy farms

\begin{tabular}{|c|c|}
\hline Sources & Authors \\
\hline Acta Oeconomica et Informatica XVI & Michaličková, Krupová \& Krupa (2013) \\
\hline Agricultural and Resource Economics Review & Tauer (1993), Jiang \& Sharp (2014) \\
\hline Agricultural Economics & $\begin{array}{l}\text { Pierani \& Rizzi (2003), Alvarez \& Arias (2004), } \\
\text { Latruffe, Balcombe, Davidova \& Zawalinska } \\
\text { (2005), Nehring, Gillespie, Sandretto \& Hallahan } \\
\text { (2009) }\end{array}$ \\
\hline $\begin{array}{l}\text { Agricultural Economics Research, Policy and } \\
\text { Practice in Southern Africa }\end{array}$ & Gelan \& Muriithi (2012) \\
\hline Agricultural Systems & Fraser \& Cordina (1999), Hansson (2007) \\
\hline Agriculture \& Applied Economics Association's & $\begin{array}{l}\text { Chidmi, Solís, Funtanilla \& Cabrera (2010), } \\
\text { Dong, Hennessy \& Jensen (2013), Minegishi } \\
\text { (2013), Odening, Wagner, Narayana \& Huette } \\
\text { (2013), Pieralli, Hüttel \& Odening (2014) }\end{array}$ \\
\hline Agrociência & $\begin{array}{l}\text { Angón, García, Perea, Acero, Toro-Mújica, } \\
\text { Pacheco \& González (2013) }\end{array}$ \\
\hline American Agricultural Economics Association & $\begin{array}{l}\text { Wang (2001), Hadley, Shankar, Thirtle \& Coelli } \\
\text { (2001) }\end{array}$ \\
\hline American Journal of Agricultural Economics & $\begin{array}{l}\text { Bravo-Ureta \& Rieger (1991), Dawson, Lingard \& } \\
\text { Woodford (1991), Kumbhakar \& Heshmati } \\
\text { (1995), Álvarez \& Gonzalez (1999), Reinhard, } \\
\text { Lovell \& Thijssen (1999), Brümmer, Glauben \& } \\
\text { Thijssen (2002), Mayen, Balagtas \& Alexander } \\
\text { (2010) }\end{array}$ \\
\hline $\begin{array}{l}\text { Annual Conference of the Agricultural } \\
\text { Economics Society }\end{array}$ & Sauer \& Latacz-Lohmann (2013) \\
\hline Applied Economics & $\begin{array}{l}\text { Dawson \& White (1990), Heshmati (1998), } \\
\text { Haghiri, Nolan \& Tran (2004), Latruffe, } \\
\text { Balcombe, Davidova \& Zawalinska (2004); } \\
\text { Iráizoz, Bardaji \& Rapun (2005), Balcombe, } \\
\text { Fraser \& Kim (2006) }\end{array}$ \\
\hline Applied Studies in Agribusiness and Commerce & Kovacs \& Emvalomatis (2011) \\
\hline Archivos de medicina veterinaria & $\begin{array}{l}\text { Moreira Lopez, Bravo-Ureta, Carrillo \& Vásquez } \\
(2006 \text { b) }\end{array}$ \\
\hline Australian Accounting Review & Rouse, Harrison \& Chen (2010) \\
\hline $\begin{array}{l}\text { Australian Journal of Agricultural na Resource } \\
\text { Economics }\end{array}$ & $\begin{array}{l}\text { Jaforullah \& Whiteman (1999), Kompas \& Che } \\
\text { (2006), Mugera (2013) }\end{array}$ \\
\hline Canadian Journal of Agricultural Economics & $\begin{array}{l}\text { Thomas \& Tauer (1994), Mbaga, Romain, Larue } \\
\text { \& Lebel (2003) }\end{array}$ \\
\hline $\begin{array}{l}\text { Center for Research on the economics of the } \\
\text { Environment, Agri-food, Transports and Energy }\end{array}$ & Singbo \& Larue (2014) \\
\hline Chilean journal of agricultural research & $\begin{array}{l}\text { Bravo-Ureta, Moreira, Arzubi, Schilder, Álvarez \& } \\
\text { Molina (2008) }\end{array}$ \\
\hline China Agricultural Economic Review & $\begin{array}{l}\text { Xiaohua (2012), Uddin, Brümmer \& Peters } \\
\text { (2014) }\end{array}$ \\
\hline $\begin{array}{l}\text { Conference of the Agricultural Economics } \\
\text { Society }\end{array}$ & Lopes (2008) \\
\hline
\end{tabular}




\begin{tabular}{|c|c|}
\hline Sources & Authors \\
\hline $\begin{array}{l}\text { Congress 'Agri-Food and Rural Innovations for } \\
\text { Healthier Societies' }\end{array}$ & $\begin{array}{l}\text { Ang \& Oude Lansink (2014), Luik, Viira \& Värnik } \\
\text { (2014), Mamardashvili \& Jan (2014), Skevas, } \\
\text { Zhu, Shestalova \& Emvalomatis (2014) }\end{array}$ \\
\hline Ecnomics Letters & Tran \& Tsionas (2013) \\
\hline Ecological Economics & Areal, Tiffin \& Balcombe (2012) \\
\hline Ecological Indicators & Shortall \& Barnes (2013) \\
\hline Economía Agraria & $\begin{array}{l}\text { Moreira Lopez, Bravo-Ureta, Arzubi \& Schilder } \\
\text { (2006a) }\end{array}$ \\
\hline Economia Aplicada & Gonçalves, Vieira, Lima \& Gomes (2008) \\
\hline Economic Modelling & Yélou, Larue \& Tran (2010) \\
\hline Economic Systems & Latruffe, Fogarasi \& Desjeux (2012) \\
\hline $\begin{array}{l}\text { European Association of Agricultural } \\
\text { Economists }\end{array}$ & $\begin{array}{l}\text { Fogarasi \& Latruffe (2007a); Fogarasi \& Latruffe } \\
\text { (2007b) }\end{array}$ \\
\hline European Journal of Operational Research & Reinhard, Lovell \& Thijssen (2000) \\
\hline European Review of Agricultural Economics & Hallam \& Machado (1996), Maietta (2000) \\
\hline Industrial Management \& Data Systems & Bojnec \& Latruffe (2008) \\
\hline $\begin{array}{l}\text { International Congress of the European } \\
\text { Association of Agricultural Economists }\end{array}$ & Johansson (2005) \\
\hline Journal of Agricultural Economics & $\begin{array}{l}\text { Bravo-Ureta \& Rieger (1990); Tauer (1998), } \\
\text { Brümmer \& Loy (2000), Hadley (2006), Barnes } \\
\text { (2008) }\end{array}$ \\
\hline Journal of Business \& Economic Statistics & Kumbhakar, Ghosh \& McGuckin (1991) \\
\hline Journal of Comparative Economics & Piesse, Thirtle \& Turk (1996) \\
\hline Journal of Dairy Science & $\begin{array}{l}\text { D'Haese, Speelman, Alary, Tillard \& D'Haese } \\
\text { (2009), Cabrera, Solís \& Del Corral (2010), } \\
\text { Chang \& Mishra (2011), Del Corral, Perez \& } \\
\text { Roibas (2011), Barnes, Rutherford, Langford \& } \\
\text { Haskell (2011); Ma, Oxley, Rae, Fan, Huang \& } \\
\text { Rozelle (2012), Steeneveld, Tauer, Hogeveen \& } \\
\text { Oude Lansink (2012), Kellermann \& Salhofer } \\
\text { (2014), Van der Voort, Van Meensel, Lauwers, } \\
\text { Vercruysse, Van Huylenbroeck \& Charlier (2014) }\end{array}$ \\
\hline Journal of Econometrics & Battese \& Coelli (1988) \\
\hline Journal of Productivity Analysis & $\begin{array}{l}\text { Heshmati \& Kumbhakar (1994), Ahmad \& Bravo- } \\
\text { Ureta (1996), Cuesta (2000), Karagiannis, } \\
\text { Midmore \& Tzouvelekas (2002), Asmild, } \\
\text { Hougaard, Kronborg \& Kvist (2003), Orea, } \\
\text { Roibás \& Wall (2004), Kumbhakar, Tsionas \& } \\
\text { Sipiläinen (2009), Moreira Lopez \& Bravo-Ureta } \\
\text { (2010) }\end{array}$ \\
\hline Livestock Science & Hansson \& Öhlmér (2008) \\
\hline NJAS - Wageningen Journal of Life Sciences & Keizer \& Emvalomatis (2014) \\
\hline $\begin{array}{l}\text { Northeastern Journal of Agricultural and } \\
\text { Resource Economics }\end{array}$ & Tauer \& Belbase (1987) \\
\hline Organizações Rurais \& Agroindustriais & Santos, Vieira \& Baptista (2005) \\
\hline Oxford Bulletin of Economics and Statistics & Tsionas (2007) \\
\hline Quarterly Journal of International Agriculture & Ohlan (2013) \\
\hline nia & $\begin{array}{l}\text { Nascimento, Lima, Braga, Nascimento \& Gomes } \\
\text { (2012), Sousa, Campos \& Gomes (2012) }\end{array}$ \\
\hline Revista de Economia e Agronegócio & Santos, Vieira \& Baptista (2004) \\
\hline Revista de Economia e Sociologia Rural & Magalhães \& Campos (2006) \\
\hline Springer Plus & Bardhan \& Sharma (2013) \\
\hline Studies in Agricultural Economics & Fogarasi \& Latruffe (2009) \\
\hline
\end{tabular}




\begin{tabular}{l|l}
\hline \multicolumn{1}{c|}{ Sources } & \multicolumn{1}{c}{ Authors } \\
\hline \hline Technological Forecasting and Social Change & Ghosh, McGuckin \& Kumbhakar (1994) \\
\hline The review of Economics and Statistics & Kumbhakar, Biswas \& Von Bailey (1989) \\
\hline Western Journal of Agricultural Economics & Bailey, Biswas, Kumbhakar \& Schulthies (1989) \\
\hline \hline
\end{tabular}

The 103 papers retrieved for this research were published in 54 different sources, with almost half of them (45\%) concentrated in seven sources, in the following decreasing order: Journal of Dairy Science, Journal of Productivity Analysis, American Journal of Agriculture Economics, Applied Economics, Agriculture \& Applied Economics Association, Journal of Agriculture Economics and Agricultural Economics. The distribution of the number of publications by author also show some concentration: Bravo-Ureta, Latruffe and Kumbhakar coauthored 7 out of the 103 papers; Balcombe, Fogarasi, Moreira López and Tauer were involved in 4 papers and Barnes, Brümmer, Emvalomatis, Heshmati, Larue, Thijssen, Tran, Tsionas and Vieira co-authored 3 papers each.

\section{2 \\ Meta-synthesis}

To assist in summarizing the empirical results, a conceptual research synthesis framework is proposed as a structuring tool to assemble TE descriptors from the extant literature. The framework is depicted in Figure 8 and displays contextual information belonging to the external environment of dairy farms, such as countries/geographical location, socio-economic characteristics (e.g., age, education), infrastructure, human resources, technology, public policies, and development programs. The contextual conditions would influence inputs and outputs of TE. Inputs comprise variables included as entries in TE models. The most commonly encountered inputs are size (measured in different ways, e.g., number of cows, land), capital, production techniques (e.g., feeding, veterinary controls) (Bailey et al., 1989; Hallam \& Machado, 1996). Outputs are usually the amounts of milk or other products or yet the monetary value of income generated by milk or by other products (Barnes et al., 2011; Mugera, 2011; Latruffe et al., 2012; Pieralli et al., 2014). 


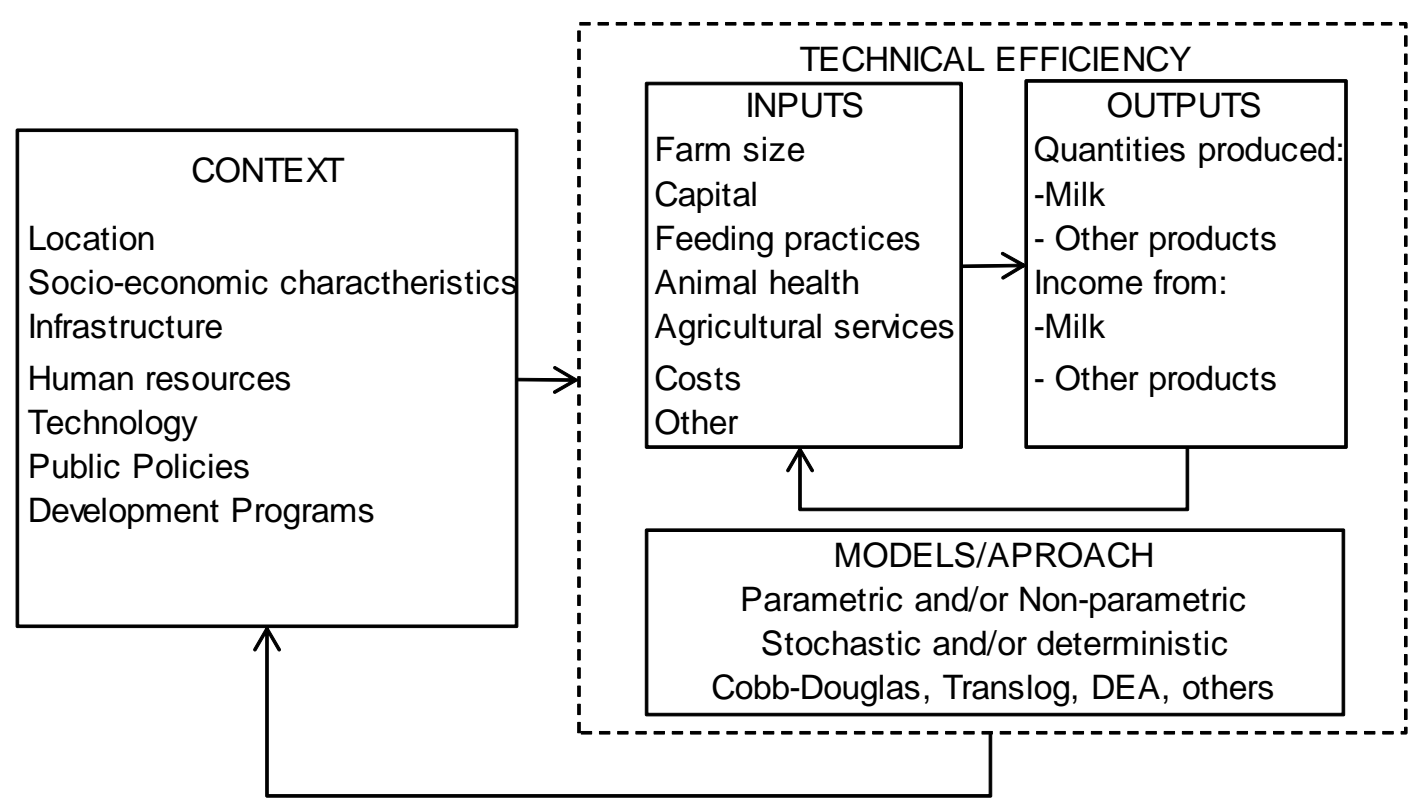

Figure 8: Research synthesis framework

The units of analysis for this review are dairy farms, although some studies calculate TE for other types of agricultural production as well. Therefore, only dairy farm's TE is included here. All variables of each unit of analysis can be used both to measure and to explain TE. Therefore, besides figuring as input and output variables, the same variables might be used as a determinant explaining the variations and differentials of TE (Bailey et al., 1989; Bravo-Ureta \& Rieger, 1991; Ahmad \& Bravo-Ureta, 1996; Hallam \& Machado, 1996; Mbaga et al., 2003; Johansson, 2005).

An additional step taken to measure efficiency is the choice of measurement techniques (Farrell, 1957; Charnes et al., 1978). There are two basic approaches used for the measurement of TE: parametric and non-parametric models. Parametric frontiers must use predetermined functional forms (e.g., CobbDouglas, Translog, Transcendental) and they rely on pre-specified types of error distributions (e.g., half-normal, truncated normal, exponential, gamma), while non-parametric models do not have limitations of estimators (Coelli, 1995; Haghiri et al., 2004). In addition, estimation procedures can be deterministic or stochastic. Deterministic models assume that any deviation from the frontier is due to technical inefficiency (TI), while stochastic models are compound by an error term accounting for TI and random noise (Greene, 1993; Coelli, 1995). 
The following subsections present key findings from the literature review, organized in accordance with the research framework of Figure 8, as follows: (i) context and determinants of TE, (ii) inputs, outputs and measurement techniques. Finally, the last subsection offers the discussions about the meta-synthesis.

\subsection{1}

\section{Context and determinants of TE}

Several authors have discussed the determinants of TE because understanding these factors can improve efficiency and performance of dairy farms.

Table 3 presents the 51 papers that analyse the determinants of TE, organized by explanatory variables or determinants. These studies adopted a twostep approach to analyse TE: (i) use of input and output variables to derive the TE rate, and (ii) inclusion of inputs in multiple regression equations to estimate the determinants of TE. The main variables investigated in the studies are in the first column of Tabela 3. Studies showing a statistically significant effect of the variable on TE are in Column 2, and Column 3 reports the studies that did not find a statistically significant effect of the same variable on the level of TE.

It is readily apparent in Table 3 that different authors find different explanatory power for the same variable, which statistically affects TE in some studies but not in others. This makes the summary interpretation of the models at least difficult. In the remaining of this thesis, we will synthesize the state of the art in dairy farms with research propositions derived from the prevailing views in the majority of the papers.

Despite the lack of general agreement, one might hypothesize that dairy farms with high levels of TE tend to be in a favourable context. The geographical locations of the retrieved studies include different continents, as showed Figure 9. The largest number of studies can be observed for Western Europe and Oceania (54), followed by North America (United States and Canada, 23), Latin America (12), Eastern Europe (9), Asia (5), and Africa (1). 


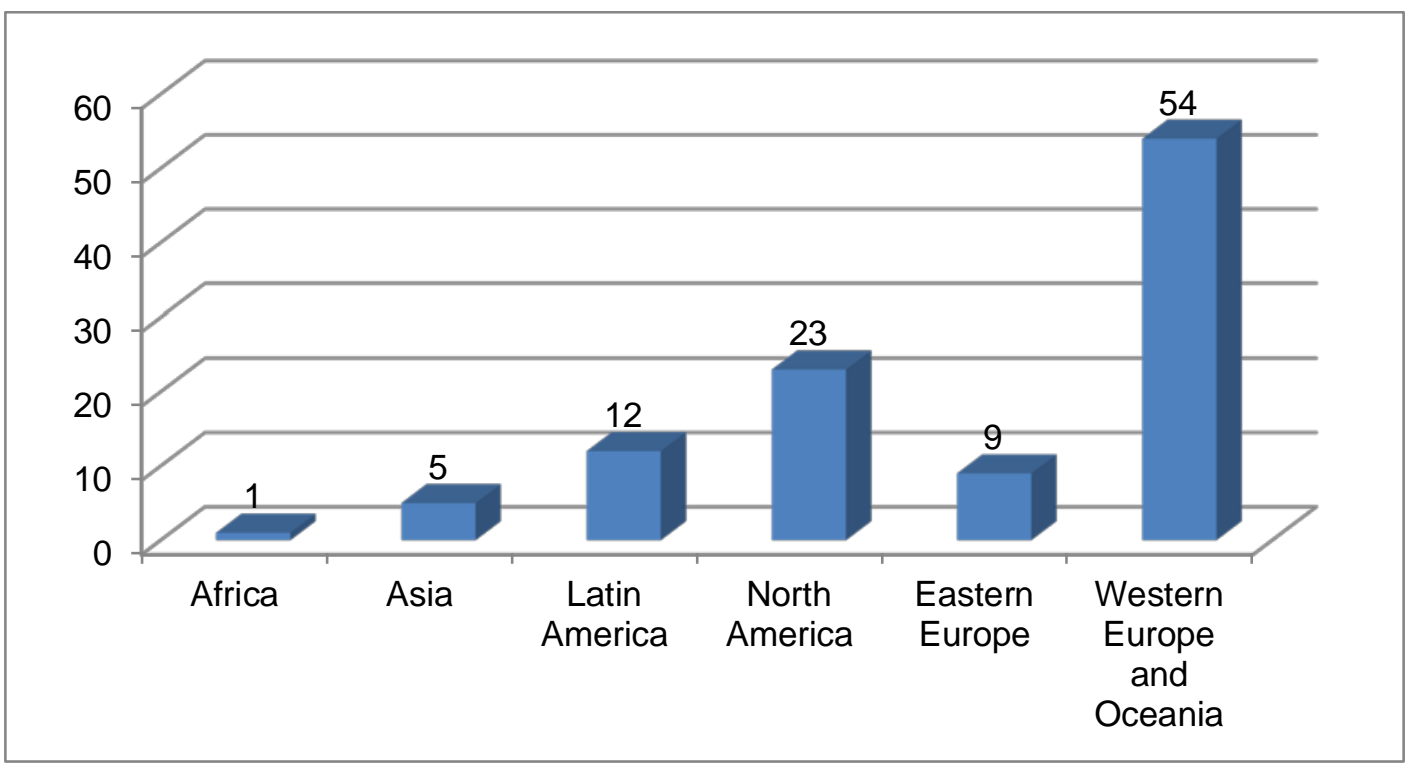

Figure 9: Geographical locations

Other contextual variables were the geographical location of farms operating in environment with different climate (Rouse et al., 2010) or altitude conditions (Sauer \& Latacz-Lohmann, 2013), with different soil quality (Latruffe et al., 2004); and having different quality of human capital in terms of educational training (Sauer \& Latacz-Lohmann, 2013). In addition, using TE results it was found that dairy extension agents (e.g., public policies of extension services) can detect the problems preventing the farms from achieving full efficiency. By studing these management practices, efficiency and performance could be improved through farmers' training and direct incentives (Jaforullah \& Whiteman, 1999; Bravo-Ureta \& Rieger, 1991). We therefore enunciate two propositions:

P1 - Dairy farms situated in favourable geographical climate and altitude, with good soil quality and qualified human resources have high TE.

P2 - Dairy farms located in contexts with public policies favouring milking practices have high TE. 
Table 3: Determinants of TE

\begin{tabular}{|c|c|c|}
\hline \multirow{2}{*}{ Variables } & \multicolumn{2}{|l|}{ Results } \\
\hline & Significant & Non-significant \\
\hline $\begin{array}{l}\text { Location and } \\
\text { Environment }\end{array}$ & $\begin{array}{l}\text { Tauer \& Belbase (1987), Hallam \& } \\
\text { Machado (1996), Haghiri et al. (2004), } \\
\text { Latruffe et al. (2004, 2005), Hansson } \\
\text { (2007), Rouse et al. (2010), Del Corral et } \\
\text { al. (2011), Areal et al. (2012), Sauer \& } \\
\text { Latacz-Lohmann (2013), Dong et al. } \\
\text { (2013), Minegishi (2013) }\end{array}$ & \begin{tabular}{|l} 
Tauer \& Belbase (1987), \\
Kumbhakar et al. (1991), \\
Heshmati (1998), Alvarez \& \\
González (1999), Hansson (2007), \\
Rouse et al. (2010), Shortall \& \\
Barnes (2013), Dong et al. (2013), \\
Minegishi (2013)
\end{tabular} \\
\hline Age & $\begin{array}{l}\text { Alvarez \& González (1999), Brümmer \& } \\
\text { Loy (2000), Hadley (2001, 2006), Latruffe } \\
\text { et al. (2005), Gonçalves et al. (2008), } \\
\text { Kumbhakar et al. (2009), Bardhan \& } \\
\text { Sharma (2013), Sauer \& Latacz-Lohmann } \\
\text { (2013), Dong et al. (2013), Luik et al. } \\
\text { (2014) }\end{array}$ & $\begin{array}{l}\text { Tauer \& Belbase (1987), Bravo- } \\
\text { Ureta \& Rieger (1991), Tauer } \\
\text { (1993), Latruffe et al. (2004, } \\
\text { 2005), Iráizoz et al. (2005), } \\
\text { Gonçalves et al. (2008), } \\
\text { Kumbhakar et al. (2009), Gelan \& } \\
\text { Muriithi (2012), Chang \& Mishra } \\
\text { (2011), Areal et al. (2012), } \\
\text { Bardhan \& Sharma (2013), Luik et } \\
\text { al. (2014) }\end{array}$ \\
\hline Education & $\begin{array}{l}\text { Kumbhakar et al. (1991), Gonçalves et al. } \\
\text { (2008), Chang \& Mishra (2011), Ma et al. } \\
\text { (2012), Nascimento et al. (2012), Sauer \& } \\
\text { Latacz-Lohmann (2013), Dong et al. (2013) }\end{array}$ & $\begin{array}{l}\text { Tauer \& Belbase (1987), Bravo- } \\
\text { Ureta \& Rieger (1991), Tauer } \\
\text { (1993), Latruffe et al. (2004), } \\
\text { Gonçalves et al. (2008), D'Haese } \\
\text { et al. (2009), Gelan \& Muriithi } \\
\text { (2012), Nascimento et al. (2012), } \\
\text { Bardhan \& Sharma (2013), Dong } \\
\text { et al. (2013), Shortall \& Barnes } \\
\text { (2013) }\end{array}$ \\
\hline Land & $\begin{array}{l}\text { Alvarez \& González (1999), Latruffe et al. } \\
\text { (2004, 2005), Iráizoz et al. (2005), Kompas } \\
\text { \& Che (2006), Hadley (2001, 2006), } \\
\text { Barnes (2008), Rouse et al. (2010), Del } \\
\text { Corral et al. (2011), Areal et al. (2012), } \\
\text { Nascimento et al. (2012), Dong et al. } \\
\text { (2013), Ang \& Oude Lansink (2014), Luik } \\
\text { et al. (2014) }\end{array}$ & $\begin{array}{l}\text { Tauer \& Belbase (1987), } \\
\text { Heshmati (1998), Alvarez \& } \\
\text { González (1999), Latruffe et al. } \\
\text { (2004, 2005), Iráizoz et al. (2005), } \\
\text { Maietta (2000), Hadley (2006), } \\
\text { Kompas \& Chu (2006), Hallam \& } \\
\text { Machado (1996), Hansson (2007), } \\
\text { Gelan \& Muriithi (2010), Rouse et } \\
\text { al. (2010), Nascimento et al. } \\
\text { (2012), Bardhan \& Sharma } \\
\text { (2013), Skevas et al. (2014) } \\
\end{array}$ \\
\hline Cows & $\begin{array}{l}\text { Tauer \& Belbase (1987), Bravo-Ureta \& } \\
\text { Rieger (1990, 1991), Kumbhakar et al. } \\
\text { (1989, 1991), Tauer (1993), Ahmad \& } \\
\text { Bravo-Ureta (1996), Hallam \& Machado } \\
\text { (1996), Heshmati (1998), Alvarez \& } \\
\text { González (1999), Brümmer \& Loy (2000), } \\
\text { Alvarez \& Arias (2004), Kompas \& Chu } \\
\text { (2006), Hadley (2001, 2006), Gelan \& } \\
\text { Muriithi (2012), Ma et al. (2012), } \\
\text { Nascimento et al. (2012), Bardhan \& } \\
\text { Sharma (2013), Shortall \& Barnes (2013), } \\
\text { Dong et al. (2013), Jiang \& Sharp (2014), } \\
\text { Luik et al. (2014), Van der Voort et al. } \\
\text { (2014) }\end{array}$ & $\begin{array}{l}\text { Alvarez \& González (1999), } \\
\text { Bardhan \& Sharma (2013), Areal } \\
\text { et al. (2012), Luik et al. (2014), } \\
\text { Van der Voort et al. (2014) }\end{array}$ \\
\hline Farm s & $\begin{array}{l}\text { Alvarez \& González (1999), Johansson } \\
\text { (2005), Iráizoz et al. (2005), Gonçalves et } \\
\text { al. (2008), Shortall \& Barnes (2013), Luik } \\
\text { et al. (2014), Skevas et al. (2014) }\end{array}$ & $\begin{array}{l}\text { Alvarez \& González (1999), } \\
\text { Haghiri et al. (2004), Iráizoz et al. } \\
\text { (2005), Gonçalves et al. (2008) }\end{array}$ \\
\hline
\end{tabular}




\begin{tabular}{|c|c|c|}
\hline \multirow{2}{*}{ Variables } & \multicolumn{2}{|l|}{ Results } \\
\hline & Significant & Non-significant \\
\hline $\begin{array}{l}\text { Feeding } \\
\text { practices }\end{array}$ & $\begin{array}{l}\text { Ahmad \& Bravo-Ureta (1996), Hallam \& } \\
\text { Machado (1996), Alvarez \& González } \\
\text { (1999), Kompas \& Chu (2006), Cabrera et } \\
\text { al (2010), Chidmi et al. (2010), Gelan \& } \\
\text { Muriithi (2012), Del Corral et al. (2011), } \\
\text { Chang \& Mishra (2011), Ma et al. (2012), } \\
\text { Michaličková et al. (2013), Dong et al. } \\
\text { (2013), Luik et al. (2014), Van der Voort et } \\
\text { al. (2014) }\end{array}$ & $\begin{array}{l}\text { Alvarez \& González (1999), } \\
\text { Hansson (2007), Hansson \& } \\
\text { Öhlmér (2008), Cabrera et al } \\
\text { (2010), Del Corral et al. (2011), } \\
\text { Sauer \& Latacz-Lohmann (2013), } \\
\text { Van der Voort et al. (2014) }\end{array}$ \\
\hline $\begin{array}{l}\text { Animal } \\
\text { health }\end{array}$ & $\begin{array}{l}\text { Alvarez \& González (1999), Hansson \& } \\
\text { Öhlmér (2008), Gelan \& Muriithi (2012), } \\
\text { Chidmi et al. (2010), Barnes et al. (2011), } \\
\text { Luik et al. (2014), Van der Voort et al. } \\
\text { (2014) }\end{array}$ & $\begin{array}{l}\text { Hansson \& Öhlmér (2008), Barnes } \\
\text { et al. (2011), Van der Voort et al. } \\
\text { (2014) }\end{array}$ \\
\hline Services & $\begin{array}{l}\text { Bravo-Ureta \& Rieger (1991), Gonçalves et } \\
\text { al. (2008), Chang \& Mishra (2011), Dong et } \\
\text { al. (2013), Uddin et al. (2014) }\end{array}$ & $\begin{array}{l}\text { Gonçalves et al. (2008), } \\
\text { Nascimento et al. (2012), } \\
\text { Michaličková et al. (2013), Uddin } \\
\text { et al. (2014) }\end{array}$ \\
\hline $\begin{array}{l}\text { Infrastructure } \\
\text { and } \\
\text { Technology }\end{array}$ & $\begin{array}{l}\text { Hallam \& Machado (1996), Latruffe et al. } \\
\text { (2004, 2005), Kompas \& Chu (2006), } \\
\text { Hansson (2007), Gonçalves et al. (2008), } \\
\text { Kumbhakar et al. (2009), Cabrera et al } \\
\text { (2010), Chidmi et al. (2010), Chang \& } \\
\text { Mishra (2011), Del Corral et al. (2011), Ma } \\
\text { et al. (2012), Minegishi (2013), Jiang \& } \\
\text { Sharp (2014) }\end{array}$ & $\begin{array}{l}\text { Tauer \& Belbase (1987), Tauer } \\
\text { (1993), Iráizoz et al. (2005), } \\
\text { Hansson (2007), Cabrera et al } \\
\text { (2010), Chidmi et al. (2010), } \\
\text { Gelan \& Muriithi (2012), Del Corral } \\
\text { et al. (2011), Ma et al. (2012), } \\
\text { Jiang \& Sharp (2014) }\end{array}$ \\
\hline Finance & $\begin{array}{l}\text { Hallam \& Machado (1996), Hadley et al. } \\
\text { (2001, 2006), Latruffe et al. (2004, 2005), } \\
\text { Iráizoz et al. (2005), Barnes (2008), } \\
\text { Gonçalves et al. (2008), Kumbhakar et al. } \\
\text { (2009), Chidmi et al. (2010), Chang \& } \\
\text { Mishra (2011), Areal et al. (2012), } \\
\text { Nascimento et al. (2012), Sauer \& Latacz- } \\
\text { Lohmann (2013), Bardhan \& Sharma } \\
\text { (2013), Ang \& Oude Lansink (2014), Luik } \\
\text { et al. (2014), Skevas et al. (2014), Uddin et } \\
\text { al. (2014) }\end{array}$ & $\begin{array}{l}\text { Tauer \& Belbase (1987), Alvarez } \\
\text { \& González (1999), Latruffe et al. } \\
\text { (2005), Hadley (2006), Gonçalves } \\
\text { et al. (2008), Rouse et al. (2010), } \\
\text { Gelan \& Muriithi (2012), Areal et } \\
\text { al. (2012), Bardhan \& Sharma } \\
\text { (2013), Dong et al. (2013), } \\
\text { Minegishi (2013), Luik et al. } \\
\text { (2014), Skevas et al. (2014), } \\
\text { Uddin et al. (2014) }\end{array}$ \\
\hline $\begin{array}{l}\text { Programs } \\
\text { and } \\
\text { marketing }\end{array}$ & $\begin{array}{l}\text { Tauer \& Belbase (1987), Brümmer \& Loy } \\
\text { (2000), Latruffe et al. (2004), Iráizoz et al. } \\
\text { (2005), Gonçalves et al. (2008), Gelan \& } \\
\text { Muriithi (2012), Chidmi et al. (2010), Chang } \\
\text { \& Mishra (2011) }\end{array}$ & $\begin{array}{l}\text { Tauer \& Belbase (1987), Brümmer } \\
\text { \& Loy (2000), Gonçalves et al. } \\
\text { (2008), Gelan \& Muriithi (2012) }\end{array}$ \\
\hline $\begin{array}{l}\text { Information } \\
\text { management }\end{array}$ & Tauer \& Belbase (1987) & $\begin{array}{l}\text { Tauer \& Belbase (1987), Tauer } \\
\text { (1993), Chang \& Mishra (2011), } \\
\text { Bardhan \& Sharma (2013) } \\
\end{array}$ \\
\hline $\begin{array}{l}\text { Investment } \\
\text { and costs }\end{array}$ & $\begin{array}{l}\text { Bravo-Ureta \& Rieger (1990), Ahmad \& } \\
\text { Bravo-Ureta (1996), Iráizoz et al. (2005), } \\
\text { Latruffe et al. (2005), Gonçalves et al. } \\
\text { (2008), Chidmi et al. (2010), Rouse et al. } \\
\text { (2010), Cabrera et al (2010), Del Corral et } \\
\text { al. (2011), Nascimento et al. (2012), Sauer } \\
\text { \& Latacz-Lohmann (2013), Jiang \& Sharp } \\
\text { (2014), Luik et al. (2014), Skevas et al. } \\
\text { (2014), Uddin et al. (2014), Van der Voort } \\
\text { et al. (2014) }\end{array}$ & $\begin{array}{l}\text { Hallam \& Machado (1996), } \\
\text { Latruffe et al. (2004), Rouse et al. } \\
\text { (2010), Nascimento et al. (2012), } \\
\text { Michaličková et al. (2013), Sauer } \\
\text { \& Latacz-Lohmann (2013), Luik et } \\
\text { al. (2014), Uddin et al. (2014), Van } \\
\text { der Voort et al. (2014) }\end{array}$ \\
\hline
\end{tabular}


Another determinant was related to farm size (included as inputs in Figure 8), measured by the number of cows (Kumbhakar et al., 1989; Bravo-Ureta \& Rieger, 1990; Bravo-Ureta \& Rieger, 1991; Alvarez \& Arias, 2004). Care with animal health (Hansson \& Öhlmér, 2008; Gelan \& Muriithi, 2010), feeding practices, such as fodder and feed (Chang \& Mishra, 2011; Ma et al., 2012), the use of automatic milking systems and frequency of milking (Hansson, 2007; Chang \& Mishra, 2011; Chidmi et al., 2010) were also discriminant. Dairy farms in better financial health (e.g., debt per cow, financial pressure) (Hadley, 2006; Barnes, 2008; Chidmi et al., 2010; Areal et al., 2012); with more investments per cow (Bravo-Ureta \& Rieger, 1990; Chidmi et al., 2010); and making larger use of agricultural services, such as extension, nutritionist and veterinary services (Chang \& Mishra, 2011; Dong et al., 2013) were also deemed to be better off in terms of TE. Generally, large size farms would more easily invest in human capital, animal health and agricultural services. This would indirectly explain why large farms are more technically efficient. We therefore put forward the two additional propositions:

P3 - Large dairy farms have higher TE than smaller farms.

P4 - Care with animal health, feeding practices, milking systems, direct investments and use of agricultural services mediate or moderate the effect of farm size on TE.

Other factors not shown in Table 3 that might also affect TE are statistical artefacts (number of variables included in the regression), measurement techniques and the quality of data collection. The level of TE increases when the number of variables included in the model increases (Thomas \& Tauer, 1994; Chavas et al., 2005; Bravo-Ureta et al., 2007), although results on model dimensionality are not always statistically significant (Moreira López, 2006).

Measurement techniques can also affect TE, but again there was no agreement among authors. Bravo-Ureta and Rieger (1990) and Balcombe et al. (2006) used several frontier functions to estimate TE in dairy farms and concluded that the ranking of TE levels appears to be independent of the method used. Ahmad and Bravo-Ureta (1996, p. 410) comments, "Technical efficiency measures do not appear to be affected by the choice of functional form". 
However, Mbaga et al. (2003, p. 121) quoted, "the differences in the mean levels of efficiency are statistically significant across functional forms and distributions, although the magnitude of the difference is minuscule”. Mbaga et al. (2003) also showed low correlation coefficients and rank-correlation coefficients between Data Envelopment Analysis (DEA) and parametric models.

Regarding data quality, Álvarez and González (1999) show that TE appeared to be positively related to farm's size before adjusting for raw input data; and the opposite after adjustment. They caution, "A wrong recommendation could be given if the information about input quality is not available" (Álvarez \& González, 1999, p. 901). These factors lead to another two propositions:

P5 - The levels of TE in dairy farms vary according to the measurement technique used.

P6 - The determinants of TE in dairy farms varies according to the number of variables included in the models and the primary data quality.

\subsection{2}

Inputs, outputs and measurement techniques

The study descriptors of inputs, outputs and measurement techniques are in Table 4. Most inputs to the process of measurement of TE are inventory and costs factors, with a larger concentration on aspects pertaining to labour (L), land (A), capital (K), feed (Fe) and cow (C). Veterinary, pasture and breeding prevail among inputs related to animal health. Artificial insemination, breeding, bovine somatotropin (bST), health, services, pasture and veterinary are examples of animal health (AH) or management practices (Hansson \& Öhlmér, 2008; Mayen et al., 2010; Chang \& Mishra, 2011; Dong et al., 2013). Some management practices explain the efficiency scores, such as improved breeds and bST. Therefore, the following three propositions are put forward:

P7 - The levels of TE in dairy farms vary according to the management practices adopted. 
P8 - It is possible to observe and derive "Best Practices" of management in dairy farms.

P9 - Best management practices lead to increased levels of TE in dairy farms. 
Table 4: Classification of inputs, outputs and metrics

\begin{tabular}{|c|c|c|c|c|c|c|c|c|c|c|c|c|c|c|c|c|c|c|c|}
\hline \multirow{4}{*}{$\begin{array}{c}\text { References } \\
\text { Authors } \\
\end{array}$} & \multirow{2}{*}{\multicolumn{8}{|c|}{ Inputs }} & \multirow{3}{*}{\multicolumn{3}{|c|}{ Outputs }} & \multicolumn{8}{|c|}{ Metrics } \\
\hline & & & & & & & & & & & & \multicolumn{3}{|c|}{ NP } & \multicolumn{5}{|c|}{$\mathbf{P}$} \\
\hline & \multicolumn{7}{|c|}{ Inventory and costs } & \multirow[t]{2}{*}{$\mathrm{AH}^{*}$} & & & & \multicolumn{2}{|l|}{$\mathrm{D}$} & \multirow{2}{*}{\begin{tabular}{|l|}
$\mathrm{S}$ \\
$\mathrm{O}$ \\
\end{tabular}} & \multicolumn{2}{|c|}{$\mathrm{D}$} & \multicolumn{3}{|c|}{$S$} \\
\hline & $\mathrm{K}$ & C & $\mathrm{Fe}$ & Fo & \begin{tabular}{|l|l|}
$\mathrm{L}$ & $\mathrm{A}$ \\
\end{tabular} & $\mathrm{OC}$ & $\mathrm{O}$ & & $\mathrm{M}$ & $\mathrm{Ou}$ & $\mathrm{OI}$ & DEA & $\mathrm{O}$ & & $\mathrm{CD}$ & TL & $\mathrm{CD}$ & $\mathrm{TL}$ & 0 \\
\hline Ahmad \& Bravo-Ureta (1996) & & $x$ & $x$ & & $x$ & $x$ & $\mathrm{Cr}, \mathrm{Ca}$ & & $x$ & & & & & & $x$ & $\mathrm{x}$ & $x$ & & \\
\hline Alvarez \& Arias (2004) & & $x$ & $\mathrm{x}$ & $x$ & \begin{tabular}{l|l|}
$x$ & $x$ \\
\end{tabular} & & & & $\mathrm{x}$ & & & & & & & $\mathrm{x}$ & & & \\
\hline Álvarez \& Gonzalez (1999) & & $x$ & $x$ & $x$ & \begin{tabular}{l|l|}
$x$ & $x$ \\
\end{tabular} & & & & $x$ & & & & & & & $\mathrm{x}$ & & & \\
\hline Ang \& Oude Lansink (2014) & & & & $x$ & $x \mid x$ & & $\begin{array}{l}\text { En, Se, Fer, } \\
\text { E, O }\end{array}$ & & $\mathrm{x}$ & Meat & & $x$ & & & & & & & \\
\hline Angón et al. (2013) & & $x$ & $x$ & & \begin{tabular}{|l|l|}
$x$ & $x$ \\
\end{tabular} & & & & $x$ & & & & & & & & $x$ & & \\
\hline Areal et al. (2012) & & $x$ & & & \begin{tabular}{|l|l|}
$x$ & $x$ \\
\end{tabular} & & E, Q, Li & & $x$ & Env, O & & & & & & & & $x$ & \\
\hline Asmild et al. (2003) & $x$ & & & & $x$ & $x$ & De, E & & & & $x$ & $x$ & & & & & & & \\
\hline Bailey et al. (1989) & $x$ & & $x$ & & \begin{tabular}{|l|l|}
$x$ & $x$ \\
\end{tabular} & & $E$ & $x$ & $x$ & & & & & & & & $x$ & & \\
\hline Balcombe et al. (2006) & & $x$ & $x$ & & & & Al, Fer & & $x$ & & & $x$ & & & & & & $x$ & \\
\hline Bardhan \& Sharma (2013) & & & $x$ & $x$ & $x$ & $x$ & $\mathrm{De}$ & $x$ & $x$ & & & & & & & & $x$ & & \\
\hline Barnes (2008) & $x$ & & $x$ & & \begin{tabular}{|l|l|}
$x$ & $x$ \\
\end{tabular} & & Se, Fer & & & & $x$ & & & & & & & $x$ & \\
\hline Barnes et al. (2011) & & $x$ & $x$ & $x$ & \begin{tabular}{|l|l|}
$x$ & $x$ \\
\end{tabular} & & $\mathrm{O}$ & & $x$ & & & $x$ & & & & & & & \\
\hline Battese \& Coelli (1988) & $x$ & & & $x$ & $x$ & & Se, Fer & & & & $x$ & & & & & & $x$ & & \\
\hline Bojnec \& Latruffe (2008) & $x$ & & & & \begin{tabular}{|l|l|}
$x$ & $x$ \\
\end{tabular} & & IC & & & $\mathrm{Cr}, \mathrm{Li}$ & $x$ & $x$ & & & & & $x$ & & \\
\hline Bravo-Ureta \& Rieger (1990) & & & $x$ & & $x$ & & $\mathrm{Ca}, \mathrm{E}$ & $x$ & $x$ & & & & & & $x$ & & $x$ & & \\
\hline Bravo-Ureta \& Rieger (1991) & & & $x$ & $x$ & $x$ & & & & $x$ & & & & & & & & $x$ & & \\
\hline Bravo-Ureta et al. (2008) & & $x$ & $x$ & & $x$ & & & $x$ & $x$ & & & & & & & & & $x$ & \\
\hline Brümmer \& Loy (2000) & $x$ & & & & \begin{tabular}{|l|l|}
$x$ & $x$ \\
\end{tabular} & & $\mathrm{Q}, \mathrm{IC}$ & & & & $x$ & & & & & & & $\mathrm{x}$ & \\
\hline Brümmer et al. (2002) & $x$ & & & & \begin{tabular}{|l|l|}
$x$ & $x$ \\
\end{tabular} & & IC & & $x$ & 0 & & & & & & & & $x$ & \\
\hline Cabrera et al. (2010) & $x$ & $x$ & $x$ & & $\mathrm{x}$ & & $\mathrm{Cr}, \mathrm{Li}$ & $x$ & $x$ & & & & & & & & $x$ & & \\
\hline $\begin{array}{l}\text { A - Land; AH - Animal Health; } \\
\text { Deterministic; De - Depreciatio } \\
\text { - Fertilizer; Fo - Fodder; IC - In } \\
\text { Milk; NP - Non-Parametric; O } \\
\text { Rent; S - Stochastic; Se - Seee }\end{array}$ & & & $\begin{array}{l}\text { Irrig } \\
\text { ata } \\
\text { Con } \\
\text { C - } \\
\text { Islog }\end{array}$ & & $\begin{array}{l}\text {; B - B } \\
\text { elopme } \\
\text { tion; II } \\
\text { er Cost } \\
\text { - Wate }\end{array}$ & $\begin{array}{l}\text { Butter } \\
\text { ent Ar } \\
\text { I - Int } \\
\text { sts; O } \\
\text { ter. }\end{array}$ & $\begin{array}{l}\text { Ifat; C - Con } \\
\text { nalysis; E - E } \\
\text { termediate In } \\
\text { I - Others In }\end{array}$ & $\begin{array}{l}-\mathrm{Ca} \\
\text { oment } \\
; \mathrm{K}-\mathrm{C}\end{array}$ & & $\begin{array}{l}\text { or anin } \\
\text { - Ener } \\
\text { ital; L - } \\
\text { Others }\end{array}$ & $\begin{array}{l}\text { l; CD } \\
\text { abou } \\
\text { about }\end{array}$ & $\begin{array}{l}\text { D - Co } \\
\text { Vv - En } \\
\text { ar; Li - } \\
\text { ts; P - }\end{array}$ & & & $\begin{array}{l}\text { uglas; } \\
\text { lental; } \\
\text { ock; M } \\
\text { eetric; }\end{array}$ & & $\begin{array}{l}- \text { Crc } \\
- \text { Fee } \\
\text { Materi }\end{array}$ & $\begin{array}{l}\text { op; } \\
\text { ed; } \\
\text { ial; } \\
\text { ta; }\end{array}$ & $\begin{array}{l}\text { D - } \\
\text { Fer } \\
\text { M- } \\
\text { R- }\end{array}$ \\
\hline
\end{tabular}




\begin{tabular}{|c|c|c|c|c|c|c|c|c|c|c|c|c|c|c|c|c|c|}
\hline \multirow{4}{*}{$\begin{array}{r}\text { References } \\
\text { Chang \& Mishra (2011) }\end{array}$} & \multirow{2}{*}{\multicolumn{8}{|c|}{ Inputs }} & \multirow{3}{*}{\multicolumn{3}{|c|}{ Outputs }} & \multicolumn{6}{|c|}{ Metrics } \\
\hline & & & & & & & & & & & & \multicolumn{2}{|c|}{ NP } & \multicolumn{4}{|c|}{$\mathbf{P}$} \\
\hline & \multicolumn{7}{|c|}{ Inventory and costs } & \multirow[t]{2}{*}{$\mathrm{AH}^{*}$} & & & & $\mathrm{D}$ & \multirow[t]{2}{*}{$\mathrm{S}$} & $\mathrm{D}$ & \multicolumn{3}{|c|}{$\mathrm{S}$} \\
\hline & $\mathrm{x}$ & $x$ & $x$ & & $x$ & $x$ & & & $x$ & & & $x$ & & & & & \\
\hline Chidmi et al. (2010) & $\mathrm{x}$ & $x$ & $x$ & & $\mathrm{x}$ & & $\mathrm{Cr}, \mathrm{Li}$ & & $x$ & & & & & & $x$ & & \\
\hline Cuesta (2000) & & $x$ & $x$ & & \begin{tabular}{l|l}
$x$ & $x$ \\
\end{tabular} & & & & $x$ & & & & & & & $x$ & \\
\hline D'Haese et al. (2009) & & $\mathrm{x}$ & & & \begin{tabular}{|l|l|}
$x$ & $x$ \\
\end{tabular} & $x$ & $\mathrm{Li}$ & & $\mathrm{x}$ & & & $x$ & & & & & \\
\hline Dawson \& White (1990) & & & $x$ & $x$ & $\mathrm{x}$ & & $\mathrm{Ca}, \mathrm{E}, \mathrm{R}$ & & $x$ & & & & & & $x$ & & \\
\hline Dawson et al. (1991) & & & & & \begin{tabular}{l|l}
$x$ & $x$ \\
\end{tabular} & & Al, Fer & & $x$ & & & & & & $x$ & & \\
\hline Del Corral et al. (2011) & & $x$ & $x$ & $x$ & \begin{tabular}{l|l|l}
$x$ & $x$ \\
\end{tabular} & & $\mathrm{Ca}, \mathrm{O}$ & & $x$ & & & & & & & $x$ & \\
\hline Dong et al. (2013) & $x$ & & $x$ & & $\mathrm{x}$ & $x$ & & $x$ & $x$ & & & & & & $\mathrm{x}$ & & \\
\hline Fogarasi \& Latruffe (2007a) & $x$ & & & & \begin{tabular}{l|l}
$x$ & $x$ \\
\end{tabular} & & IC & & $x$ & & $x$ & $x$ & & & & & \\
\hline Fogarasi \& Latruffe (2007b) & $x$ & & & & \begin{tabular}{l|l}
$x$ & $x$ \\
\end{tabular} & & IC, Li & & $x$ & & $x$ & $x$ & & & & & \\
\hline Fogarasi \& Latruffe (2009) & $x$ & & & & \begin{tabular}{l|l}
$x$ & $x$ \\
\end{tabular} & & IC, Li & & $x$ & & $x$ & $x$ & & & & & \\
\hline Fraser \& Cordina (1999) & & $x$ & $x$ & & \begin{tabular}{l|l}
$x$ & $x$ \\
\end{tabular} & & W, Fer & & $x$ & & & $x$ & & & & & \\
\hline Gelan \& Muriithi (2010) & & & $x$ & $x$ & $\mathrm{x}$ & & $\mathrm{Ca}, \mathrm{W}$ & $x$ & $x$ & & $x$ & $x$ & & & & & \\
\hline Ghosh et al. (1994) & $x$ & $\mathrm{x}$ & $x$ & & $\mathrm{x}$ & & & & $x$ & & & & & & $x$ & & \\
\hline Gonçalves et al. (2008) & & & $x$ & & $\mathrm{x}$ & & En,De & $x$ & $x$ & & $x$ & $x$ & & & & & \\
\hline Hadley (2006) & $x$ & $x$ & $\mathrm{x}$ & & $x \mid x$ & $x$ & $\begin{array}{l}\text { Cr, Q, Se, Fer, } \\
\text { O }\end{array}$ & $x$ & & & $x$ & & & & & $x$ & \\
\hline Hadley et al. (2001) & $x$ & $x$ & $x$ & & \begin{tabular}{l|l}
$x$ & $x$ \\
\end{tabular} & $x$ & $\mathrm{Cr}$ & $x$ & & & $x$ & & & & & $x$ & \\
\hline Haghiri et al. (2004) & & $\mathrm{x}$ & $x$ & & \begin{tabular}{l|l}
$x$ & $x$ \\
\end{tabular} & & & & $x$ & & & & $\mathrm{x}$ & & & & \\
\hline Hallam \& Machado (1996) & $x$ & $\mathrm{x}$ & $x$ & & $x$ & $x$ & Se, IC & & $x$ & & & & & $x$ & & $x$ & \\
\hline Hansson (2007) & $x$ & & & $x$ & $\mathrm{x}$ & & $\begin{array}{l}\text { Cr, En, Se, } \\
\text { Fer, Li }\end{array}$ & & $x$ & & & $x$ & & & & & \\
\hline Hansson \& Öhlmér (2008) & $x$ & & & $x$ & $\mathrm{x}$ & & En, Se, Fer & & $x$ & $\begin{array}{l}\text { Cr, Li, } \\
\text { O }\end{array}$ & & $x$ & & & & & \\
\hline \multicolumn{18}{|c|}{$\begin{array}{l}\text { A - Land; AH - Animal Health; Al - Area Irrigated; B - Butterfat; C - Cow; Ca - Cattle or animal; CD - Cobb-Douglas; Cr - Crop; D - } \\
\text { Deterministic; De - Depreciation; DEA - Data Envelopment Analysis; E - Equipment; En - Energy, Env - Environmental; Fe - Feed; Fer } \\
\text { - Fertilizer; Fo - Fodder; IC - Intermediate Consuption; II - Intermediate Inputs; K - Capital; L - Labour; Li - Livestock; M - Material; M - } \\
\text { Milk; NP - Non-Parametric; O - Others; OC - Other Costs; OI - Others Incomes; Ou - Others Outputs; P - Parametric; Q - Quota; R - } \\
\text { Rent; S - Stochastic; Se - Seed; TL - Translog; W - Water. }\end{array}$} \\
\hline \multicolumn{18}{|c|}{ *artificial insemination, breeds, hormone bst, services, pasture, veterinary } \\
\hline
\end{tabular}




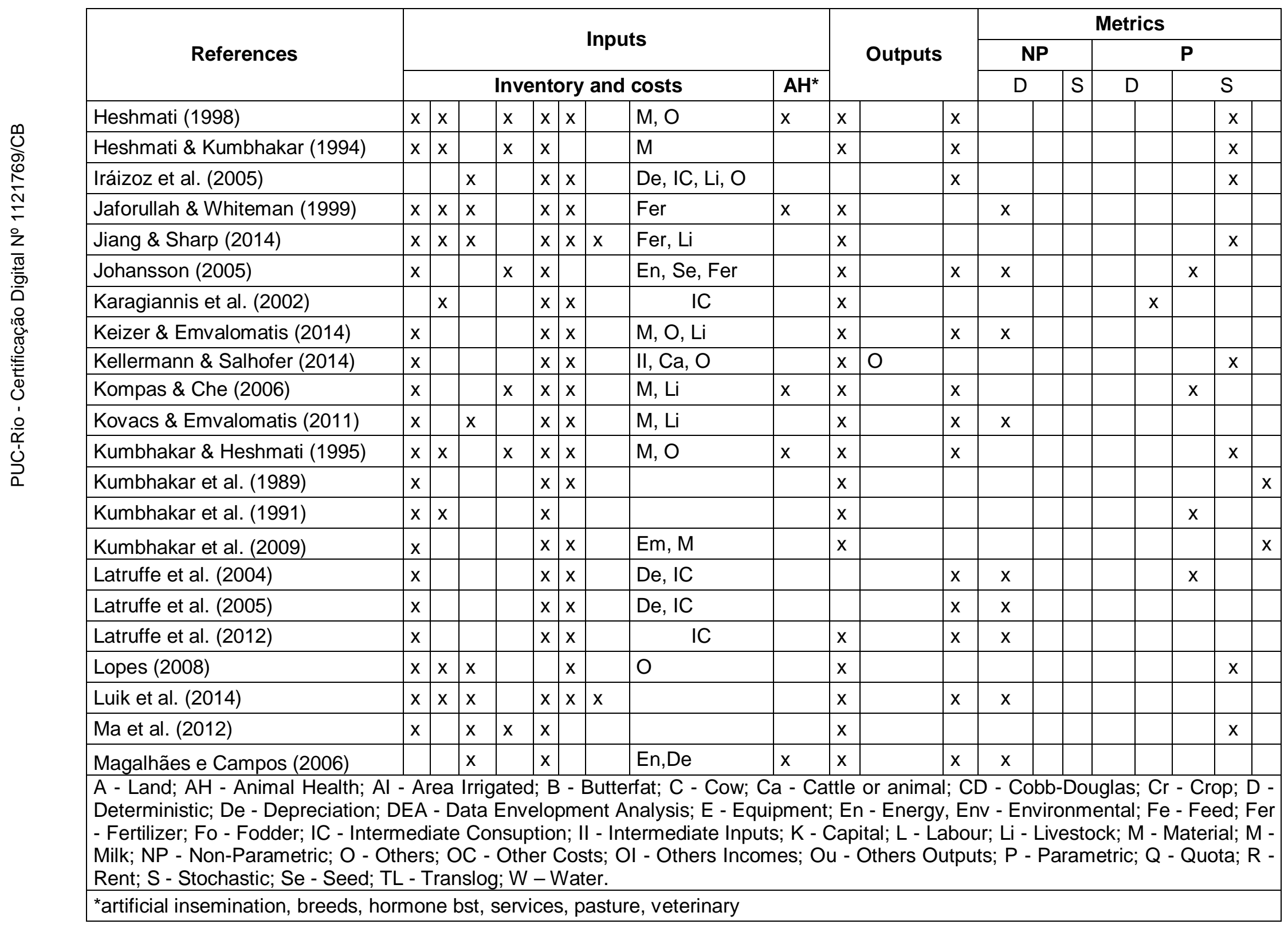




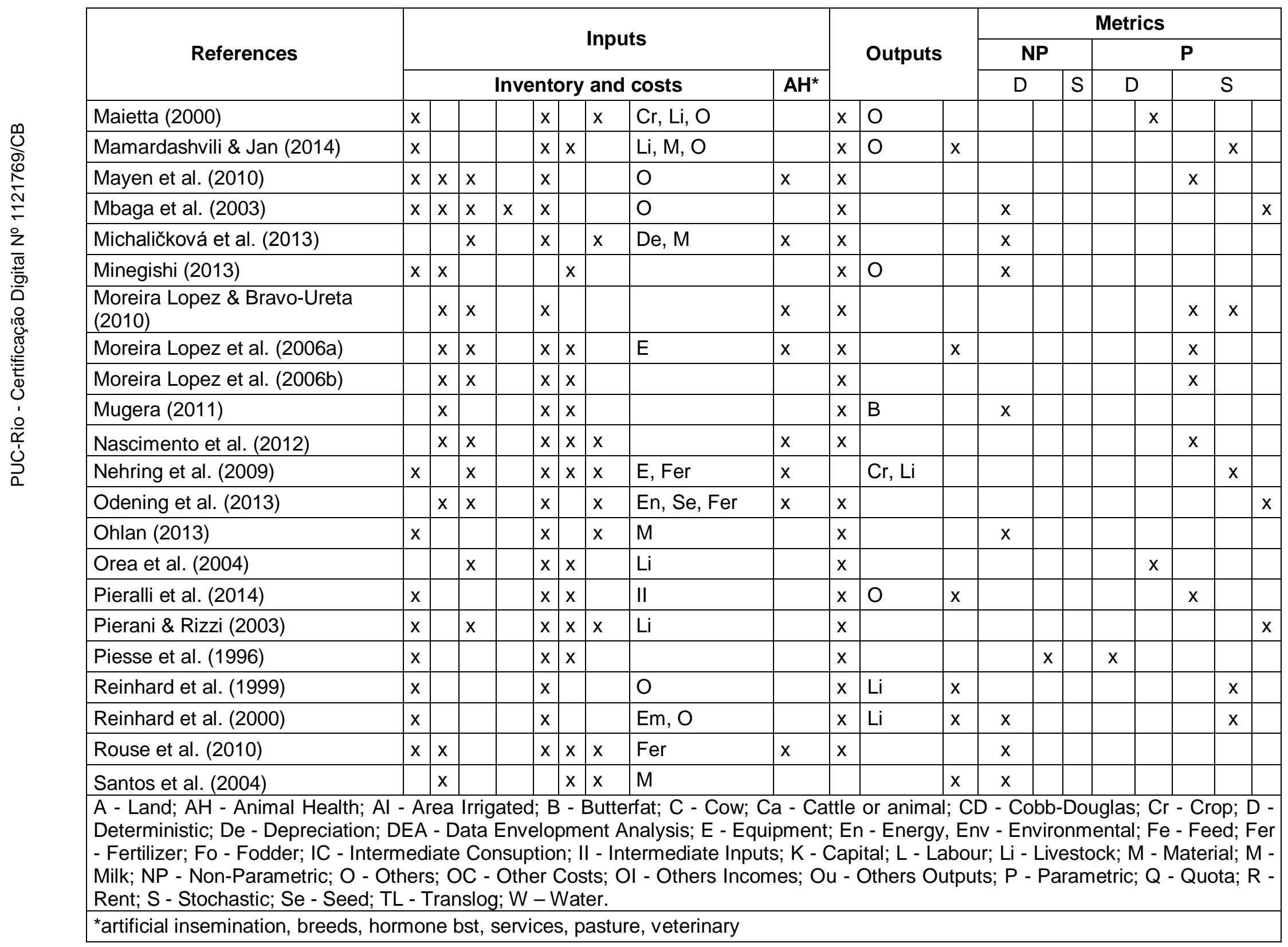




\begin{tabular}{|c|c|c|c|c|c|c|c|c|c|c|c|c|c|c|c|c|c|c|}
\hline \multirow{4}{*}{$\begin{array}{r}\text { References } \\
\text { Santos et al. (2005) }\end{array}$} & \multirow{2}{*}{\multicolumn{8}{|c|}{ Inputs }} & \multirow{3}{*}{\multicolumn{3}{|c|}{ Outputs }} & \multicolumn{7}{|c|}{ Metrics } \\
\hline & & & & & & & & & & & & \multicolumn{3}{|c|}{ NP } & \multicolumn{4}{|c|}{$\mathbf{P}$} \\
\hline & \multicolumn{7}{|c|}{ Inventory and costs } & \multirow[t]{2}{*}{$\mathrm{AH}^{*}$} & & & & \multicolumn{2}{|c|}{$\mathrm{D}$} & \multirow[t]{2}{*}{$\mathrm{S}$} & $\mathrm{D}$ & \multicolumn{3}{|c|}{$\mathrm{S}$} \\
\hline & & $x$ & & & \begin{tabular}{l|l}
$x$ & $x$
\end{tabular} & $x$ & & & $x$ & & & $x$ & & & & & & \\
\hline Sauer \& Latacz-Lohmann (2013) & & $x$ & & $x$ & \begin{tabular}{l|l}
$x$ & $x$ \\
\end{tabular} & & De, IC & $x$ & $x$ & $\mathrm{Li}$ & $x$ & & & & & & $x$ & \\
\hline Shortall \& Barnes (2013) & $x$ & $\mathrm{x}$ & $x$ & & \begin{tabular}{l|l}
$x$ & $x$ \\
\end{tabular} & & $\mathrm{Ca}$, Fer & & $x$ & & & $x$ & & & & & & \\
\hline Singbo \& Larue (2014) & $x$ & & $x$ & & \begin{tabular}{l|l}
$x$ & $x$ \\
\end{tabular} & & $E$ & & $x$ & & $x$ & & & & & & $x$ & \\
\hline Skevas et al. (2014) & $x$ & & & & \begin{tabular}{l|l}
$x$ & $x$ \\
\end{tabular} & & $\mathrm{Li}, \mathrm{O}$ & & $x$ & & $x$ & & & & & & $x$ & \\
\hline Sousa et al. (2012) & $x$ & $\mathrm{x}$ & & & \begin{tabular}{|l|l|l}
$x$ & $x$ \\
\end{tabular} & & $\mathrm{E}$ & & $x$ & & $x$ & $x$ & & & & & & \\
\hline Steeneveld et al. (2012) & & $\mathrm{x}$ & $x$ & & \begin{tabular}{l|l}
$x$ & $x$ \\
\end{tabular} & & $\mathrm{De}, \mathrm{E}, \mathrm{Em}, \mathrm{W}$ & $x$ & $x$ & & $x$ & $x$ & & & & & & \\
\hline Tauer (1993) & & $\mathrm{x}$ & $x$ & & $x$ & $x$ & & & $x$ & & & $x$ & & & & & & \\
\hline Tauer (1998) & & & $x$ & & $x$ & $x$ & Cr, E, Li & & $x$ & $\mathrm{O}$ & & & $\mathrm{x}$ & & & & & \\
\hline Tauer \& Belbase (1987) & & $x$ & $x$ & & $x$ & $x$ & Cr, E, Li & & & & $x$ & & & & $x$ & & & \\
\hline Thomas \& Tauer (1994) & & & $x$ & & $x$ & $x$ & $\begin{array}{l}\mathrm{Cr}, \mathrm{De}, \mathrm{E}, \mathrm{En}, \\
\mathrm{Li}\end{array}$ & $x$ & $x$ & & & & $x$ & & & & & \\
\hline Tran \& Tsionas (2013) & $x$ & & $x$ & & \begin{tabular}{l|l}
$x$ & $x$ \\
\end{tabular} & \begin{tabular}{l|l}
$x$ \\
\end{tabular} & $\mathrm{Ca}$ & & $x$ & & & & & & & & $x$ & \\
\hline Tsionas (2007) & & $x$ & $x$ & & \begin{tabular}{l|l}
$x$ & $x$
\end{tabular} & & O & & $x$ & & & & & & & $x$ & & \\
\hline Uddin et al. (2014) & & $\mathrm{x}$ & & & \begin{tabular}{l|l}
$x$ & $x$ \\
\end{tabular} & $x$ & & & $x$ & & & & & & & $x$ & & \\
\hline Van der Voort et al. (2014) & & $x$ & $x$ & & $x$ & & & $x$ & $x$ & & & & & & & $x$ & $x$ & \\
\hline Wang (2001) & $x$ & $\mathrm{x}$ & $x$ & & $\mathrm{x}$ & & & & $x$ & & & & & & & $x$ & & \\
\hline Xiaohua (2012) & & $\mathrm{x}$ & & & $x$ & & IC & & $x$ & & & & & & & $x$ & & \\
\hline Yélou et al. (2010) & $x$ & $x$ & $x$ & $x$ & $x$ & & & & $x$ & & & & & & & $x$ & $x$ & \\
\hline \multicolumn{19}{|c|}{$\begin{array}{l}\text { A - Land; AH - Animal Health; Al - Area Irrigated; B - Butterfat; C - Cow; Ca - Cattle or animal; CD - Cobb-Douglas; Cr - Crop; D - } \\
\text { Deterministic; De - Depreciation; DEA - Data Envelopment Analysis; E - Equipment; En - Energy, Env - Environmental; Fe - Feed; Fer } \\
\text { - Fertilizer; Fo - Fodder; IC - Intermediate Consuption; II - Intermediate Inputs; K - Capital; L - Labour; Li - Livestock; M - Material; M - } \\
\text { Milk; NP - Non-Parametric; O - Others; OC - Other Costs; OI - Others Incomes; Ou - Others Outputs; P - Parametric; Q - Quota; R - } \\
\text { Rent; S - Stochastic; Se - Seed; TL - Translog; W - Water. }\end{array}$} \\
\hline *artificial insemination, breeds, hor & & רe b & $\overline{s t, s}$ & servi & ces, & past & e, veterinary & & & & & & & & & & & \\
\hline
\end{tabular}


Most TE outputs are milk-related, with a large concentration on milk production (53 cases) and income from milk (M) (31 cases), followed by other types of incomes (OI), such as cows and meat sold (Reinhard et al., 1999; Reinhard et al., 2000; Kompas \& Che, 2006; Lopes, 2008; Latruffe et al., 2012; Pieralli et al., 2014). Among other outputs, Livestock (Li) and crop (Cr) prevail (Tauer, 1993; Tauer, 1998; Mbaga et al., 2003; Hansson \& Öhlmér, 2008; Barnes et al., 2011; Mugera, 2011).

Measurement techniques are non-parametric (41 cases) and parametric (72 cases). One paper may use more than one technique. DEA was the method of choice among the non-parametric studies (90.2\%). Among parametric studies, the Translog functional form prevails (50\%), followed by the Cobb-Douglas function (44\%). Fifty studies applied deterministic models and 63 have reported using stochastic models. Despite the possibility of a direct impact of the measurement technique on TE results, there is no agreement about the most appropriate methodology for a given situation (Olesen et al., 1996), which remains a matter of ongoing debate (Bravo-Ureta et al., 2007).

\subsection{3}

Discussions

This review integrates the findings of 103 published papers about TE in dairy farms. Mean TE, its determinants and measurement techniques were reviewed and synthesized. One striking feature that emerges from the literature is the lack of consensus about measurement techniques and determinants of TE, which remains an open debate. The study offers a research synthesis framework as a structuring tool to assemble TE descriptors from the extant literature. It makes three important contributions to the estimation of TE and its determinants in dairy farms. First, it complements and extends previous literature reviews. Second, it offers a research synthesis framework for the analysis of TE in dairy farms. Third, it synthesizes results as researchable and verifiable propositions. 
The research synthesis can be of assistance to dairy farmers, policy makers and researchers. For dairy farmers and policy makers, it emphasizes the positive effect of public policies on mean TE, such as human resources development through extension services. The fact that larger farms seem to be comparatively better than small farms in terms of TE stresses the need for public policies aiming at increasing mean TE in this segment. In addition, available evidence shows that best management practices can be benchmarked and lead to substantive gains in productivity. Finally, dairy farms should be located in favourable contexts regarding climate, altitude and soil quality.

Despite the growing literature on the subject, TE in dairy farms could benefit from future research in the following three areas: analysis of the impact of different measurement techniques on resulting mean TE; investigation of the variables that can mediate or moderate the relationship between determinants and mean TE; development of benchmarks based on best management practices.

Dairy farms are important components of rural production all over the world. Measuring efficiency and explaining their determinants are the first steps to achieve important economic gains and to remain competitive in nowadays markets. The analysis of benchmarks (best practices) may lead to substantial resource savings, with important implications to improve management, and therefore the productivity and competitiveness of dairy farms.

The research synthesis next step is the analysis of the effects that some determinants (e.g., measurement technique, functional form, type of data, dimensionality, geographical region, income level and farm size) has on MTE, on the same 103 papers. The hypothesis is that the variation in the MTE reported in the literature can be explained by these attributes. The propositions (1, 2, 3, 5 and 6) related are contained in these hypotheses. 


\section{3}

\section{Meta-regression analysis}

This subsection presents meta-regression analysis in three subsections: data description and hypothesis, results of the statistical model and discussions. The main results presented within this subsection were adapted in a paper that was accepted for publication (Mareth et al., 2015).

\subsection{4}

\section{Data description and hypothesis}

A list of all the papers included in this review, by authors' names, year of publication, country, sample size and mean TE, is presented in Table 5, regrouped according to the methodology used in the estimates.

Table 5: Overview of empirical studies of TE in dairy farms

\begin{tabular}{llrr}
\hline \multicolumn{1}{c}{ References } & \multicolumn{1}{c}{ Country } & $\begin{array}{c}\text { Sample } \\
\text { Size }\end{array}$ & Mean TE \\
\hline \hline I - Non-parametric & & & \\
Deterministic frontier & & & \\
Ang \& Oude Lansink (2014) & Belgian & 254 & 92.9 \\
Asmild et al. (2003) & Netherlands & 1808 & 80.5 \\
Balcombe et al. (2006) & Australia & 241 & 65.0 \\
Barnes et al. (2011) & UK & 80 & 84.0 \\
Bojnec \& Latruffe (2008) & Slovenia & 130 & 100.0 \\
Chang \& Mishra (2011) & USA & 1593 & 58.0 \\
D'Haese et al. (2009) & France & 34 & 93.9 \\
Fogarasi \& Latruffe (2007a) & France, Hungary & 335 & 77.0 \\
Fogarasi \& Latruffe (2007b) & France, Hungary & 719 & 84.4 \\
Fogarasi \& Latruffe (2009) & France, Hungary & 7126 & 80.7 \\
Fraser \& Cordina (1999) & Australia & 50 & 88.5 \\
Gelan \& Muriithi (2010) & Africa & 371 & 48.8 \\
Gonçalves et al. (2008) & Brazil & 771 & 78.1 \\
Hansson (2007) & Sweden & 507 & 86.9 \\
Hansson \& Öhlmér (2008) & Sweden & 507 & 87.7 \\
Jaforullah \& Whiteman (1999) & New Zealand & 264 & 89.0 \\
Johansson (2005) & Sweden & 1940 & 77.0 \\
Keizer \& Emvalomatis (2014) & Netherlands & 196 & 99.0 \\
Kovacs \& Emvalomatis (2011) & Germany, Hungary, Netherlands & 1254 & 84.2 \\
Latruffe et al. (2004) & Netherlands & 222 & 64.0 \\
Latruffe et al. (2005) & Netherlands & 199 & 69.8
\end{tabular}


Latruffe et al. (2012)

Luik et al. (2014)

Magalhães \& Campos (2006)

Mbaga et al. (2003)

Michaličková et al. (2013)

Minegishi (2013)

Mugera (2011)

Ohlan (2013)

Piesse et al. (1996)

Reinhard et al. (2000)

Rouse et al. (2010)

Santos et al. (2004)

Santos et al. (2005)

Shortall \& Barnes (2013)
France, Hungary

Estonian

Brazil

Canada

Slovakia

Maryland

USA

India

Slovenia

Netherlands

New Zealand

Brazil

Brazil

Scotland
$5298 \quad 73.6$

$147 \quad 87.9$

$40 \quad 79.4$

$1143 \quad 93.6$

$83 \quad 96.0$

$63 \quad 82.6$

$371 \quad 69.1$

$1100 \quad 72.0$

$272 \quad 93.0$

$1535 \quad 79.7$

$120 \quad 85.7$

$28 \quad 88.8$

$17 \quad 88.2$

$61 \quad 69.5$

\begin{tabular}{llrr}
\hline \multicolumn{1}{c}{ References } & Country & $\begin{array}{r}\text { Sample } \\
\text { Size }\end{array}$ & Mean TE \\
\hline \hline Sousa et al. (2012) & Brazil & 500 & 54.5 \\
Steeneveld et al. (2012) & Germany & 400 & 77.0 \\
Tauer (1993) & USA & 395 & 78.3 \\
Tauer (1998) & USA & 630 & 91.8 \\
Thomas \& Tauer (1994) & USA & 125 & 89.2 \\
Mean & & & 81.0 \\
& & & \\
Sochastic frontier & & & \\
Haghiri et al. (2004) & Canada, USA & 6836 & 58.2 \\
Mean & & & 58.2 \\
& & & \\
II - Parametric & & & \\
Deterministic frontier & USA & 1072 & 76.5 \\
Ahmad \& Bravo-Ureta (1996) & Spain & 196 & 70.0 \\
Alvarez \& Arias (2004) & Spain & 410 & 72.0 \\
Álvarez \& Gonzalez (1999) & USA & 404 & 63.3 \\
Bravo-Ureta \& Rieger (1990) & Portugal & 340 & 62.5 \\
Hallam \& Machado (1996) & UK & 2147 & 77.6 \\
Karagiannis et al. (2002) & Italy & 533 & 55.0 \\
Maietta (2000) & Spain & 445 & 65.9 \\
Orea et al. (2004) & Slovenia & 272 & 57.5 \\
Piesse et al. (1996) & USA & 432 & 69.3 \\
Tauer \& Belbase (1987) & & & 67.0 \\
Mean & & &
\end{tabular}

Sochastic frontier

Ahmad \& Bravo-Ureta (1996)

USA

$1072 \quad 81.0$

UK

Angón et al. (2013)

Argentina

$215 \quad 84.5$

Ecuador

$47 \quad 35.0$

Bailey et al. (1989)

Balcombe et al. (2006)

Bardhan \& Sharma (2013)

Barnes (2008)

Australia

$68 \quad 78.1$

India

$241 \quad 81.8$

UK

Australia

$60 \quad 89.5$

$1008 \quad 72.0$

$336 \quad 70.7$ 
Bojnec \& Latruffe (2008)
Bravo-Ureta \& Rieger (1990)
Bravo-Ureta \& Rieger (1991)
Bravo-Ureta et al. (2008)
Brümmer \& Loy (2000)
Brümmer et al. (2002)
Cabrera et al. (2010)
Chidmi et al. (2010)
Cuesta (2000)
Dawson \& White (1990)
Dawson et al. (1991)
Del Corral et al. (2011)
Dong et al. (2013)
Ghosh et al. (1994)

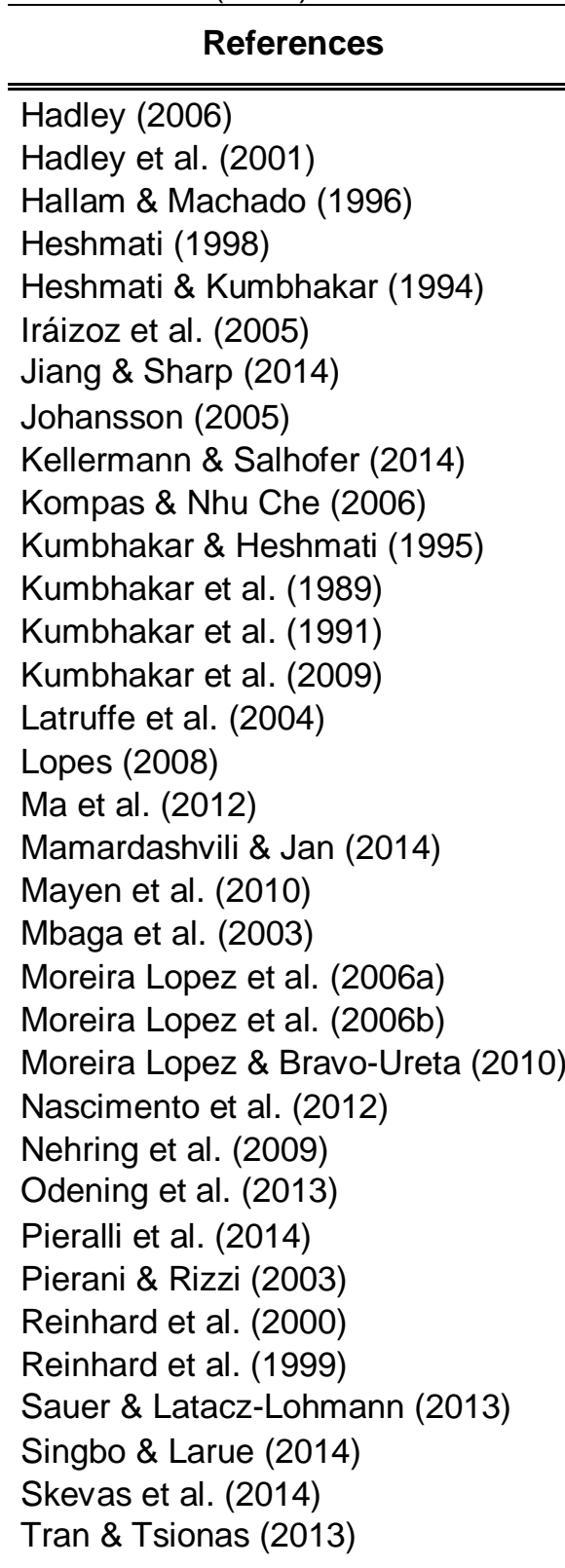

Slovenia
USA
USA
Argentina, Chile, Uruguay
Germany
Germany, Poland, Netherlands
USA
USA
Spain
UK
UK
Spain
USA
USA

130

$404 \quad 83.9$

$511 \quad 83.0$

$147 \quad 84.3$

$3000 \quad 96.0$

$300 \quad 86.9$

$273 \quad 88.0$

$909 \quad 95.4$

$410 \quad 82.7$

$306 \quad 85.7$

$22 \quad 86.0$

$144 \quad 89.6$

$1330 \quad 79.0$

$145 \quad 91.9$

\begin{tabular}{lrr} 
UK & 1431 & 89.7 \\
UK & 4775 & 91.6 \\
Portugal & 340 & 81.0 \\
Sweden & 3979 & 94.5 \\
Sweden & 600 & 82.2 \\
Spain & 2594 & 84.3 \\
New Zealand & 824 & 82.0 \\
Sweden & 1940 & 55.0 \\
Germany & 1142 & 95.7 \\
Australia & 415 & 87.6 \\
Sweden & 1425 & 84.7 \\
USA & 89 & 78.9 \\
USA & 519 & 70.4 \\
Finland & 279 & 79.6 \\
Netherlands & 250 & 80.5 \\
Portugal & 335 & 84.0 \\
China & 331 & 75.5 \\
Switzerland & 507 & 94.0 \\
USA & 1482 & 82.7 \\
Canada & 1143 & 94.8 \\
Argentina & 82 & 77.5 \\
Chile & 92 & 72.2 \\
Argentina, Chile, Uruguay & 164 & 77.5 \\
Brazil & 875 & 83.0 \\
USA & 8263 & 79.0 \\
Germany & 1269 & 83.7 \\
Germany & 2403 & 80.7 \\
Italy & 533 & 66.2 \\
Netherlands & 1535 & 89.5 \\
Netherlands & 1545 & 89.4 \\
Germany & 2700 & 81.7 \\
Canada & 1495 & 87.6 \\
Netherlands & 2105 & 86.0 \\
Norway & 714 & 76.1 \\
& & \\
\hline
\end{tabular}


Tsionas (2007)

Uddin et al. (2014)

Van der Voort et al.(2014)

Wang (2001)

Xiaohua (2012)

Yélou et al. ( (2010)

Mean

Overall Mean
Spain $\quad 80 \quad 70.0$

Bangladesh $\quad 180 \quad 83.0$

Belgian $202 \quad 84.5$

$\begin{array}{lll}\text { USA } & 70 & 80.3\end{array}$

$\begin{array}{lll}\text { China } & 550 & 75.8\end{array}$

$\begin{array}{lll}\text { Canada } & 3322 & 96.2\end{array}$

Among the 103 papers of Table 5, non-parametric methods were applied in 41 cases and parametric methods were applied to 72 cases. The sum of 113 nonparametric and parametric studies is larger than the number of papers because both techniques were implemented in some studies. In the cases when both methods were used they were calculated independently of each other and both parametric and nonparametric results were reported separately. This is important because it allowed the inclusion of separate estimates in the meta-regression from the same sample, one using a parametric estimate and another one using non-parametric methods. In $90.2 \%$ of the non-parametrics studies, Data Envelopment Analysis (DEA) was used. In the parametric studies, the translog functional form was prevalent, followed by the CobbDouglas function, with respectively, $50 \%$ and $44 \%$ of cases. Fifty studies applied deterministic models and 63 resorted to stochastic models. This same pattern was observed in Rivas (2003) and Bravo-Ureta et al. (2007).

Table 6 summarizes the methodological features of these 103 studies, which totalled 531 distributions for meta-regression analysis. This number of distributions of MTE in dairy farms compares favourably with the 105 distributions analysed by Rivas (2003), 329 distributions regressed by Moreira Lopez (2006) and 178 distributions included in the meta-regression by Bravo-Ureta et al. (2007). 
Table 6: Average mean TE (AMTE) by methodological characteristics

\begin{tabular}{|c|c|c|c|c|c|c|c|c|}
\hline \multirow{2}{*}{ Category } & \multirow{2}{*}{$\begin{array}{l}N^{\circ} \text {. of } \\
\text { cases }\end{array}$} & \multicolumn{3}{|c|}{ Deterministic } & \multicolumn{3}{|c|}{ Stochastic } & \multirow{2}{*}{ AMTE } \\
\hline & & Avg. & Max. & Min. & Avg. & Max. & Min. & \\
\hline \multicolumn{9}{|l|}{ Approach } \\
\hline Parametric & 270 & 67.0 & 77.6 & 55.0 & 81.7 & 96.2 & 35.0 & 79.7 \\
\hline Non-parametric & 261 & 81.0 & 100.0 & 48.8 & 58.2 & 58.2 & 58.2 & 80.4 \\
\hline \multicolumn{9}{|l|}{ Data } \\
\hline Panel & 430 & 78.9 & 100.0 & 55.0 & 80.8 & 96.0 & 35.0 & 80.0 \\
\hline Cross sectional & 101 & 77.3 & 93.9 & 48.8 & 83.8 & 95.2 & 70.4 & 80.4 \\
\hline \multicolumn{9}{|l|}{ Functional form } \\
\hline Cobb-Douglas & 88 & 66.6 & 76.5 & 57.5 & 79.2 & 96.0 & 35.0 & 77.7 \\
\hline Translog & 143 & 70.1 & 81.3 & 55.0 & 85.6 & 96.0 & 72.0 & 82.6 \\
\hline Data Envelopment Analysis & 235 & 80.1 & 100.0 & 48.8 & - & - & - & 80.1 \\
\hline Others & 65 & 91.3 & 93.0 & 89.2 & 73.7 & 95.2 & 56.4 & 78.1 \\
\hline AMTE & & & 78.2 & & & 81.3 & & 79.9 \\
\hline Number of cases & & & 296 & & & 235 & & 531 \\
\hline Number of studies & & & 50 & & & 63 & & 113 \\
\hline
\end{tabular}

In general, most studies used parametric models, stochastic frontiers, panel data and Translog functions. The average mean TE (AMTEs) for all deterministic models is $78.2 \%$ compared with $81.3 \%$ for all stochastic models, which is consistent with results from Rivas (2003), Moreira López (2006) and Bravo-Ureta et al. (2007). A comparison of AMTEs between the parametric and non-parametric estimates shows that the former are lower (79.6\%) than the latter (80.8\%), which is consistent with Rivas (2003) and Bravo-Ureta et al. (2007). The opposite pattern is observed in Moreira López (2006). The inclusion of parametric and non-parametric methods for the same sample when both estimates were reported would tend to influence MTE upwards. Therefore, the meta-regression commented on Subsection 3.2 below could have a slightly higher intercept, although there are no reasons to expect major changes in the slope of the regression plane. The effect of the method of estimation on MTE is commented further in relation to Hypothesis 1, in Subsection 3.2.

The Translog form yields a higher AMTE than the Cobb-Douglas function for both the deterministic and the stochastic models, which is consistent with results from Rivas (2003). The opposite pattern is observed for the deterministic models in the studies by Moreira López (2006) and Bravo-Ureta et al. (2007), where the CobbDouglas form yields a higher AMTE than the Translog. DEA was used in $90.2 \%$ of 
the non-parametric studies (235 cases), resulting in a MTE of 80.1\%. Finally, Table 6 shows that studies using panel data presented a lower AMTE (80\%) than studies with cross-sectional data (80.4\%) for both deterministic and stochastic models. This result is consistent with the findings of Rivas (2003).

Table 7 summarizes the AMTE measures according to the geographical region and the income level of the country where the studies were conducted. National income was drawn from The World Bank indicators (World Bank, 2005). The Gross National Income (GNI) per capita was used as a proxy. The GNI is converted to US dollars using the World Bank Atlas method and divided by the mid-year population to yield the per capita index. It represents the sum of value added by all resident producers plus taxes (less subsidies) "not included in the valuation of output plus net receipts of primary income from abroad” (World Bank, 2005). The year of 2005 was chosen instead of more recent data available for the same national income indicator because it roughly corresponds to the mid period of the series of MTE used in the regression. Thus, it should be more representative of the conditions prevailing at the time when most of the survey data used for the other variable in the regressions was collected.

Table 7: Average Mean TE (AMTE) by geographical region and country's income level

\begin{tabular}{|c|c|c|c|c|c|c|c|c|}
\hline \multirow{2}{*}{$\begin{array}{l}\text { Geographical region } \\
\text { and income level }\end{array}$} & \multirow{2}{*}{$\mathrm{N}^{\circ}$. of cases } & \multicolumn{3}{|c|}{ Deterministic } & \multicolumn{3}{|c|}{ Stochastic } & \multirow{2}{*}{ AMTE } \\
\hline & & Avg. & Max. & Min. & Avg. & Max. & Min. & \\
\hline Alllica & $\perp$ & & 48.8 & 48.8 & & - & - & 0.0 \\
\hline Asia & 100 & & 72.0 & 72.0 & 1.0 & 89.5 & 75.5 & \\
\hline L. Am & & 7.8 & 88.8 & 54.5 & 5.1 & 87.0 & 35.0 & 3.1 \\
\hline N. Ame & 110 & 7.2 & 93.6 & 58.0 & 1.7 & 6.2 & 56.4 & .0 \\
\hline $\mathrm{E}$ & & 3 & 100.0 & 57.5 & 2.9 & 0 & 9 & 1 \\
\hline h & 225 & 1 & 99.0 & 55.0 & 2.4 & 94.5 & 55.0 & 0.7 \\
\hline $\mathrm{L}$ & 9 & 0.4 & 72.0 & 48.8 & 6.3 & 89.5 & 83.0 & 3 \\
\hline $\mathrm{L}$ & 39 & 77.8 & 88.8 & 54.5 & 78.1 & 83.0 & 75.5 & 77.9 \\
\hline UMICs & 4 & 86.3 & 96.0 & 73.5 & 73.6 & 87.0 & 35.0 & 80.0 \\
\hline $\mathrm{HICs}$ & 351 & 78.1 & 100.0 & 55.0 & 82.2 & 96.2 & 51.9 & 80.4 \\
\hline \multicolumn{9}{|c|}{$\begin{array}{l}\text { LICs: lower-income countries (Bangladesh, India, Kenya, Rwanda and Uganda), LMICs: } \\
\text { lower middle-income countries (China, Brazil and Ecuador), UMICs: upper middle-income } \\
\text { countries (Argentina, Chile, Estonian, Hungary, Slovakia and Uruguay), and HICs: higher- } \\
\text { income countries (Australia, Belgian, Canada, Finland, France, Germany, Greece, Italy, the } \\
\text { Netherlands, New Zealand, Norway, Poland, Portugal, Republic of Korea, Scotland, Slovenia, } \\
\text { Spain, Sweden, Switzerland, the United Kingdom and the United States) (World Bank, 2005). } \\
\text { * North America includes the United States and Canada. }\end{array}$} \\
\hline
\end{tabular}


The largest number of cases is observed for Western Europe \& Oceania (225), followed by North America (United States and Canada, 110), Asia (100), Latin America and the Caribbean (56), Eastern Europe (39) and Africa (1).

For stochastic and deterministic studies combined, AMTE ranks from 83.1\% in Eastern Europe to 80.7\% in Western Europe \& Oceania, 80.0\% in North America, 79.2\% in Asia, $76.1 \%$ in Latin America and a low $48.8 \%$ in Africa (one study only). However, when stochastic and deterministic models are used, a different ranking of AMTE emerges. The AMTE ranking for stochastic models from top-down: Eastern Europe tops the list, followed by Western Europe \& Oceania, North America, Asia and Latin America. For deterministic studies, AMTE ranking is: Eastern Europe, Western Europe \& Oceania, Latin America, North America, Asia and Africa. It is interesting to note that a fourth AMTE ranking was reported by Moreira Lopez (2006) and Bravo-Ureta et al. (2007), from higher to lower: Asia, Western Europe \& Oceania.

The AMTE ranking by income level for deterministic and stochastic methods combined is Higher-Income Countries (HICs) and Upper Middle-Income Countries (UMICs), followed by Lower Middle-Income Countries (LMICs) and lower-income countries (LICs), in that order. However, for deterministic frontier methods, higher MTE is found for UMICs (86.3\%) and HICs (78.1\%) countries, followed by LMICs (77.8\%) and LICs (60.0\%) countries. For stochastic models, higher MTE is found for LICs (86.3\%) and HICs (82.2\%) countries, followed by LMICs (78.1\%) and UMICs (73.6\%) countries. Bravo-Ureta et al. (2007) found the AMTE ranking different for deterministic and stochastic methods combined: HICs (78.8\%), LMICs (75.7\%), LICs (74.1\%) and UMICs (68.3\%). The ordering remains unchanged for stochastic methods. However, for deterministic models, higher MTE for HICs countries, followed by LICs, UMICs and LMICs.

Despite the large number of frontier models developed to improve measures of TE, there is no agreement as to the most appropriate methodology (Olesen et al., 1996). The studies of (Rivas, 2003; Moreira López, 2006; Bravo-Ureta et al., 2007; 
Moreira López \& Bravo-Ureta, 2009) examine the effects of methodology on reported TE measures.

In the study by Rivas (2003), a meta-regression analysis is performed to summarize and quantify the effects of methodological choices on the level of average dairy TE. To complement the narrative review, 36 published studies containing 105 estimates of mean TE were used to estimate a multiple regression model. MTE was regressed against a set of variables representing the methodological characteristics of the studies and other study specific characteristics, such as sample size, number of explanatory variables and the geographical location of the study. Rivas' (2003) results show that the level of TE is significantly higher for stochastic than for deterministic models. The observed differences in MTE between models with different functional forms were not statistically significant. The results from the metaregression analysis also reported that parametric models using cross-sectional data and large sample sizes yielded higher MTEs than those estimated using panel data and smaller sample sizes. Conversely, average TE in dairy farms did not vary by geographical location, number of variables in the model and year of data collection (Rivas, 2003).

Rivas (2003) argues that, although some controversial issues discussed in the literature have no answers on theoretical grounds (e.g., whether geographical location generates variation on MTE), the meta-regression analysis makes it possible to test the empirical evidence on efficiency estimation, given that the findings are based on more than one single study.

Moreira López (2006) updates and extends the work of Rivas (2003) and Bravo-Ureta et al. (2006) by performing a comprehensive search of published studies in English and Spanish. Their objectives were to examine both methodological effects on reported TE measures for dairy farms and the effect of econometric procedures on the meta-regressions. Thus, to examine both effects, Moreira López (2006) develops eight models, including different methodologies and study specific characteristics from 65 frontier studies totalling 329 observations. 
Moreira López (2006) results show that non-parametric deterministic models generate a MTE higher than the parametric ones (either stochastic or deterministic). The effect of functional form on TE is significant, and the Cobb-Douglas and translog forms yield MTEs higher than all other functions. Frontier models based on crosssectional data produce higher estimates than those based on panel data. Some geographical effects were also significant, such as a higher MTE for Asia and North America. Moreira López (2006) sought to integrate and systematize a wide range of TE estimates, focusing on the effects of both alternative methodological assumptions and alternative econometric procedures for the estimation of the meta-regression parameters. Part of the results presented in Moreira López (2006) is also presented in Moreira López and Bravo-Ureta (2009). Because the results in Moreira López and Bravo-Ureta (2009) are a sample of the broader results of Moreira López (2006), the paper will therefore refer to Moreira López (2006) results instead.

The main goal of the paper by Bravo-Ureta et al. (2007) was to examine the impact of various attributes of a study (e.g., estimation technique, functional form, sample size) on MTE estimates. A meta-regression analysis of 167 frontier studies of TE focusing on the agricultural sector was undertaken in developing and developed countries. Bravo-Ureta et al. (2007) extends the study by Thiam et al. (2001) that provided an analysis focusing on 34 papers covering only developing countries. The econometric results suggest that non-parametric deterministic models yield higher MTEs than stochastic frontier models, and that stochastic models in turn generate higher MTEs than non-parametric deterministic models. The effect of functional form on TE was inconclusive. In addition, frontier models based on cross-sectional data produced lower estimates than those based on panel data. The results for geographical regions are statistically significant, showing that countries located in Western Europe and Oceania presented MTE higher than other countries. Bravo-Ureta et al. (2007) revealed that MTEs are positively related to the average income of the countries in the dataset, but this pattern is broken by the upper middle-income group, which displayed the lowest MTE. The basic assumption of the present research is that the variation in MTE reported in the literature can be explained by a host of other factors. As reported by Olesen et al. (1996), the effect of estimation methods are still 
controversial, an issue confirmed by the results reported by Rivas (2003), Moreira López (2006), Bravo-Ureta et al. (2007) and Moreira López and Bravo-Ureta (2009). Based in the research propositions (column 1) developed from the meta-synthesis presented in Subsection 4.2 (first column of Table 8 and in the studies) that also examined the effects of factors in the TE level (second column of Table 8), the following hypothesis are put forward in the third column of Table 8.

Table 8: Propositions and hypothesis

\begin{tabular}{|c|c|c|}
\hline Research propositions & \begin{tabular}{|l|}
\multicolumn{1}{|c|}{ Extant literature } \\
\\
MTE indices reported \\
in the literature can be \\
explained by the \\
attributes of the \\
studies, including \\
estimation technique,
\end{tabular} & Hypothesis \\
\hline \multirow{2}{*}{$\begin{array}{l}\text { P5 - The levels of TE in dairy farms } \\
\text { vary according to the measurement } \\
\text { technique used. }\end{array}$} & \multirow{6}{*}{$\begin{array}{l}\text { MTE indices reported } \\
\text { in the literature can be } \\
\text { explained by the } \\
\text { attributes of the } \\
\text { studies, including } \\
\text { estimation technique, } \\
\text { functional form, type } \\
\text { of data, } \\
\text { dimensionality and } \\
\text { geographical region } \\
\text { for the region where } \\
\text { the farm data for the } \\
\text { study was collected } \\
\text { (Rivas, 2003; Moreira } \\
\text { López, 2006; Bravo- } \\
\text { Ureta et al., 2007) }\end{array}$} & 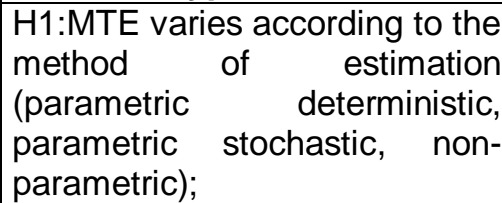 \\
\hline & & $\begin{array}{l}\text { H2:MTE varies according to the } \\
\text { functional form used (Coub- } \\
\text { Douglas, Translog, Others); }\end{array}$ \\
\hline - & & $\begin{array}{l}\text { H3:MTE varies according to the } \\
\text { data collection scheme (panel } \\
\text { versus cross-sectional data); }\end{array}$ \\
\hline $\begin{array}{l}\text { P6- The determinants of TE in } \\
\text { dairy farms varies according to the } \\
\text { number of variables included in the } \\
\text { models and the primary data } \\
\text { quality. }\end{array}$ & & $\begin{array}{l}\text { H4: MTE varies according to } \\
\text { the model dimensionality } \\
\text { (number of variables); }\end{array}$ \\
\hline \multirow{2}{*}{$\begin{array}{l}\text { P1- Dairy farms situated in } \\
\text { favourable geographical climate } \\
\text { and altitude, with good soil quality } \\
\text { and qualified human resources } \\
\text { have high TE. } \\
\text { P2-Dairy farms located in contexts } \\
\text { with public policies favouring } \\
\text { milking practices have high TE. }\end{array}$} & & $\begin{array}{l}\text { H5: MTE varies according to } \\
\text { the geographical location of the }\end{array}$ \\
\hline & & \\
\hline- & $\begin{array}{l}\text { MTE indices reported } \\
\text { in the literature can be } \\
\text { explained by the } \\
\text { income level (Bravo- } \\
\text { Ureta et al., 2007) } \\
\end{array}$ & $\begin{array}{l}\text { H6: MTE varies according to } \\
\text { the income level of the country; }\end{array}$ \\
\hline $\begin{array}{l}\text { P3 - Large dairy farms have higher } \\
\text { TE than smaller farms. }\end{array}$ & - & $\begin{array}{l}\text { H7: MTE varies according to } \\
\text { size (herd and land area). }\end{array}$ \\
\hline
\end{tabular}

To investigate these hypotheses formally, four models are estimated. The results of the statistical models are in the next subsection. In the following, results 
will be compared with the research propositions and with the three studies mentioned (Rivas, 2003; Moreira López, 2006; Bravo-Ureta et al., 2007), as seen in

Table 10 of the Result's Subsection. MTE was regressed against a set of variables representing the methodological characteristics (e.g., H1, H2, H3) of the studies and other study-specific characteristics (e.g., H4, H5, H6, H7).

\subsection{5}

Results of the statistical model

Table 9 depicts the econometric results for Models I, II, III and IV using the OLS and the two-limit Tobit approach. 
Table 9: Tobit meta-regressions of MTE in dairy farms

\begin{tabular}{|c|c|c|c|c|c|c|c|c|c|c|c|c|c|c|c|c|}
\hline \multirow{3}{*}{ Variable } & \multirow{2}{*}{\multicolumn{2}{|c|}{$\begin{array}{r}\text { Model I } \\
\text { OLS }\end{array}$}} & \multicolumn{6}{|c|}{ Model II } & \multicolumn{4}{|c|}{ Model III } & \multicolumn{4}{|c|}{ Model IV } \\
\hline & & & Tol & & OL & & Tob & & OL & & Tob & & OLS & & Tob & \\
\hline & Coef. & $p^{*}$ & Coef. & $\mathrm{p}^{*}$ & Coef. & $\mathrm{p}^{*}$ & Coef. & $p^{*}$ & Coef. & $p^{*}$ & Coef. & $p^{*}$ & Coef. & $p^{*}$ & Coef. & $p^{*}$ \\
\hline _CONS & 72.71 & 0.00 & 73.02 & 0.00 & 72.55 & 0.00 & 72.53 & 0.00 & 72.29 & 0.00 & 71.99 & 0.00 & 65.57 & 0.00 & 78.74 & 0.00 \\
\hline PSTO & 4.26 & 0.00 & 3.87 & 0.01 & 4.39 & 0.00 & 4.17 & 0.01 & 4.18 & 0.00 & 3.89 & 0.01 & 17.68 & 0.00 & 17.68 & 0.00 \\
\hline NP & 0.06 & 0.63 & 0.05 & 0.65 & 0.06 & 0.61 & 0.06 & 0.62 & 0.06 & 0.62 & 0.06 & 0.61 & -31.82 & 0.00 & -31.82 & 0.00 \\
\hline$C D$ & -2.71 & 0.12 & -2.71 & 0.14 & -3.03 & 0.10 & -3.19 & 0.09 & -2.29 & 0.22 & -2.60 & 0.18 & -7.22 & 0.04 & -7.22 & 0.03 \\
\hline OF & 4.76 & 0.00 & 5.14 & 0.00 & 4.46 & 0.01 & 4.53 & 0.01 & 4.63 & 0.01 & 4.57 & 0.01 & 46.47 & 0.00 & 46.47 & 0.00 \\
\hline CS & -4.49 & 0.74 & -0.87 & 0.57 & -0.28 & 0.86 & -0.55 & 0.73 & 0.65 & 0.67 & 0.47 & 0.77 & -0.80 & 0.82 & -0.80 & 0.81 \\
\hline VAR & 0.53 & 0.02 & 0.55 & 0.02 & 0.53 & 0.03 & 0.58 & 0.02 & 0.61 & 0.01 & 0.69 & 0.01 & 0.08 & 0.86 & 0.08 & 0.85 \\
\hline LIC & & & & & 0.31 & 0.86 & 1.79 & 0.33 & & & & & & & & \\
\hline LMIC & & & & & 0.73 & 0.74 & 0.74 & 0.75 & & & & & & & & \\
\hline UMIC & & & & & 1.61 & 0.38 & 1.40 & 0.46 & & & & & & & & \\
\hline ASIA & & & & & & & & & -0.13 & 0.94 & 1.52 & 0.40 & & & & \\
\hline NAMR & & & & & & & & & -2.19 & 0.20 & -1.93 & 0.28 & & & & \\
\hline AFRI & & & & & & & & & -36.55 & 0.01 & -37.08 & 0.01 & & & & \\
\hline LTCR & & & & & & & & & -0.76 & 0.70 & -0.69 & 0.73 & & & & \\
\hline EAST & & & & & & & & & 3.90 & 0.09 & 4.86 & 0.05 & & & & \\
\hline LAND & & & & & & & & & & & & & 0.00 & 0.76 & 0.00 & 0.74 \\
\hline cow & & & & & & & & & & & & & 0.03 & 0.04 & 0.03 & 0.03 \\
\hline$L^{* *}$ & & & -2.23 & & & & -2.23 & & & & -2.22 & & & & -319 & \\
\hline $\mathrm{N}$ & 531 & & 531 & & & & 531 & & & & 531 & & & & 95 & \\
\hline
\end{tabular}


Hypothesis 1 states that MTE varies according to the method of estimation (parametric deterministic, parametric stochastic, non-parametric). The coefficient for PSTO (parametric stochastic frontier) is positive and statistically significant $(\mathrm{p}<0.05)$ for all four models, yielding higher MTE than deterministic and nonparametric models. It confirms H1: MTE varies according to the method of estimation.

Hypothesis 2 (MTE varies according to the functional form used) is also confirmed. The regression coefficient for CD (Cobb-Douglas) is negative and statistically significant $(\mathrm{p}<0.1$ for Model II; $\mathrm{p}<0.05$ for Model IV). The coefficient for OF (other functional forms) is positive, with $\mathrm{p}<0.001$ for Models I and VI, $\mathrm{p}<0.05$ for Model II and III. This indicates that CD yields lower MTEs than TL forms and that OF produces higher MTE than CD and TL.

The coefficients for CS (cross-sectional) are not statistically significant and H3 ("MTE varies according to the data collection scheme, - panel versus cross-sectional data”) is not confirmed.

The effect of VAR is positive and statistically significant at $\mathrm{p}<0.05$ in Models I, II and III, confirming H4 ("MTE varies according to the model dimensionality”).

Hypothesis 5 is confirmed, based on the coefficients for the regional dummies included in Model III, meaning that on average, studies in Western Europe and Oceania (WEURO) are higher MTE than in other regions, but for Eastern Europe.

Hypothesis 6 analyses whether the income level of the country under study has an impact on MTE. Model II includes the country's average income level on the estimated MTE. The coefficients were not statistically significant. H6 is not confirmed.

Model IV introduces the variables COW and LAND to examine Hypothesis 7 (whether size measured by herd size and by the number of hectares produces variation in MTE). The effect of COW is positive and statistically significant at $\mathrm{p}<0.005$ ("MTE varies according to size (herd and land area)"). In contrast, the effect of average number of hectares per farm is not statistically significant. H7 is confirmed with size measured by the number of cows per farm. 
However, $\mathrm{H} 7$ is not confirmed when size is measured by the average number of hectares per farm. This result prompted the analysis of a variant of Model IV, introducing the ratio COW/LAND in the regression. The effect of COW/LAND is positive $(\mathrm{p}<0.01)$, showing that when measured by the efficient use of land per cow, MTE varies according to size (cow/hectare), further confirming H7.

The comparison of the results of this study with previous results from Rivas (2003), Moreira López (2006) e Bravo-Ureta et al. (2007) is summarized in Table 10. The first column presents the hypothesis tested, the second column the description of the hypothesis and the other columns indicate if the hypothesis was confirmed or not.

Table 10: Comparison of results

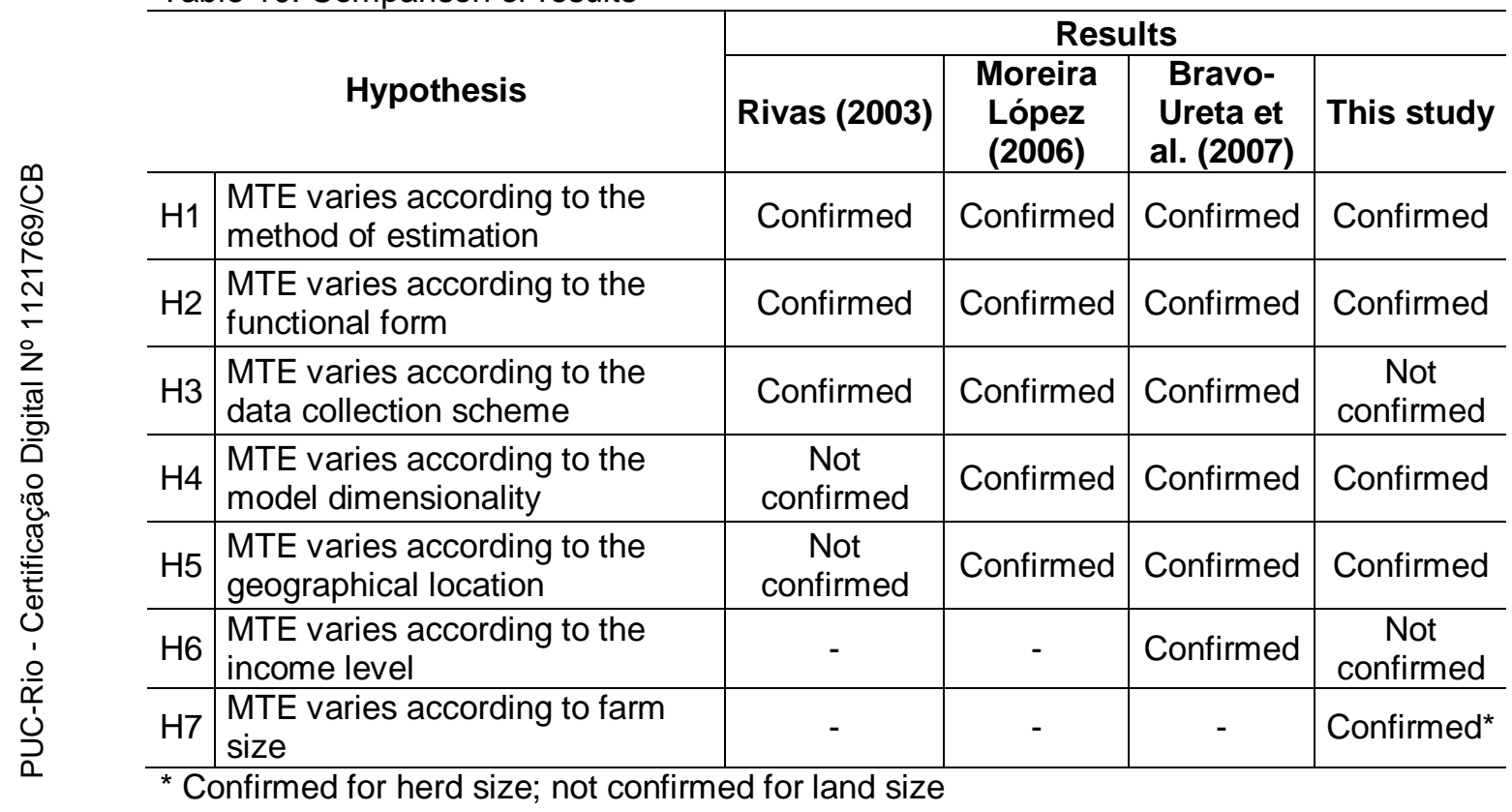

The confirmation of hypothesis are consistent among studies, the most notable exceptions being the variation of results according to the data collection scheme (H3: panel versus cross sectional data), not confirmed in our study but confirmed in all other previous studies. The results for CS suggest higher MTE estimates for cross sectional data than for models based on panel data in Rivas (2003). In contrast, Bravo-Ureta et al. (2007) show that CS yields lower MTE estimates than panel data. Moreira López (2006) met with mixed results, with higher MTE for cross sectional data in some meta-regression models and lower cross sectional MTE in other models. In all cases, despite the sense of the variation, results varied according to the data collection scheme utilized. 
However, Greene (1993) and Lovell (1996) indicate that parameter estimates from panel data would be more efficient in the use of the information, but there is no expectation regarding the effect of the type of data on TE, which would be consistent with results from this study that did not confirm H3.

For H1, the PSTO variable yields higher MTE than parametric deterministic models (PDTE) in the study of Rivas (2003) and in this study. Theoretically, a positive regression coefficient is expected for PSTO, given that deterministic models assume that all deviations from the frontier represented inefficiency (Coelli et al., 2005). However, both PSTO and PDTE present lower MTE than NP in the studies of Moreira López (2006) and Bravo-Ureta et al. (2007). The NP presents higher MTE in the four studies. Bravo-Ureta et al. (2007 p. 67) comment that "this result can be explained by the fact that Non-parametric deterministic studies typically yield numerous TE indexes equal to 100\% and such high measures increase the reported MTEs”.

The TL functional form presents higher MTE than CD in three studies: Rivas (2003), Bravo-Ureta et al. (2007) and this study. In the study of Rivas (2003) and in this study, other functional form yields higher MTE than both CD and TL. According to Bravo-Ureta et al. (2007), these results suggest that a more flexible functional form (TL) tends to yield a higher MTE. Additionally, Moreira López (2006) comments that "funcional form has an unclear effect on MTE", which is consistent with what was reported by Ahmad and Bravo-Ureta (1996), Resti (2000) and Thiam (2003).

The number of variables has a positive and significant effect on MTE measures in the study of Moreira López (2006) and in the present study. These results show an increase in MTE when the number of variables increases. The results on model dimensionality (VARSIZE) are not always statistically significant but in general, it indicate that the ratio used by Moreira López (2006) and Bravo-Ureta et al. (2007) to analyze this effect shows a positive association between MTE and model dimensionality (Chavas et al., 2005).

The effect of country's average income level on MTE was verified in Bravo-Ureta et al. (2007) but it was not consubstantiate in the present study. 
The four studies analysed whether location has an effect on MTE. ASIA and NAMR yield higher MTEs than WEURO in Moreira López (2006) and the same variables present lower MTEs than WEURO in Bravo-Ureta et al. (2007). AFRI and LATIN present lower MTEs than WEURO in Bravo-Ureta et al. (2007) and in the present study. EAST yields lower MTE than WEURO in Moreira López (2006) and Bravo-Ureta et al. (2007). Inversely, EAST produces higher than WEURO in the present study. In Rivas (2003), MTE in dairy farms did not vary based on geographical location; in Moreira López (2006), Bravo-Ureta et al. (2007) and in this research, the results for the regions were statistically significant. In Tauer and Belbase (1987) and Hansson (2007), the location also positively affected MTE.

Finally, the effect of cow and cow/hectare was positive and significant. However, the effect of size measured by the number of hectares was not significant. This result is conflicting with Haghiri et al. (2004, p. 1242), who report that, "no significant correlation was found between farm size (measured by number of milking cows) and the level of estimated TE”. Conversely, this finding is consistent with Tauer and Belbase (1987), Bravo-Ureta and Rieger (1991), Kompas and Che (2006) and Brümmer and Loy (2000), who found that the number of cows has a positive effect on TE. It is also consistent with Gelan and Muriithi (2010), who did not find that farm size (measured by acres) is statistically significant.

\subsection{6}

\section{Discussions}

This thesis complemented and extended previous literature reviews on TE in dairy farms by analysing the effects of different methodologies and studyspecific characteristics on mean TE. The MTE estimates reported in 531 distributions from 103 published papers were explained using meta-regression models that included methodological characteristics of the studies, geographical location, income, and farm size (herd and land size). The present study made two important contributions to the existing literature: (i) it updated and compared previous work on frontier estimation of TE in dairy farms and (ii) it added two 
dimensions of dairy farms: size (herd and land size) and economic development, to the known differentials of TE measurement.

Several issues analysed in the literature on efficiency were discussed and tested using a meta-regression model. The econometric results show that the level of TE is higher if the estimation is made from stochastic frontiers than from deterministic models. The coefficients for the Cobb-Douglas functional form were negative, indicating that CD yields lower MTEs than other functional forms. In addition, the parameter for cross-sectional data was inconclusive. The results show larger MTE when the number of variables included in the models is large. These findings might be of practical application in assisting to select the appropriate methods for measuring and modelling MTE.

Analysing the level of TE by geographical location, on average, studies in Western Europe and Oceania (WEURO) presented higher levels of MTE than other regions, but for Eastern Europe. Additional analysis by level of income per country was inconclusive in our research. The coefficient of variable SIZE, measured by the number of cows (herd) per farm is positive. The behaviour of size, using the proxy variable "cow per farm size" was also positive, further confirming the effect of farm size on MTE in dairy farms, novelty that shreds a new light in the literature. In conclusion, this study organized a wide range of empirical findings on TE in dairy farms and verified the effects of methodological characteristics (method of estimation, functional form of frontier models, model dimensionality), geographical location, and farm size on MTE indexes. No effects were found for the type of data collection (panel versus cross sectional data) and country’s income level.

Additionally, the results suggest that, given the state of technology prevailing in each country at the time that the studies on TE were conducted, dairy farmers in the sample could increase milk output by 20.1\% (level of inefficiency), on average, if they produce on their efficient frontiers. These results are similar to those of Bravo-Ureta et al. (2007), Moreira López (2006) and Rivas (2003), with $23.4 \%, 21.6 \%$ and $20 \%$, respectively. This study also contributes to the dairy literature due to the relevance of TE measures for both dairy farms management and policies formulation. A better understanding of TE measures and determinants could have a direct benefit on profitability once efficient dairy farms are expected 
to generate higher incomes, and thus have a better chance of surviving and staying in business.

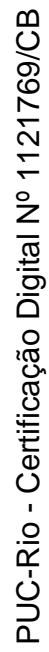




\section{5}

\section{Empirical study}

This Chapter offers the empirical study conducted in dairy farms from selected municipalities of the South of Brazil. The empirical results are presented in four subsections. The first subsection presents the distributions of the estimated efficiency score, using the VRS and CRS models. The second subsection presents benchmarking at the dairy farm level. Given the TE score of the VRS and CRS models, the third subsection presents the determinants of TE. Discussions are offered in the fourth subsection. The source of primary data for the DEA model and regression analysis (models V and VI) were presented in subsection 3.2.

\section{1}

\section{Estimated TE}

Table 11 shows the results from both orientation (input and output) and DEA models (CRS and VRS). For the CRS models (input and output orientation), the mean TE is $49.9 \%$ with standard deviation of $24.8 \%$. As previously discussed, although input and output orientations are conceptually different, the scores are the same if constant returns to scale are assumed (Hansson, 2007; Hansson \& Öhlmér, 2008). For VRS models, higher MTE is found for input-orientation (58.5\%), than for output-orientation (54.7\%). 
Table 11: Sample distribution of the estimated TE

\begin{tabular}{|c|c|c|c|c|c|c|c|c|}
\hline \multirow{2}{*}{ Item } & \multicolumn{4}{|c|}{ Input-orientation } & \multicolumn{4}{|c|}{ Output-orientation } \\
\hline & \multicolumn{2}{|c|}{ CRS } & \multicolumn{2}{|c|}{ VRS } & \multicolumn{2}{|c|}{ CRS } & \multicolumn{2}{|c|}{ VRS } \\
\hline Mean & \multicolumn{2}{|c|}{$49.9 \%$} & \multicolumn{2}{|c|}{$58.5 \%$} & \multicolumn{2}{|c|}{$49.9 \%$} & \multicolumn{2}{|c|}{$54.7 \%$} \\
\hline $\mathrm{SD}$ & \multicolumn{2}{|c|}{$24.8 \%$} & \multicolumn{2}{|c|}{$24.5 \%$} & \multicolumn{2}{|c|}{$24.8 \%$} & \multicolumn{2}{|c|}{$26.6 \%$} \\
\hline TE Interval & $\mathrm{n}$ & $\%$ & $\mathrm{n}$ & $\%$ & $\mathrm{n}$ & $\%$ & $\mathrm{n}$ & $\%$ \\
\hline 0.75 to 1 & 48 & $19.0 \%$ & 68 & $26.9 \%$ & 48 & $19.0 \%$ & 66 & $26.1 \%$ \\
\hline 0.50 to 0.74 & 42 & $16.6 \%$ & 62 & $24.5 \%$ & 42 & $16.6 \%$ & 40 & $15.8 \%$ \\
\hline 0.25 to 0.49 & 140 & $55.3 \%$ & 116 & $45.8 \%$ & 140 & $55.3 \%$ & 130 & $51.4 \%$ \\
\hline 0 to 0.24 & 23 & $9.1 \%$ & 7 & $2.8 \%$ & 23 & $9.1 \%$ & 17 & $6.7 \%$ \\
\hline
\end{tabular}

Regarding the distribution of MTE for CRS and VRS models, results show that approximately $19 \%$ and $26 \%$ of the dairy farms achieved TE levels of 0.75 or higher. On the other hand, most of the dairy farms (55.3\%, 45.8\% and 51.4\%) achieved TE levels comprised between 0.25 and 0.49 .

By applying data envelopment analysis (DEA) in 253 selected dairy farms, it is found that 27 (CRS model) and 44 (VRS model) are on the efficient frontier. Farms with a technical CRS and VRS score of 1 were considered efficient (on the data envelopment analysis frontier), whereas those with a technical CRS and VRS score below 1 were considered less efficient. Figure 10 shows the distribution of technical efficiency scores for both models.

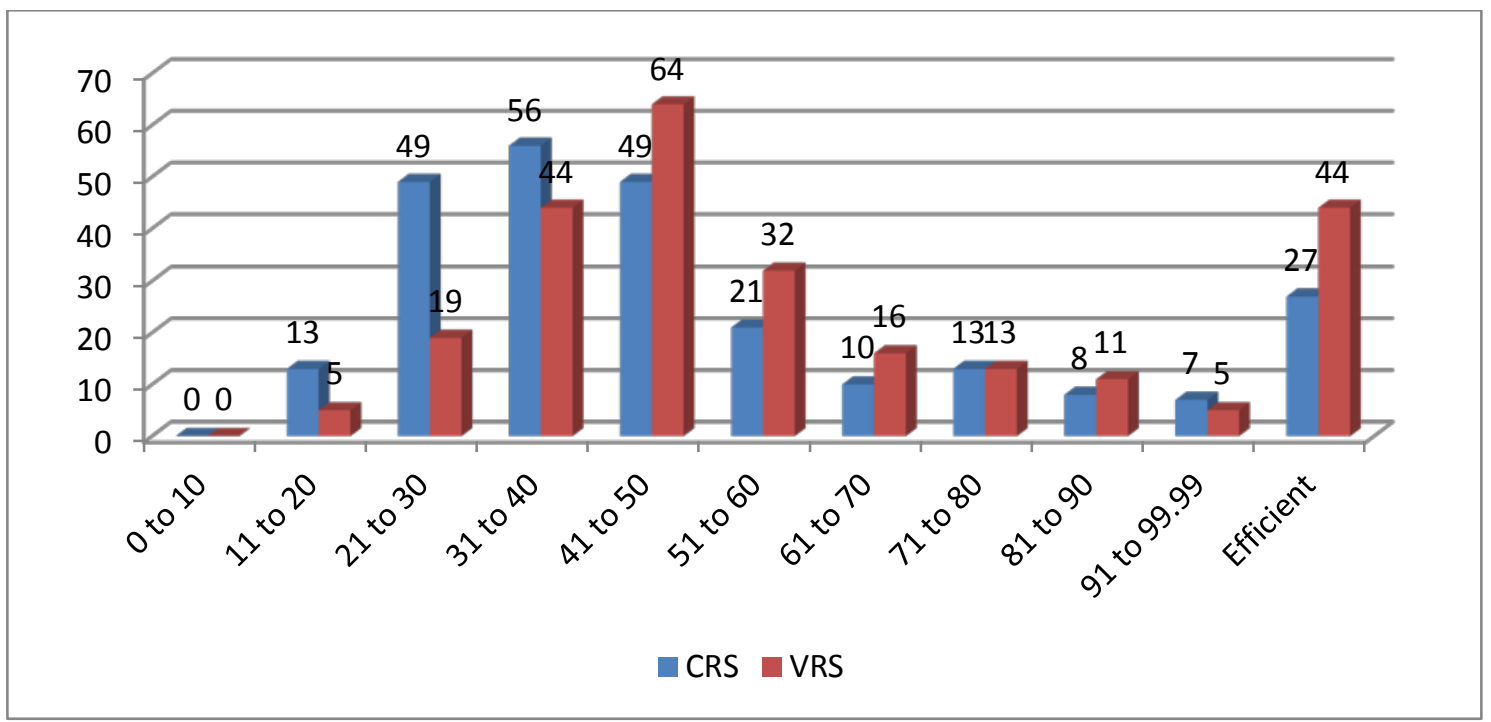

Figure 10: Sample distribution of the TE of the CRS and VRS model (input-orientation)

The technically efficient farmers presented in Figure 10 ( $n=27$ for CRS, $\mathrm{n}=44$ for VRS) are compared with less technical efficient farmers ( $\mathrm{n}=226$ for 
CRS, n=209 for VRS). Table 12 showed great heterogeneity between sample producers, since all variables have large coefficient of variation (CV). The variables with higher variability are: feed costs (234\% for efficient farms, 263\% and $278 \%$ for less efficient farms) and acres of land (206\% for efficient farms, $214 \%$ for less efficient farms). This wide variation is similar to the one found in the study of Nascimento et al. (2012).

Table 12: Comparison of technically efficient and less technical efficient farmers

\begin{tabular}{|c|c|c|c|c|c|c|c|c|c|c|c|c|}
\hline \multirow{3}{*}{ Item } & \multicolumn{6}{|c|}{ CRS model } & \multicolumn{6}{|c|}{ VRS model } \\
\hline & \multicolumn{3}{|c|}{ Efficient farms $(n=27)$} & \multicolumn{3}{|c|}{$\begin{array}{l}\text { Less efficient farms } \\
\qquad(n=226)\end{array}$} & \multicolumn{3}{|c|}{ Efficient farms $(n=44)$} & \multicolumn{3}{|c|}{$\begin{array}{l}\text { Less efficient farms } \\
\qquad(n=209)\end{array}$} \\
\hline & Mean & SD & $\begin{array}{l}\text { CV } \\
(\%)\end{array}$ & Mean & SD & $\begin{array}{l}\text { CV } \\
(\%)\end{array}$ & Mean & SD & $\begin{array}{l}\text { CV } \\
(\%)\end{array}$ & Mean & SD & $\begin{array}{l}\text { CV } \\
(\%)\end{array}$ \\
\hline Feed & 30355 & 70932 & 234 & 24025 & 63088 & 263 & 31748 & 60382 & 190 & 23217 & 64595 & 278 \\
\hline Labour & 3228 & 3908 & 121 & 6213 & 8284 & 133 & 4564 & 8793 & 193 & 6174 & 7793 & 126 \\
\hline Cow & 52 & 58 & 111 & 40 & 38 & 95 & 61 & 66 & 108 & 38 & 32 & 86 \\
\hline Land & 69 & 71 & 103 & 65 & 139 & 214 & 106 & 219 & 206 & 56 & 105 & 186 \\
\hline Milk & 294681 & 321318 & 109 & 158228 & 187124 & 118 & 331495 & 359165 & 108 & 139378 & 140798 & 101 \\
\hline
\end{tabular}

Table 12 showed that efficient farms (considered here as farms on the CRS technical frontier) in the sample had higher milk production, a greater number of cows and acres of land, and a higher level of feed costs than inefficient farms. Inefficient farms in the sample had higher level of labour costs. Only 9 farms (for CRS models) and 10 farms (for VRS models) of the efficient farms received bonus by quality and quantity of milk produced. The group of technically less efficient farms (CRS and VRS specification) consisted of 226 and 209 cases; the technical inefficiency scores of those farms were on average $43.8 \%$ and $49.7 \%$, with a standard deviation of $19 \%$ and $17.4 \%$.

These observations are evidences that large farms are more technically efficient than smaller counterparts. A reason may be that bigger farms have greater feed costs, invest more in technology and animal health. An explication in relation to labour costs may be that the small and middle sized farms need complement the family income with off-farm work. This situation increases the labour costs, because in order to meet the demands of activity the farmers need to hire workers. The quantification of TE for DMUs from the DEA is not enough to 
guide the producer in order to improve the degree of efficiency. It needs to identify how much of this inefficiency could be improved when eliminating the excesses in the use of inputs (Ferreira \& Gomes, 2009). Some suggestions to improve (subsection 5.2 Benchmarks) and explain (subsection 5.3 Determinants) the TE level of the group of technically inefficient farms are described in the next two subsections.

This TE level is similar to the one found in the study of Sousa et al. (2012) (54.5\%), that was realized in the Brazilian State of Goiás. Goiás State (10.9\%) is considered the fourth national producer, surpassed by Minas Gerais (27.3\%), Rio Grande do Sul (12.1\%) and Paraná (11.9\%) in 2011 (IBGE, 2011). Despite of TE's somehow similar levels, the variation in average efficiency between the two studies reflects the reality of different Brazilian regions, different time periods (2009 versus 2010), differences in input and output selections, and differences in sample size (500 versus 253 farms). Sousa et al. (2012) used two outputs (sale of milk produced and sale of animals) and this study used milk (measured in litters) and bonus. Other differences are that Sousa et al. (2012) include machinery and installations, and this study includes feed as an input. Finally, the two studies used land, labour and cow as inputs.

Higher MTE were presented in four other studies developed in Brazil, in the State of Minas Gerais (first national producer): 88.8\% (Santos et al., 2004), 88.2\% (Santos et al., 2005), 78.1\% (Gonçalves et al., 2008) and 83.0\% (Nascimento et al., 2012). The variation in MTE among the four studies (Santos et al., 2004; Santos et al., 2005; Gonçalves et al., 2008 and Nascimento et al., 2012) also reflects different time periods (1999-2002, 1999-2003, 2005 and 2005), differences in input and output selections, and differences in sample size $(28,17$, 771 and 875 farms). These differences in results notwithstanding, the estimates are based on samples measured at different time periods and with minor differences in inputs and outputs. There is a strong consensus that Minas Gerais (MG) dairy farm efficiency is high (Santos et al., 2004; Santos et al., 2005; Gonçalves et al., 2008 and Nascimento et al., 2012). Serviço Brasileiro de Apoio às Micro e Pequenas Empresas de Minas Gerais (SEBRAE-MG) and Federação da Agricultura e Pecuária de Minas Gerais (FAEMG) did a diagnostic of dairy farms in 2005 in this State (FAEMG, 2006). In addition, the farms receive 
technical assistance from a program created by the Federal University of Viçosa and Nestlé.

Gonçalves et al. (2008) and Nascimento et al. (2012), based on the same data (the 2005 diagnostic of dairy farms), identified the determining factors of their TE, using, respectively, econometric Tobit model and quantile regression. Gonçalves et al. (2008) used three production level categories, according to FAEMG (2006): less than $50 \mathrm{~L}$ milk/day; from 50 to $200 \mathrm{~L}$ milk/day; and above 200 L milk/day. Nascimento et al. (2012) estimated quantile regressions for different TE level (5th quantile - less efficient, 50th quantile, quantile 90 - more efficient), trying to verify how the different producers are influenced in relation to the characteristics of the management of rural property.

In the study of Nascimento et al. (2012), the percentage of dairy cows and unit gross margin variables were significant in explaining the differences in efficiencies in all quantiles. The family labour percentage was significant in the $5^{\text {th }}$ and $50^{\text {th }}$ quantile. In Gonçalves et al. (2008), labour productivity and productivity of operating capital were significant in all categories, explaining the different TE levels. In relation to the labour variable, Gonçalves et al. (2008, p. 331) conclude that labour productivity (measured by the total revenue/labour costs ratio) contributed positively to technical efficiency, independently of the production level. "Clearly, the impact of labour productivity on technical efficiency is higher for producers from lower production levels, which reflects the importance of labour for these groups” (Nascimento et al., 2012, p. 788), analysed the percentage of family labour. "Those producers who employ most hand-family labour percentage are also those with lower technical efficiency" (Nascimento et al., 2012, p. 788).

The technical visits variable in the study of Nascimento et al. (2012) was non-significant in the three quantiles studied. In Gonçalves et al. (2008), the same variable of technical visit was significant for farms of higher production levels (50 to 200 litters/day and above 200 litters/day). "Thus, for these two production levels, the presence of the technician was important in explaining the level of technical efficiency, having greater impact at higher production levels” (Gonçalves et al., 2008, p. 332). 
Despite of all these studies in dairy farms developed in Brazil, the variation of TE levels reflects different regions, different time periods, differences in sample size, different measurement techniques, and differences in input and output variables. The next subsections presents the benchmarks and determinants of TE of the empirical study and compares these results with the results of others studies.

\section{2}

\section{Benchmarks}

The measure of TE is specific to the sample of 253 dairy farms. The 27 DMUs 100\% efficient (first, second and third columns), in the CRS models, are presented in the Table 13. These 27 DMUs form a best practice frontier and are benchmark peers for inefficient DMUs. The fourth and fifth columns showed the frequency (number of times and percents) that each efficient DMU was reference for inefficient DMUs. For example, Farm Q10 ( $\mathrm{N}^{\mathrm{o}}$ 1) was benchmark peer for 181 (22.4\%) inefficient DMUs. 
Table 13: Reference set frequency

\begin{tabular}{|c|c|c|c|c|c|c|c|c|c|}
\hline \multirow{3}{*}{$\mathbf{N}$} & \multirow{2}{*}{$\begin{array}{c}\text { Efficien } \\
t \\
\text { DMUs }\end{array}$} & \multirow{2}{*}{\multicolumn{2}{|c|}{ TE level $\begin{array}{c}\text { Referenc } \\
\text { e set } \\
\text { frequenc } \\
y\end{array}$}} & \multirow[b]{2}{*}{$\%$} & \multicolumn{3}{|c|}{ Efficien } & \multirow{2}{*}{$\begin{array}{c}\text { Referenc } \\
\text { e set } \\
\text { frequenc } \\
y \\
\end{array}$} & \multirow[b]{2}{*}{$\%$} \\
\hline & & & & & $\mathbf{N}$ & $\begin{array}{c}\mathbf{t} \\
\text { DMUs }\end{array}$ & TE level & & \\
\hline & & 100.00 & & 22.4 & 1 & & 100.00 & & \\
\hline \multirow[t]{2}{*}{1} & Q10 & $\%$ & 181 & $\%$ & 5 & N27 & $\%$ & 6 & $0.7 \%$ \\
\hline & & 100.00 & & 20.8 & 1 & & 100.00 & & \\
\hline \multirow[t]{2}{*}{2} & Q28 & $\%$ & 168 & $\%$ & 6 & S16 & $\%$ & 5 & $0.6 \%$ \\
\hline & & 100.00 & & 15.2 & 1 & & 100.00 & & \\
\hline \multirow[t]{2}{*}{3} & 142 & $\%$ & 123 & $\%$ & 7 & C14 & $\%$ & 5 & $0.6 \%$ \\
\hline & & 100.00 & & & 1 & & 100.00 & & \\
\hline \multirow[t]{2}{*}{4} & $\mathrm{C} 27$ & $\%$ & 48 & $5.9 \%$ & 8 & N23 & $\%$ & 4 & $0.5 \%$ \\
\hline & & 100.00 & & & 1 & & 100.00 & & \\
\hline \multirow[t]{2}{*}{5} & BVI17 & $\%$ & 48 & $5.9 \%$ & 9 & F6 & $\%$ & 4 & $0.5 \%$ \\
\hline & & 100.00 & & & 2 & & 100.00 & & \\
\hline \multirow[t]{2}{*}{6} & C17 & $\%$ & 46 & $5.7 \%$ & 0 & T16 & $\%$ & 3 & $0.4 \%$ \\
\hline & & 100.00 & & & 2 & & 100.00 & & \\
\hline \multirow[t]{2}{*}{7} & C31 & $\%$ & 39 & $4.8 \%$ & 1 & F11 & $\%$ & 3 & $0.4 \%$ \\
\hline & & 100.00 & & & 2 & & 100.00 & & \\
\hline \multirow[t]{2}{*}{8} & L5 & $\%$ & 26 & $3.2 \%$ & 2 & F9 & $\%$ & 2 & $0.2 \%$ \\
\hline & & 100.00 & & & 2 & & 100.00 & & \\
\hline 9 & F19 & $\%$ & 24 & $3.0 \%$ & 3 & F5 & $\%$ & 2 & $0.2 \%$ \\
\hline 1 & & 100.00 & & & 2 & & 100.00 & & \\
\hline 0 & L10 & $\%$ & 17 & $2.1 \%$ & 4 & F3 & $\%$ & 2 & $0.2 \%$ \\
\hline 1 & & 100.00 & & & 2 & & 100.00 & & \\
\hline 1 & N31 & $\%$ & 13 & $1.6 \%$ & 5 & BVI2 & $\%$ & 2 & $0.2 \%$ \\
\hline 1 & & 100.00 & & & 2 & & 100.00 & & \\
\hline 2 & L8 & $\%$ & 13 & $1.6 \%$ & 6 & F7 & $\%$ & 1 & $0.1 \%$ \\
\hline 1 & & 100.00 & & & 2 & & 100.00 & & \\
\hline 3 & BVl8 & $\%$ & 12 & $1.5 \%$ & 7 & F17 & $\%$ & 1 & $0.1 \%$ \\
\hline 1 & & 100.00 & & & & & & & 100 \\
\hline 4 & BVI7 & $\%$ & 10 & $1.2 \%$ & & Tot & & 808 & $\%$ \\
\hline
\end{tabular}

Each efficient DMUs or a combination of both efficient DMUs can be reference for inefficient DMUs. In Table 14 (line 1), for example, efficient DMUs C31, L10 and N27 are benchmarks for inefficient DMU L6. The benchmark farms are those that have a similar production mix. Others random examples of inefficient DMUs and their potential improvements are shown in the Table 14 . Inefficient DMUs presents in the Column 1, TE level in the Column 2, inputs (cow, feed, labour and land) and outputs variables (milk and bonus) in the next columns, followed by benchmarks units and models. 
Table 14: Potential improvement (\%) for inefficient DMUs

\begin{tabular}{|c|c|c|c|c|c|c|c|c|c|c|c|}
\hline \multirow{2}{*}{$\begin{array}{l}\text { Inefficient } \\
\text { DMUs }\end{array}$} & \multirow{2}{*}{ TE } & \multicolumn{4}{|c|}{ Inputs } & \multicolumn{2}{|c|}{ Outputs } & \multirow{2}{*}{\multicolumn{3}{|c|}{$\begin{array}{c}\text { Benchmarks } \\
\text { (Efficient DMUs) }\end{array}$}} & \multirow{2}{*}{$\begin{array}{c}\text { Models- } \\
\text { orientation }\end{array}$} \\
\hline & & Cow & Feed & Labour & Land & Milk & Bonus & & & & \\
\hline L6 & $98.47 \%$ & -28.8 & -1.5 & -1.5 & -1.5 & & 112.7 & C31 & L10 & N27 & CRS-I \\
\hline N24 & $92.14 \%$ & -7.9 & -51 & -7.9 & -90.1 & - & - & 142 & Q10 & Q28 & CRS-I \\
\hline 162 & $9.72 \%$ & -49 & -54.2 & -56.7 & -10.3 & - & - & 142 & Q10 & & CRS-I \\
\hline BVI18 & $5.37 \%$ & -58.1 & -14.6 & -56.8 & -14.6 & - & - & BVI8 & C31 & Q10 & CRS-I \\
\hline Q13 & $97 \%$ & -22 & -48 & -22 & -26.5 & - & - & 142 & Q10 & Q28 & CRS-I \\
\hline Q8 & . & -24.1 & -29.6 & -24.1 & -56.6 & - & - & $\mathrm{C} 27$ & Q10 & Q28 & CRS-I \\
\hline T3 & 73\% & -28.3 & -40.2 & -28.3 & -29.9 & - & 85 & $\mathrm{C} 27$ & Q28 & & CRS-I \\
\hline CA19 & $43.08 \%$ & -56.9 & -57.5 & -56.9 & -56.9 & 49.1 & - & BVC7 & I17 & 146 & VRS-I \\
\hline
\end{tabular}

The input with negative percentage means that the improvement in TE level will occur from the reduction of their use in milk production. The maximization is expected to output. The output 'milk production' indicates the percentage that will maximize production, if the goals of inputs are met. For example DMU CA19, milk production will increase in 49.1\% (Outputs: milk), if occurs a reduction of $56.9 \%, 57.5 \%, 56.9 \%$ and $56.9 \%$ to cow, feed, labour and land variables (Inputs), respectively. The DMU CA19 (43.08\% efficient) has three farms with similar production mix (benchmark): BVC7, I17 and I46.

Farm T3 (71.7\% efficient) is other example with two benchmark farms: C27 and Q28.

Table 15 show a proportion of benchmark farms used to construct targets (\% change - column 8). Farm T3 Actual data (inputs and output variables) are provided in columns 2, 3 and 4. Columns 5 and 6 present a proportion of benchmark farms (86.83\% for Farm C27 and 98.16\% for Farm Q28) used to construct targets for Farm T3 (column 7).

Table 15: DEA results for Farm T3 under CRS model

\begin{tabular}{|c|c|c|c|c|c|c|c|}
\hline \multirow{3}{*}{$\begin{array}{l}\text { Inputs } \\
\text { and } \\
\text { output }\end{array}$} & \multirow{2}{*}{$\begin{array}{l}\text { Efficiency } \\
71.7 \% \\
\text { Farm T3 }\end{array}$} & \multicolumn{2}{|c|}{$\begin{array}{c}\text { Benchmarks } \\
\text { (100\% efficients) }\end{array}$} & \multicolumn{2}{|c|}{$\begin{array}{c}\text { Proportion of } \\
\text { benchmark farms used } \\
\text { to construct targets for } \\
\text { Farm T3 } \\
\end{array}$} & \multirow{3}{*}{$\begin{array}{c}\text { Target } \\
\text { for Farm } \\
\text { T3 }\end{array}$} & \multirow[t]{3}{*}{$\begin{array}{c}\% \\
\text { change }\end{array}$} \\
\hline & & Farm C27 & Farm Q28 & Farm C27 & Farm Q28 & & \\
\hline & & Actual data & & $86.83 \%$ & $98.16 \%$ & & \\
\hline Cow & 78 & 26 & 34 & 23 & 32 & 55 & -28.3 \\
\hline Feed & 43200 & 19020 & 9500 & 16515 & 9325 & 25840 & -40.2 \\
\hline Labour & 6000 & 1000 & 3500 & 868 & 3435 & 4304 & -28.3 \\
\hline Land & 62 & 32 & 16 & 28 & 16 & 43 & -29.9 \\
\hline Milk & 511000 & 212000 & 333062 & 184080 & 326920 & 511000 & - \\
\hline
\end{tabular}


The benchmark's farms are therefore highly appropriate for the inefficient farm to learn from. As depicted in Table 15, to be fully efficient, it needs to adopt best practices from these benchmark farms and to reduce in $28.3 \%$ the number of cows, in $40.2 \%$ the feed costs, in $28.3 \%$ the labour costs and, in $29.9 \%$ the acres of land for that level of milk production.

In addition to measuring the efficiency, DEA provides a guide for producers to eliminate inefficiencies.

Table 15 showed that the inefficient producers may have as a reference peer benchmarks and try to increase efficiency in production. Figure 11 shows the total potential improvements of efficiency from the reduction of inputs and the increase in products, in percentage terms, to the inefficiency group of dairy farms.

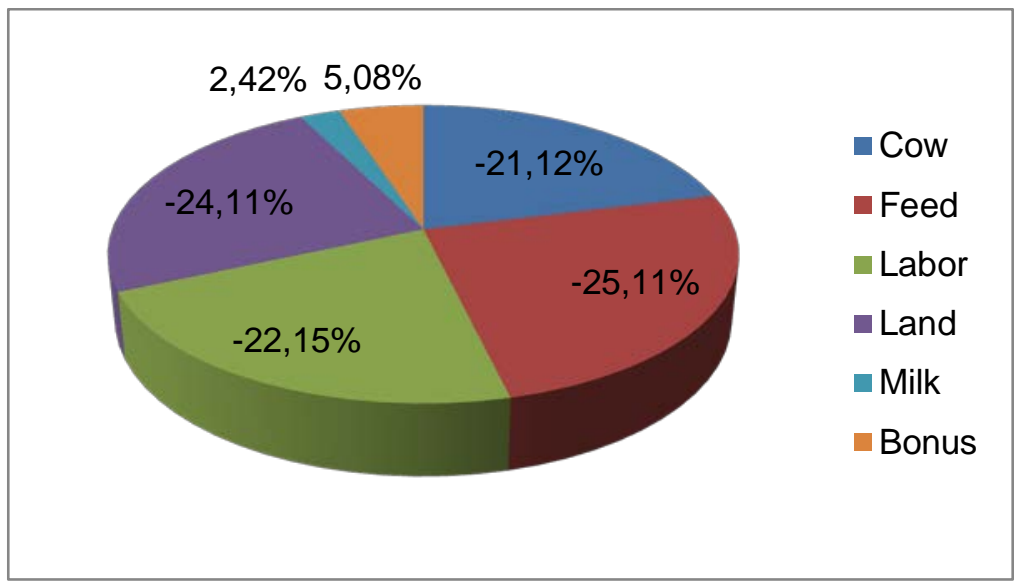

Figure 11: Total potential improvements

The feed costs presents the major percentage $(-25.11 \%)$ of potential improvement to dairy farms, followed by land (-24.11\%), labour $(-22.15 \%)$ and cow $(-21.12 \%)$. These reductions in the inputs result in the increase of the outputs: milk production (2.42\%) and bonus (5.08\%). The next subsection presents more analysis on these six variables from the analysis of determinants of TE. Others variables also was included in the regression model to explain the factors that affect TE level. 


\section{Determinants of TE}

This subsection presents the determinants of TE based on the empirical study. The results are presented in 2 subsections. The first subsection offers the propositions and hypotheses that will be tested. The second subsection presents the determinants of TE and compares the results of the empirical study with others studies.

\section{3 .1}

\section{Propositions and hypotheses}

Several authors dealing with the subject in the literature (49 papers in total) have discussed the determinants of TE because understanding these factors can improve efficiency and performance of dairy farms. Their studies analysed the effects of different methodologies and study-specific characteristics on Mean TE (MTE).

Table 16 presents the propositions (Column 1) and hypothesis (Column 2) elaborated from the previous studies (Column 3) that will be tested in the empirical study offered in the next chapter of this Thesis. 
Table 16: Propositions and hypothesis

\begin{tabular}{|c|c|c|}
\hline Propositions & $\begin{array}{l}\text { Hypothesis for } \\
\text { empirical study }\end{array}$ & Authors \\
\hline $\begin{array}{l}\text { P1: Dairy farms } \\
\text { situated in } \\
\text { favourable } \\
\text { geographical } \\
\text { climate and } \\
\text { altitude, with } \\
\text { good soil } \\
\text { quality and } \\
\text { qualified } \\
\text { human } \\
\text { resources have } \\
\text { high TE }\end{array}$ & $\begin{array}{l}\text { H1a: MTE varies } \\
\text { according to the } \\
\text { education of the } \\
\text { farm operator }\end{array}$ & $\begin{array}{l}\text { Tauer and Belbase (1987), Kumbhakar et al. (1991), } \\
\text { Bravo-Ureta and Rieger (1991), Tauer (1993), } \\
\text { Hallam and Machado (1996), Heshmati (1998), } \\
\text { Alvarez and González (1999), Rivas (2003), Haghiri } \\
\text { et al. (2004), Latruffe et al. (2004, 2005), Moreira } \\
\text { López (2006), Bravo-Ureta et al. (2007), Hansson } \\
\text { (2007), D'Haese et al. (2009), Gelan and Muriithi } \\
\text { (2010), Rouse et al. (2010), Del Corral et al. (2011), } \\
\text { Chang and Mishra (2011), Ma et al. (2012), Areal et } \\
\text { al. (2012), Bardhan and Sharma (2013), Sauer and } \\
\text { Latacz-Lohmann (2013), Dong et al. (2013), } \\
\text { Minegishi (2013), Shortall and Barnes (2013) }\end{array}$ \\
\hline $\begin{array}{l}\text { P3: Large dairy } \\
\text { farms have } \\
\text { higher TE than } \\
\text { smaller farms }\end{array}$ & $\begin{array}{l}\text { H2a: MTE varies } \\
\text { according to farm } \\
\text { size (number of } \\
\text { cows, land and } \\
\text { milk) }\end{array}$ & $\begin{array}{l}\text { Tauer and Belbase (1987), Bravo-Ureta and Rieger } \\
\text { (1990, 1991), Kumbhakar et al. (1989, 1991), Tauer } \\
\text { (1993), Ahmad and Bravo-Ureta (1996), Hallam and } \\
\text { Machado (1996), Heshmati (1998), Alvarez and } \\
\text { González (1999), Brümmer and Loy (2000), Maietta } \\
\text { (2000), Alvarez and Arias (2004), Latruffe et al. } \\
\text { (2004, 2005), Iráizoz et al. (2005), Johansson } \\
\text { (2005), Kompas and Chu (2006), Hadley (2001, } \\
\text { 2006), Hansson (2007), Barnes (2008), Rouse et al. } \\
\text { (2010), Gelan and Muriithi (2010), Del Corral et al. } \\
\text { (2011), Areal et al. (2012), Ma et al. (2012), Bardhan } \\
\text { and Sharma (2013), Shortall and Barnes (2013), } \\
\text { Dong et al. (2013), Ang and Oude Lansink (2014), } \\
\text { Jiang and Sharp (2014), Luik et al. (2014), Skevas et } \\
\text { al. (2014), Van der Voort et al. (2014) } \\
\end{array}$ \\
\hline \multirow{3}{*}{$\begin{array}{l}\text { P4: Care with } \\
\text { animal health, } \\
\text { feeding } \\
\text { practices, } \\
\text { milking } \\
\text { systems, direct } \\
\text { investments } \\
\text { and use of } \\
\text { agricultural } \\
\text { services } \\
\text { mediate or } \\
\text { moderate the } \\
\text { effect of farm } \\
\text { size on TE }\end{array}$} & $\begin{array}{l}\text { H3a: MTE varies } \\
\text { according to } \\
\text { milking systems }\end{array}$ & $\begin{array}{l}\text { Tauer and Belbase (1987), Bravo-Ureta and Rieger } \\
\text { (1990, 1991), Tauer (1993), Ahmad and Bravo-Ureta } \\
\text { (1996), Hallam and Machado (1996), Alvarez and } \\
\text { González (1999), Latruffe et al. (2004, 2005), } \\
\text { Iráizoz et al. (2005), Kompas and Chu (2006), } \\
\text { Hansson (2007), Hansson and Öhlmér (2008), } \\
\text { Cabrera et al (2010), Chidmi et al. (2010), Gelan and } \\
\text { Muriithi (2010), Rouse et al. (2010), Barnes et al. } \\
\text { (2011), Del Corral et al. (2011), Chang and Mishra } \\
\text { (2011), Ma et al. (2012), Michaličková et al. (2013), } \\
\text { Dong et al. (2013), Sauer and Latacz-Lohmann } \\
\text { (2013), Luik et al. (2014), Skevas et al. (2014), Van } \\
\text { der Voort et al. (2014), Uddin et al. (2014) }\end{array}$ \\
\hline & $\begin{array}{l}\text { H4a: MTE varies } \\
\text { according to feed }\end{array}$ & $\begin{array}{l}\text { Ahmad and Bravo-Ureta (1996), Hallam and } \\
\text { Machado (1996), Kompas and Chu (2006), Cabrera } \\
\text { et al (2010), Chidmi et al. (2010), Gelan and Muriithi } \\
\text { (2010), Del Corral et al. (2011), Michaličková et al. } \\
\text { (2013), Dong et al. (2013) }\end{array}$ \\
\hline & $\begin{array}{l}\text { H5a: MTE varies } \\
\text { according to } \\
\text { labour }\end{array}$ & $\begin{array}{l}\text { Ahmad and Bravo-Ureta (1996), Hallam and } \\
\text { Machado (1996), Latruffe et al. (2004), Iráizoz et al. } \\
\text { (2005), Chidmi et al. (2010), Cabrera et al (2010), } \\
\text { Del Corral et al. (2011), Michaličková et al. (2013) }\end{array}$ \\
\hline \multirow{2}{*}{$\begin{array}{l}\text { P7: The levels } \\
\text { of TE in dairy } \\
\text { farms vary } \\
\text { according to } \\
\text { the } \\
\text { management }\end{array}$} & $\begin{array}{l}\text { H6a: MTE varies } \\
\text { according to use } \\
\text { of insemination }\end{array}$ & Alvarez and González (1999) \\
\hline & $\begin{array}{l}\text { H7a: MTE varies } \\
\text { according to } \\
\text { breed }\end{array}$ & $\begin{array}{l}\text { Hansson and Öhlmér (2008), Gelan and Muriithi } \\
(2010)\end{array}$ \\
\hline
\end{tabular}




\begin{tabular}{c|c|l}
\hline Propositions & $\begin{array}{c}\text { Hypothesis for } \\
\text { empirical study }\end{array}$ & \multicolumn{1}{c}{ Authors } \\
\hline $\begin{array}{c}\text { practices } \\
\text { adopted }\end{array}$ & $\begin{array}{c}\text { H8a: MTE varies } \\
\text { according to use } \\
\text { of services }\end{array}$ & $\begin{array}{l}\text { Bravo-Ureta and Rieger (1991), Gonçalves et al. } \\
(2008), \text { Nascimento et al. (2012), Chang and Mishra } \\
(2011), \text { Dong et al. (2013), Michaličková et al. } \\
(2013), \text { Uddin et al. (2014) }\end{array}$ \\
\hline
\end{tabular}

The eight hypothesis of Table 14 will be tested in the empirical study. The hypotheses H1a (MTE varies according to the education of the farm operator) will test partially P1 (dairy farms situated in favourable geographical climate and altitude, with good soil quality and qualified human resources have high TE), as it refers to qualified human resources alone. The Hypotheses H3a (MTE varies according to milking systems), H4a (MTE varies according to feed) and H5a (MTE varies according to labour) not test P4 (Care with animal health, feeding practices, milking systems, direct investments and use of agricultural services mediate or moderate the effect of farm size on TE). P4 refers to the moderator or mediator effect and these hypotheses test the direct effect.

The results and comparison of the results with others studies are in the next subsection.

\subsection{2 \\ Determinants}

Table 17 depicts the econometric results for Models V and VI using the OLS and two-limit Tobit approach. In order to identify the causes of inefficiency, the determinants have been computed through DEA CRS model using outputorientation.

Hypothesis 1a states that MTE varies according to the education of the farm's operators (EDU2 is a dummy variable indicating that the farmer finished high school and EDU3 is a dummy variable indicating that the farmer has higher education). The coefficient for EDU3 is positive and statistically significant $(\mathrm{p}<0.05)$ for Model VI (OLS and Tobit), yielding higher MTE to farmer with higher education. It confirms H1a: MTE varies according to the education of the farm's operators. 
Table 17: OLS and Tobit regression of TE in dairy farms

\begin{tabular}{|c|c|c|c|c|c|c|c|c|c|}
\hline \multirow{3}{*}{ Variables } & \multirow{3}{*}{$\begin{array}{l}\text { Predict } \\
\text { sign }\end{array}$} & \multicolumn{4}{|c|}{ Model V } & \multicolumn{4}{|c|}{ Model VI } \\
\hline & & \multicolumn{2}{|c|}{ OLS } & \multicolumn{2}{|c|}{ Tobit } & \multicolumn{2}{|c|}{ OLS } & \multicolumn{2}{|c|}{ Tobit } \\
\hline & & Coef. & $\mathrm{p}$-value & Coef. & $\mathrm{p}$-value & Coef. & $\mathrm{p}$-value & Coef. & $\mathrm{p}$-value \\
\hline CONSTANT & + & 0.480 & 0.000 & 0.511 & 0.000 & 0.479 & 0.000 & 0.509 & 0.000 \\
\hline cow & - & -0.004 & 0.000 & -0.004 & 0.000 & -0.067 & 0.444 & -0.061 & 0.502 \\
\hline LAND & - & -0.00008 & 0.434 & -0.00014 & 0.219 & -0.0010 & 0.247 & -0.0002 & 0.078 \\
\hline FEED & - & -8.200 & 0.002 & -8.560 & 0.002 & -6.250 & 0.025 & -7.210 & 0.014 \\
\hline LABOUR & - & -9.330 & 0.000 & -0.00001 & 0.000 & -9.190 & 0.000 & -0.00001 & 0.000 \\
\hline MILK & + & 1.430 & 0.000 & 1.660 & 0.000 & 1.510 & 0.000 & 1.760 & 0.000 \\
\hline EDU2 & + & & & & & 0.054 & 0.116 & 0.056 & 0.122 \\
\hline EDU3 & + & & & & & 0.243 & 0.017 & 0.338 & 0.004 \\
\hline MSYS & - & & & & & -0.018 & 0.514 & -0.029 & 0.333 \\
\hline INS & - & & & & & -0.011 & 0.772 & -0.015 & 0.696 \\
\hline BREED & + & & & & & 0.062 & 0.476 & 0.057 & 0.536 \\
\hline $\begin{array}{l}\text { OTHERS } \\
\text { BREEDS }\end{array}$ & + & & & & & 0.062 & 0.474 & 0.056 & 0.539 \\
\hline SER & + & & & & & 0.098 & 0.001 & 0.097 & 0.001 \\
\hline $\mathrm{N}$ & & 253 & & 253 & & 253 & & 253 & \\
\hline
\end{tabular}

Model V introduces the variables COW, LAND and MILK to examine Hypothesis 2a (whether MTE varies according to farm size). The effect of COW are positive and statistically significant at $\mathrm{p}<0.001$ (Model V - OLS and Tobit). The regression coefficient for MILK is positive and statistically significant at p $<0.001$ (for Models V and VI - OLS and Tobit). Hypothesis 2a (MTE varies according to the farm size - COW and MILK) is confirmed. In contrast, the effect of LAND is not statistically significant for Model V (OLS and Tobit) and Model VI (OLS). Hypothesis 2a (MTE varies according to the farm size - LAND) is not confirmed.

The effect of FEED and LABOUR are statistically significant for Models V e VI (OLS and Tobit). It confirms H4a and H5a: MTE varies according to feed and labour costs. The coefficients for milking systems (MSYS), insemination (INS), Dutch breed (BREED) and others breed (OBREED) are not statistically significant, contrary to the expected result. H3a, H6a and H7a ("MTE varies according to use of milking systems, insemination and breed) are not confirmed.

Hypothesis 8a is confirmed, MTE varies according to use of services (SER). The coefficient for SER is positive and statistically significant at $\mathrm{p}<0.001$ for Model VI (OLS and Tobit), yielding higher MTE to dairy farm that uses technical assistance services. 
The comparison of the results of this study with previous results is summarized in Table 18. The first column presents the hypothesis tested, the other two columns indicate if the hypothesis was confirmed or not in the literature and fourth column presents the results of this study.

Table 18: Comparison of results (hypotheses)

\begin{tabular}{|c|c|c|c|}
\hline \multirow[b]{2}{*}{ Hypotheses } & \multicolumn{3}{|c|}{ Results } \\
\hline & Confirmed & Not Confirmed & $\begin{array}{l}\text { This } \\
\text { study }\end{array}$ \\
\hline $\begin{array}{l}\text { H1a: MTE varies } \\
\text { according to the } \\
\text { education of the } \\
\text { farm operator }\end{array}$ & $\begin{array}{l}\text { Kumbhakar et al. (1991), } \\
\text { Gonçalves et al. (2008), Chang } \\
\text { and Mishra (2011), Ma et al. } \\
\text { (2012), Nascimento et al. (2012), } \\
\text { Sauer and Latacz-Lohmann } \\
\text { (2013), Dong et al. (2013) }\end{array}$ & $\begin{array}{l}\text { Tauer and Belbase (1987), } \\
\text { Bravo-Ureta and Rieger } \\
\text { (1991), Tauer (1993), } \\
\text { Latruffe et al. (2004), } \\
\text { Gonçalves et al. (2008), } \\
\text { D'Haese et al. (2009), Gelan } \\
\text { and Muriithi (2012), } \\
\text { Nascimento et al. (2012), } \\
\text { Bardhan and Sharma } \\
\text { (2013), Dong et al. (2013), } \\
\text { Shortall and Barnes (2013) }\end{array}$ & Confirmed \\
\hline $\begin{array}{l}\text { H2a: MTE varies } \\
\text { according to farm } \\
\text { size (milk) }\end{array}$ & $\begin{array}{l}\text { Alvarez and González (1999), } \\
\text { Johansson (2005), Gonçalves et } \\
\text { al. (2008) }\end{array}$ & $\begin{array}{l}\text { Alvarez and González } \\
\text { (1999), Gonçalves et al. } \\
\text { (2008) }\end{array}$ & Confirmed \\
\hline $\begin{array}{l}\text { H2a: MTE varies } \\
\text { according to farm } \\
\text { size (land) }\end{array}$ & $\begin{array}{l}\text { Alvarez and González (1999), } \\
\text { Latruffe et al. (2004, 2005), Iráizoz } \\
\text { et al. (2005), Kompas and Che } \\
\text { (2006), Hadley (2001, 2006), } \\
\text { Barnes (2008), Rouse et al. } \\
\text { (2010), Del Corral et al. (2011), } \\
\text { Areal et al. (2012), Nascimento et } \\
\text { al. (2012), Dong et al. (2013), Ang } \\
\text { and Oude Lansink (2014), Luik et } \\
\text { al. (2014) }\end{array}$ & $\begin{array}{l}\text { Tauer and Belbase (1987), } \\
\text { Heshmati (1998), Alvarez } \\
\text { and González (1999), } \\
\text { Latruffe et al. (2004, 2005), } \\
\text { Iráizoz et al. (2005), Maietta } \\
\text { (2000), Hadley (2006), } \\
\text { Kompas and Chu (2006), } \\
\text { Hallam and Machado } \\
\text { (1996), Hansson (2007), } \\
\text { Gelan and Muriithi (2010), } \\
\text { Rouse et al. (2010), } \\
\text { Nascimento et al. (2012), } \\
\text { Bardhan and Sharma } \\
\text { (2013), Skevas et al. (2014) }\end{array}$ & $\begin{array}{c}\text { Not } \\
\text { confirmed }\end{array}$ \\
\hline $\begin{array}{l}\text { H2a: MTE varies } \\
\text { according to farm } \\
\text { size (number of } \\
\text { cows) }\end{array}$ & $\begin{array}{l}\text { Tauer and Belbase (1987), Bravo- } \\
\text { Ureta and Rieger (1990, 1991), } \\
\text { Kumbhakar et al. (1989, 1991), } \\
\text { Tauer (1993), Ahmad and Bravo- } \\
\text { Ureta (1996), Hallam and } \\
\text { Machado (1996), Heshmati (1998), } \\
\text { Alvarez and González (1999), } \\
\text { Brümmer and Loy (2000), Alvarez } \\
\text { and Arias (2004), Kompas and } \\
\text { Chu (2006), Hadley (2001, 2006), } \\
\text { Gelan and Muriithi (2012), Ma et } \\
\text { al. (2012), Nascimento et al. } \\
\text { (2012), Bardhan and Sharma } \\
\text { (2013), Shortall and Barnes } \\
\text { (2013), Dong et al. (2013), Jiang } \\
\text { and Sharp (2014), Luik et al. } \\
\text { (2014), Van der Voort et al. (2014) }\end{array}$ & $\begin{array}{l}\text { Alvarez and González } \\
\text { (1999), Bardhan and } \\
\text { Sharma (2013), Areal et al. } \\
\text { (2012), Luik et al. (2014), } \\
\text { Van der Voort et al. (2014) }\end{array}$ & Confirmed \\
\hline
\end{tabular}




\begin{tabular}{|c|c|c|c|}
\hline \multirow[b]{2}{*}{ Hypotheses } & \multicolumn{3}{|c|}{ Results } \\
\hline & Confirmed & Not Confirmed & $\begin{array}{l}\text { This } \\
\text { study }\end{array}$ \\
\hline $\begin{array}{l}\text { H3a: MTE varies } \\
\text { according to } \\
\text { milking systems }\end{array}$ & $\begin{array}{l}\text { Hansson (2007), Chidmi et al. } \\
\text { (2010), Del Corral et al. (2011) }\end{array}$ & $\begin{array}{l}\text { Tauer and Belbase (1987), } \\
\text { Tauer (1993), Cabrera et al } \\
(2010)\end{array}$ & $\begin{array}{c}\text { Not } \\
\text { confirmed }\end{array}$ \\
\hline $\begin{array}{l}\text { H4a: MTE varies } \\
\text { according to feed } \\
\text { costs }\end{array}$ & $\begin{array}{l}\text { Ahmad and Bravo-Ureta (1996), } \\
\text { Hallam and Machado (1996), } \\
\text { Kompas and Chu (2006), Cabrera } \\
\text { et al (2010), Chidmi et al. (2010), } \\
\text { Gelan and Muriithi (2010), Del } \\
\text { Corral et al. (2011), Michaličková } \\
\text { et al. (2013), Dong et al. (2013) }\end{array}$ & - & Confirmed \\
\hline $\begin{array}{l}\text { H5a: MTE varies } \\
\text { according to } \\
\text { labour costs }\end{array}$ & $\begin{array}{l}\text { Ahmad and Bravo-Ureta (1996), } \\
\text { Iráizoz et al. (2005), Gonçalves et } \\
\text { al. (2008), Chidmi et al. (2010), } \\
\text { Cabrera et al (2010), Del Corral et } \\
\text { al. (2011) } \\
\end{array}$ & $\begin{array}{l}\text { Hallam and Machado } \\
\text { (1996), Latruffe et al. (2004), } \\
\text { Michaličková et al. (2013) }\end{array}$ & Confirmed \\
\hline $\begin{array}{l}\text { H6a: MTE varies } \\
\text { according to use } \\
\text { of insemination }\end{array}$ & Alvarez and González (1999) & - & $\begin{array}{c}\text { Not } \\
\text { confirmed }\end{array}$ \\
\hline $\begin{array}{l}\text { H7a: MTE varies } \\
\text { according to } \\
\text { breed }\end{array}$ & $\begin{array}{l}\text { Hansson and Öhlmér (2008), } \\
\text { Gelan and Muriithi (2010) }\end{array}$ & Hansson and Öhlmér (2008) & $\begin{array}{c}\text { Not } \\
\text { confirmed }\end{array}$ \\
\hline $\begin{array}{l}\text { H8a: MTE varies } \\
\text { according to use } \\
\text { of services }\end{array}$ & $\begin{array}{l}\text { Bravo-Ureta and Rieger (1991), } \\
\text { Gonçalves et al. (2008), Chang } \\
\text { and Mishra (2011), Dong et al. } \\
\text { (2013), Uddin et al. (2014) }\end{array}$ & \begin{tabular}{|l|} 
Gonçalves et al. (2008), \\
Nascimento et al. (2012), \\
Michaličková et al. (2013), \\
Uddin et al. (2014)
\end{tabular} & Confirmed \\
\hline
\end{tabular}

As previously mentioned, it is readily apparent in Table 18 that different authors find different explanatory power for the same variable, which statistically affects TE in some studies but not in others. This makes the summary interpretation of the models at least difficult. Despite the lack of general agreement, results in this study show that dairy farms with high levels of TE tend to have higher quality of human capital in terms of educational training (H1a). The positive effects of education on efficiency are associated with the increases of productivity and more efficient use of new technologies (Chang \& Mishra, 2011; Sauer \& Latacz-Lohmann, 2013). Effective learning by using new dairy technologies appears to be inherently linked to the educational based background and behaviour (Foster \& Rosenzweig, 1995). In contrast, Tauer (1993, p. 8) says that "very little of the efficiencies from farm to farm were explained by characteristics of the farm" (e.g. age and education).

The variable farm size (H2a) has been widely examined and also show the lack of general agreement. Despite, in this study were found significant evidence 
(milk produced and number of cows) that large farms are more technically efficient than their smaller counterparts. A reason may be that bigger farms have greater feed costs and lower level of labour costs, as previously mentioned (subsection 5.1). Other reason for the greater efficiency in bigger farms can be technology. It is quite likely that the bigger farms invest more in technology (e.g. milking systems) and animal health (e.g. insemination, breed). Consequently, dairy farms need a higher quality of human capital in terms of educational training. This means that they have had to improve their management skills in order to make their farms survive.

Another reason in relation to management may be that the small and middle sized farms need to complement the family income with off-farm work. This situation increases the labour costs (characteristics of DMUs less efficient Table 12, subsection 5.1), because in order to meet the demands of activity the farmers need to hire workers. This means that the family is not completely dependent on the farm in order to earn their living, and then can afford to let the production be inefficient (Johansson, 2005). Blank (2005) maintained that small and middle sized farms maximise their family wealth rather than their farm income. Surprisingly, however, the breed (H7a), the use of milking systems (H3a) and insemination (H6a) were statistically non-significant in this study. In Table 18, one can verify that few authors evaluated these variables and, different explanatory power for the same variables was found. From the results, TE in dairy farms could benefit from future research in a deeper analysis of variables mentioned.

The feed and labour costs variables (H4a and $\mathrm{H} 5 \mathrm{a}$ ) showed a most general agreement between authors. The empirical results show that the intensification of feed variable implies improvement in efficiency levels. The same outcomes were found in Hallam and Machado (1996) for Portuguese dairy farms, in Kompas and Che (2006) for Australian dairy farms and in Cabrera et al. (2010) for Wisconsin dairy farms. In relation to the labour variable, Gonçalves et al. (2008) and this empirical study concluded that labour contributed positively to technical efficiency. Chidmi et al. (2010), Del Corral et al. (2011) and Nascimento et al. (2012) used the family labor variable. The greater the percentage of family labour a farm uses, the less technically efficient the farm is (Del Corral et al., 2011). 
Cuesta (2000, p. 147) argues "the labour variable should be viewed with caution because the farms in the sample are family farms and the labour variable could be reflecting a disguised unemployment problem”. One the other hand, Cabrera (2010, p. 391) argues that "the empirical results clearly show that a higher proportion of family labour over the total labour leads to increase TE” and that their result agrees with Carter (1984). The argument is that family members seek to maximize family welfare and consequently provide a greater effort toward production. As previously mentioned, different authors find different explanatory power for the same variable, which statistically affects TE in some studies but not in others.

Finally, the services variable (e.g., nutritionists and veterinarians) is also important for production efficiency. The farms using services had higher TE scores. This result was found in Bravo-Ureta and Rieger (1991), Gonçalves et al. (2008), Chang and Mishra (2011), Dong et al. (2013) and in this study. Dong et al. (2013) argues that generally large farms utilize services and this indirectly explains why large farms are more technical efficient. In contrary, in this study only 23 more efficient dairy farms (47.9\% of the 48 dairy farms achieved TE levels of 0.75 or higher to CRS models) use services and their size varies from 12 to 310 (number of cows).

\section{4}

\section{Discussions}

This chapter presented an empirical study aiming at measuring and understanding the factors affecting the TE in dairy farms of selected municipalities in the South of Brazil. This study used primary data from a survey undertaken in 2010 in 14 municipalities of the State of Rio Grande do Sul / Brazil - Regional Council Development of Alto Jacuí (COREDE Alto Jacuí). The empirical study was developed in two-stages. In the first stage, a DEA model was used to estimate the TE level of the dairy farms selected in municipalities of the South of Brazil. Then from the primary data two regression models are estimated to test the hypotheses that emerged from the research synthesis. 
Regarding the distribution of MTE level, results show that approximately $19 \%$ and $26 \%$ of the dairy farms achieved TE levels of 0.75 or higher. On the other hand, most of the dairy farms (45.8\%, 55.3\% and 51.4\%) achieved TE levels of 0.25 to 0.49 . These inefficient farms were benchmarked and the total potential improvements to TE level of each variable of model were: feed costs (-25.11\%), land (-24.11\%), labour costs (-22.15\%) and cow (-21.12\%). These reductions in the inputs will result in increase of the outputs: milk production $(2.42 \%)$ and bonus (5.08\%). The benchmark analysis is a way of improving the TE level. The mensuration of the level of TE combined with benchmark analysis helps producers to improve their degree of efficiency. They identify how efficiency can be improved when eliminating the excessive use of inputs. The TE level of this empirical study is similar to the study of Sousa et al. (2012) (54.5\%), made in the state of Goiás/Brazil. These variations in average efficiency among the studies reflects different regions of Brazil, different time periods, differences in input and output selections, and differences in sample size. The hypothesis are that these variation in the MTE of the dairy farms can be explained by attributes of the studies, including education, farm size (land, cow and milk), milking systems, insemination, breeding and services. Two regression models were estimated. In this study, the results show that MTE varies according to the: education of the farm operator (H1a), number of cow and milk produced (H2a), feed (H4a) and labour (H5a) costs, use of services (H8a).

Findings from this study have important implications for both policy formulation and farm management. The policymakers could use this knowledge to identify and target public interventions to improve productivity and the competitiveness of dairy farms especially in relation to services (e.g. nutritionists and veterinarians). The producers provided the evidences to improve the TE level of the dairy farms, such as: quality of human capital in terms of educational training, use of new technologies and intensification of feed costs. These results benefit directly the development of dairy farms because efficient farms tend to generate higher incomes and thus have a better chance of surviving and staying in business. Finally, this study makes two important contributions to the literature: (i) the hypotheses developed earlier were tested in the empirical investigation of 
TE in dairy farms of municipalities in the South of Brazil and (ii) the understanding of TE in dairy farms of municipalities in the South of Brazil. 


\section{Conclusions}

This thesis develops a research synthesis on TE in dairy farms conducting both a meta-synthesis and a meta-regression analysis and measures and understands the factors that affect the TE in dairy farms, conducting an empirical study in selected municipalities in the South of Brazil. The goal of the metasynthesis is to integrate the findings of 103 existing studies about TE in dairy farms through a systematic literature review, offering a research synthesis framework as a structuring tool to assemble TE descriptors from the extant literature. Mean TE, its determinants and measurement techniques were reviewed and synthesized. Main determinants of TE are geographical location, farm size, investments in veterinary care, feeding, milking practices, model estimation techniques, public policy, and management. One striking feature that emerges from the literature is the lack of consensus about measurement techniques and determinants of TE, which remains an open debate. As there is no agreement among authors, the analysis of determinants, metrics, inputs and output variables led to verifiable research propositions.

In addition a meta-regression analysis is applied to analyse the effects that these different methodologies and study-specific characteristics have on the mean TE (MTE). This analysis makes two important contributions: (i) it updates and compares previous works on frontier estimation of TE in dairy farms and (ii) it adds two dimensions of dairy farms: size (herd and land area) and economic development, to the known differentials of TE measurement. The variation in the MTE indexes reported in the literature can be explained by the methodology of estimations (method of estimation, functional form of frontier models, model dimensionality), the farms geographical location and farm size. Additionally, the results suggest that, given the state of technology prevailing in each country at the time that the studies on TE were conducted, dairy farmers in the sample could increase milk output by $20.1 \%$ (level of inefficiency), on average, if they produce on their frontiers. 
The empirical study measures and understands the factors affecting the TE in dairy farms of municipalities in the south of Brazil. Firstly, a DEA model was used to estimate the TE level of the dairy farms and identified those with the best practices (benchmarks). The measurement of TE level combined with the analysis of best practices helps farmers improve their efficiency. Then using two metaregression models, the empirical study supported the understanding of the main factors affecting this TE, and tested the hypotheses that emerged from the research synthesis. This study makes important contributions to the literature: the propositions and hypothesis are tested.

This thesis makes seven important contributions to the literature: (i) a conceptual research synthesis framework is proposed as a structuring tool to assemble TE descriptors from the extant literature; (ii) from the empirical results in dairy farms, the determinants, inputs, outputs and measurement techniques were synthesized; (iii) it adds two dimensions for meta-regression of dairy farms to the known differentials of TE measurement (size and economic development); (iv) it updates and compares previous work on frontier estimation of TE in dairy farms; (v) propositions and hypothesis were presented and developed analysing the effects of different methodologies and study-specific characteristics on MTE; (vi) the hypothesis were tested in the empirical investigation of TE in dairy farms of municipalities in the South of Brazil, offering a new empirical study in a region that has not been frequently chosen as object of study and, therefore, (vii) contributes to the understanding of TE in dairy farms of municipalities in the South of Brazil.

Findings from this study have important implications for both policy formulation and farm management. The policy makers could use this knowledge to identify and target public interventions to improve productivity and the competitiveness of dairy farms especially in relation to human resources development through extension services. The fact that larger farms seem to be comparative by better than small farms in terms of TE stresses the need for public policies aiming at increasing mean TE in this segment. In addition, available evidence shows that best management practices can be benchmarked and lead to substantive gains in productivity. To producers were provided evidence to improve the TE level of the dairy farms, such as: quality of human capital in terms 
of educational training, use new technologies and intensification of feed costs. This results benefit directly the developed of dairy farms because efficient farms tend to generate higher incomes and thus have a better chance of surviving and staying in business.

Despite the growing literature on the subject, TE in dairy farms could benefit from future research in the following six areas: analysis of the impact of different measurement techniques on resulting mean TE; investigation of the variables that can mediate or moderate the relationship between determinants and mean TE; development of benchmarks based on best management practices; test of the hypotheses that emerged from the research synthesis; the analysis of the impact of different research years and if it affects the results significantly; development of sensibility analysis to improve TE levels. Dairy farms are important components of rural production all over the world. Measuring efficiency and explaining its determinants are the first steps to achieve important economic gains and to remain competitive in nowadays markets. The analysis of benchmarks (best practices) may lead to substantial resource savings, with important implications to improve management, and therefore the productivity and competitiveness of dairy farms. 


\section{References}

AHMAD, M.; BRAVO-URETA, B. E. Technical efficiency measures for dairy farms using panel data: a comparison of alternative model specifications. Journal of Productivity Analysis, 7, 1996. 399-415.

AIGNER, D.; LOVELL, K.; SCHMIDT, R. Formulation and Estimation of Stochastic Frontier Production Function Models. Journal o f Econometrics, 6, 1977. 21-37.

ALVAREZ, A.; ARIAS, C. Technical efficiency and farm size: a conditional analysis. Agricultural Economics, 30, 2004. 241-250.

ÁLVAREZ, A.; GONZÁLEZ, E. Using cross-section data to adjust technical efficiency indexes estimated with panel data. American Journal of Agricultural Economics, 81, 1999. 894-901.

ALVAREZ, A.; OREA, L. Different approaches to model multispecies fisheries using primal approach. Economia Agraria y Recursos Naturales, 2, 2002. 5-20.

ANG, F.; OUDE LANSINK, A. Dynamic Profit Inefficiency: A DEA Application to Belgian Dairy Farms. In: EAAE Anais. Ljubljana: Congress Agri-Food and Rural innovations for HealthierSocieties', 2014. Disponivel em: $<$ http://ageconsearch.umn.edu/bitstream/182649/2/Ang-

Dynamic_profit_inefficiency-386_a.pdf.>. Acesso em: 25 set. 2014.

ANGÓN, E.; GARCÍA, A.; PEREA, J.; ACERO, R.; TORO-MÚJICA, P.; PACHECO, H.; GONZÁLEZ, A. Technical efficiency and viability of grazing dairy cattle systems in La Pampa, Argentine. Agrociencia, 47, n. 5, 2013. 443456.

AREAL, F.J.; TIFFIN, R.; BALCOMBE, K.G. Provision of environmental output within a multi-output distance function approach. Ecological Economics, 78, 2012. 47-54.

ASMILD, M.; HOUGAARD, J.L.; KRONBORG, D.; KVIST, H.K. Measuring inefficiency via potential improvements. Journal of Productivity Analysis, 19, 2003. 59-76.

BAILEY, D.; BISWAS, B.; KUMBHAKAR, S.C.; SCHULTHIES, B.K. An analysis of technical, allocative, and scale inefficiency: the case of Ecuadorian dairy farms. Western Journal of Agricultural Economics, 14, 1989. 30-37.

BALCOMBE, K.; FRASER, I.; KIM, J.H. Estimating technical efficiency of Australian dairy farms using alternative frontier methodologies. Applied Economics, 38, 2006. 2221-2236. 
BANKER, R.D.; NATARAJAN, R. Evaluating contextual variables affecting productiv- ity using data envelopment analysis. Operations Research, 56, n. 1, 2008. 48-58.

BARDHAN, D.; SHARMA, M.L. Technical efficiency in milk production in underdeveloped production environment of India. SpringerPlus, 2, 2013. 1-7.

BARNES, A.P. Technical efficiency estimates of Scottish agriculture: a note. Journal of Agricultural Economics, 59, 2008. 370-376.

BARNES, A.P.; RUTHERFORD, K.M.D.; LANGFORD, F.M.; HASKELL, M.J. The effect of lameness prevalence on technical efficiency at the dairy farm level: An adjusted data envelopment analysis approach. Journal of Dairy Science, 94, 2011. 5449-5457.

BATTESE, G.E. Frontier production functions and technical efficiency: a survey of empirical applications in agricultural economics. Agricultural Economics, 7, 1992. 185-208.

BATTESE, G.E.; COELLI, T.J. Prediction of firm-level technical efficiencies with a generalized frontier production function and panel data. Journal of Econometrics, 38, 1988. 387-399.

BATTESE, G.E.; COELLI, T.J. Frontier Production Functions, Technical Efficiency and Panel Data: With Application to Paddy Farmers in India. Journal of Productivity Analysis, 3, 1992. 153-169.

BATTESE, G.E.; COELLI, T.J. A model for technical inefficiency effects in a stochastic frontier production function for panel data. Empirical Economics, 1995. 325-332.

BHATT, M.S.; BHAT, S.A. Technical Efficiency And Farm Size Productivity Micro Level Evidence From Jammu \& Kashmir. International Journal of Food and Agricultural Economics, 4, 2014. 27-49.

BLANK, S.C. The business of an agricultural "way of life”. Choices, 2, 2005. 161-166.

BOJNEC, Š.; LATRUFFE, L. Measures of farm business efficiency. Industrial Management \& Data Systems, 108, 2008. 258-270.

BRAVO-URETA, B.E.; SOLÍS, D.; MOREIRA LÓPEZ, V.H.; MARIPANI, J. F.; THIAM, A.; RIVAS, T. Technical efficiency in farming: a meta-regression analysis. Journal of Productivity Analysis, 27, 2007. 57-72.

BRAVO-URETA, B.E.; MOREIRA, V.H.; ARZUBI, A.A.; SCHILDER, E.D.; ÁLVAREZ, J.; MOLINA, C. Technological change and technical efficiency for dairy farms in three countries of South America. Chilean Journal Agricultural Research, 68, 2008. 360-367. 
BRAVO-URETA, B.E.; PINHEIRO, A.E. Efficiency analysis of developing country agriculture: a review of the frontier function literature. Agricultural and Resource Economics Review, 22, 1993. 88-101.

BRAVO-URETA, B.E.; RIEGER, L. Alternative production frontier methodologies and dairy farm efficiency. Journal of Agricultural Economics, 41, 1990. 215-226.

BRAVO-URETA, B.E.; RIEGER, L. Dairy farm efficiency measurement using stochastic frontiers and neoclassical duality. American Journal of Agricultural Economics, 73, 1991. 421-428.

BRÜMMER, B.; GLAUBEN, T.; THIJSSEN, G. Decomposition of productivity growth using distance functions: the case of dairy farms in three European countries. American Journal Agricultural Economics, 84, 2002. 628-644.

BRÜMMER, B.; LOY, J.P. The technical efficiency impact of farm credit programmes: A case study of northern Germany. Journal of Agricultural Economics, 51, 2000. 405-418.

CABRERA, V.E.; SOLÍS, D.; DEL CORRAL, J. Determinants of technical efficiency among dairy farms in Wisconsin. Journal of Dairy Science, 93, 2010. 387-393.

CARTER, M.R. Resource allocation and use under collective rights and labour management in Peruvian coastal agriculture. The Economic Journal, 1984. 826846.

CHANG, H.H.; MISHRA, A.K. Does the Milk Income Loss Contract program improve the technical efficiency of US dairy farms? Journal of Dairy Science, 94, 2011. 2945-2951.

CHARNES, A.; COOPER, W.W.; RHODES, E. Measuring the efficiency of decision making units. European Journal of Operational Research, 2, n. 6, 1978. 429-444.

CHAVAS, J.P.; PETRIE, R.; ROTH, M. Farm Household Production Efficiency: Evidence from the Gambia. American Journal of Agricultural Economics, 87, 2005. 160-179.

CHIDMI, B.; SOLÍS, D.; FUNTANILLA, M.; CABRERA, V.E. Analyzing the Determinants of Technical Efficiency Among Traditional Dairy Farms in Wisconsin: A Quantile Regression Approach. In: AAEA Anais. Denver: Agricultural and Applied Economics Associations, 2010. p. 1-20. Disponivel em: $<$ http://ageconsearch.umn.edu/bitstream/61320/2/11669.pdf $>$. Acesso em: 13 May 2014.

COELLI, T.J. Recent developments in frontier modelling and efficiency measurement. Australian Journal of Agricultural Economics, 39, 1995. 219245. 
COELLI, T.J.; RAO, D.S.P.; O'DONNELL, C.J.; BATTESE, G.E. An Introduction to Efficiency and Productivity Analysis. New York: Springer, 2005.

COOPER, H. Research synthesis and meta-analysis: A step-by-step approach. Thousand Oaks: Applied Social Research Methods Series, 2 Sage Publications, 2010.

CORREAA, J.C.S.; SILVA, E.M.T.; TAVARES, C.E.M.; MARETH, T. Planejamento estratégico de desenvolvimento regional. Cruz Alta: Unicruz, 2010.

CUESTA, R.A. A production model with firm-specific temporal variation in technical inefficiency: with application to Spanish dairy farms. Journal of Productivity Analysis, 13, 2000. 139-158.

D'HAESE, M.; SPEELMAN, S.; ALARY, V.; TILLARD, E.; D'HAESE, L. Efficiency in milk production on Reunion Island: Dealing with land scarcity. Journal of Dairy Science, 92, 2009. 3676-3683.

DAWSON, P.J.; LINGARD, J.; WOODFORD, C.H. A generalized measure of farm-specific technical efficiency. American Journal Agricultural Economics, 73, 1991. 1098-1104.

DAWSON, P.J.; WHITE, B. The post-quota performance of dairy farms in England and Wales. Applied Economics, 22, 1990. 1399-1406.

DEBREU, G. The coefficient of resource utilization. Econometria, 19, 1951. 273-292.

DEL CORRAL, J.; PEREZ, J.A.; ROIBAS, D. The impact of land fragmentation on milk production. Journal of Dairy Science, 94, 2011. 517-525.

DONG, F.; HENNESSY, D.; JENSEN, H.H. Size, Productivity and Exit Decisions in Dairy Farms. In: AAEA Anais. Washington: Annual Meeting Agricultural \& Applied Economics Associantion's, 2013. Disponivel em: $<$ http://ageconsearch.umn.edu/bitstream/150339/2/AAEA\%202013dairy\%20farm_06012013.pdf>. Acesso em: 13 May 2014.

ESTEBAN GARCIA, J.; COLL SERRANO, V. Competitividad y Eficiencia. Estudios de Economia Aplicada, 21, 2003. 423-450.

FAEMG. Diagnóstico da pecuária leiteira do estado de Minas Gerais em 2005: relatório de pesquisa. Belo Horizonte, p. 156. 2006.

FAO, F. Statistical Yearbook 2013: World Food and Agriculture. Rome. 2013.

FARRELL, M.J. The measurement of productive efficiency. Journal of the Royal Statistical Society, 120, 1957. 253-290.

FERREIRA, C.M.C.; GOMES, A.P. Introdução à análise envoltória de dados: teoria, modelos e aplicações. Viçosa: UFV, 2009. 389 p. 
FOGARASI, J.; LATRUFFE, L. Technical efficiency and technology in Eastern and Western agriculture: A comparison of crop and dairy farms in Hungary and France. In: EAAE Anais. Budapest: Seminar Agricultural Economics and Transition, 2007a. Disponivel em: <http://ageconsearch.umn.edu/bitstream/7810/1/sp07fo01.pdf.>. Acesso em: 13 maio 2014.

FOGARASI, J.; LATRUFFE, L. Technical efficiency and productivity change of dairy farms: A comparison of France and Hungary. In: EAAE Anais. Barcelona: Mediterranean Conference of Agro-Food Social Scientists, 2007b. Disponivel em: $<$ http://ageconsearch.umn.edu/bitstream/9432/1/sp07fo01.pdf.>. Acesso em: 13 maio 2014.

FOGARASI, J.; LATRUFFE, L. Technical efficiency in dairy farming: A comparison of France and Hungary in 2001-2006. Studies in Agricultural Economics, 110, 2009. 75-84.

FOSTER, A.; ROSENZWEIG, M. Learning by Doing and Learning from Others: Human Capital and technical change in agriculture. Journal of Political Economy, 103, 1995. 1176-1209.

FRASER, I.; CORDINA, D. An application of data envelopment analysis to irrigated dairy farms in Northern Victoria, Australia. Agricultural Systems, 59, 1999. 267-282.

FRIED, H.O.; LOVELL, C.A.K.; SCHMIDT, S.S.; YAISAWARNG, S. Accounting for environ- mental effects and statistical noise in data envelopment analysis. Journal of Productivity Analysis, 17, n. 1-2, 2002. 157-174.

GELAN, A.; MURIITHI, B.W. Measuring and explaining technical efficiency of dairy farms: a case study of smallholder farms in East Africa. Agrekon, 51, 2010. 53-74.

GHOSH, S.; MCGUCKIN, J.T.; KUMBHAKAR, S.C. Technical efficiency, risk attitude, and adoption of new technology: the case of the US dairy industry. Technological Forecasting and Social Change, 46, 1994. 269-278.

GONÇALVES, R.M.L.; VIEIRA, W.D.C.; LIMA, J.E.D.; GOMES, S.T. Analysis of technical efficiency of milk-producing farms in Minas Gerais. Economia Aplicada, 12, n. 2, 2008. 321-335.

GREENE, W. Econometric analysis. 5. ed. [S.l.]: Pearson Education, 2002.

GREENE, W. Econometric Analysis. 6. ed. [S.l.]: Pearson Education, 2008.

GREENE, W.H. The Econometric Approach to Efficiency Analysis. In: FRIED, H.O.; LOVELL, C.A.K.; SCHMIDT, S.S. The measurement of productive efficiency: techniques and applications. New York: Oxford University Press, 1993. p. 67-119. 
HADLEY, D. Patterns in Technical Efficiency and Technical Change at the Farmlevel in England and Wales, 1982-2002. Journal of Agricultural Economics, 57, 2006. 81-100.

HADLEY, D.; SHANKAR, B.; THIRTLE, C.; COELLI, T.J. Financial exposure and farm efficiency: Evidence from the England and Wales dairy sector. In: AAEA Anais. Chicago: American Agricultural Economics Association, 2001. Disponivel em: <http://ageconsearch.umn.edu/bitstream/20656/1/sp01ha07.pdf.>. Acesso em: 13 maio 2014.

HAGHIRI, M.; NOLAN, J.F.; TRAN, K.C. Assessing the impact of economic liberalization across countries: a comparison of dairy industry efficiency in Canada and the USA. Applied Economics, 36, 2004. 1233-1243.

HALLAM, D.; MACHADO, F. Efficiency analysis with panel data: A study of Portuguese dairy farms. European Review of Agricultural Economics, 23, 1996. 79-93.

HANSSON, H. Strategy factors as drivers and restraints on dairy farm performance: Evidence from Sweden. Agricultural systems, 94, 2007. 726-737.

HANSSON, H.; ÖHLMÉR, B. The effect of operational managerial practices on economic, technical and allocative efficiency at Swedish dairy farms. Livestock Science, 118, 2008. 34-43.

HESHMATI, A. Efficiency measurement in rotating panel data. Applied Economics, 30, 1998. 919-930.

HESHMATI, A.; KUMBHAKAR, S. C. Farm heterogeneity and technical efficiency: some results from Swedish dairy farm. Journal Productivity Analysis, 5, 1994. 45-61.

HOFF, A. Second Stage DEA: Comparison of Approaches for Modelling the DEA Score. European Journal of Operational Research, 181, 2006. 425-35.

IBGE. IBGE, Diretoria de Pesquisas, Coordenação de Agropecuária, Pesquisa da Pecuária Municipal 2011. Obtido em:, 2011. Disponivel em: <ftp://ftp.ibge.gov.br/Producao_Pecuaria/Producao_da_Pecuaria_Municipal/2011/ tabelas_pdf/tab23.pdf $>$. Acesso em: 2 Junho 2015.

IRÁIZOZ, B.; BARDAJI, I.; RAPUN, M. The Spanish beef sector in the 1990s: impact of the BSE crisis on efficiency and profitability. Applied Economics, 37, 2005. 473-484.

JAFORULLAH, M.; WHITEMAN, J. Scale Efficiency in the New Zealand Dairy Industry: a Non-parametric Approach. Australian Journal of Agricultural and Resource Economics, 43, 1999. 523-541.

JIANG, N.; SHARP, B. Cost Efficiency of Dairy Farming in New Zealand: a stochastic frontier analysis. Agricultural and Resource Economics Review, 43, n. 3, 2014. 406-418. 
JOHANSSON, H. Technical, allocative, and economic efficiency in Swedish dairy farms: The data envelopment analysis versus the stochastic frontier approach. In: EAAE Anais. Copenhagen: International Congress of the European Association of Agricultural Economists, 2005. Disponivel em: $<$ http://ageconsearch.umn.edu/bitstream/24478/1/pp05jo03.pdf $>$. Acesso em: 13 May 2014.

KARAGIANNIS, G.; MIDMORE, P.; TZOUVELEKAS, V. Separating technical change from time-varying technical inefficiency in the absence of distributional assumptions. Journal of Productivity Analysis, 2002. 23-38.

KEIZER, T.H.; EMVALOMATIS, G. Differences in TFP growth among groups of dairy farms in the Netherlands. NJAS-Wageningen Journal of Life Sciences, 2014.

KELLERMANN, M.; SALHOFER, K. Dairy farming on permanent grassland: Can it keep up? Journal of dairy science, 97, n. 10, 2014. 6196-6210.

KOMPAS, T.; CHE, T.N. Technology choice and efficiency on Australian dairy farms. Australian Journal of Agricultural and Resource Economics, 50, 2006. 65-83.

KOOPMANS, T. C. Na analysis of production as an efficient combination of activities. In: KOOPMANS, T. C. Activity analysis of production and allocation. New York: Wiley, 1951. p. Monograph No. 13.

KOVACS, K.; EMVALOMATIS, G. Dutch, Hungarian and German dairy farms technical efficiency comparison. APSTRACT: Applied Studies in Agribusiness and Commerce, 5, 2011.

KUMBHAKAR, S.C.; BISWAS, B.; VON BAILEY, D. A study of economic efficiency of Utah dairy farmers: a system approach. The Review of Economics and Statistics, 71, 1989. 595-604.

KUMBHAKAR, S.C.; GHOSH, S.; MCGUCKIN, J. A generalized production frontier approach for estimating determinants of inefficiency in U.S. dairy farms. Journal of Business \& Economics Statistics, 9, 1991. 279-286.

KUMBHAKAR, S.C.; HESHMATI, A. Efficiency measurement in Swedish Dairy Farms: an application of rotating panel data, 1976-88. American Journal Agricultural Economics, 77, 1995. 660-674.

KUMBHAKAR, S.C.; TSIONAS, E.G.; SIPILÄINEN, T. Joint estimation of technology choice and technical efficiency: an application to organic and conventional dairy farming. Journal of Productivity Analysis, 31, n. 3, 2009. 151-161.

LATRUFFE, L.; BALCOMBE, K.; DAVIDOVA, S.; ZAWALINSKA, K. Determinants of technical efficiency of crop and livestock farms in Poland. Applied Economics, 36, 2004. 1255-1263. 
LATRUFFE, L.; BALCOMBE, K.; DAVIDOVA, S.; ZAWALINSKA, K. Technical and scale efficiency of crop and livestock farms in Poland: does specialization matter? Agricultural Economics, 32, 2005. 281-296.

LATRUFFE, L.; FOGARASI, J.; DESJEUX, Y. Efficiency, productivity and technology comparison for farms in Central and Western Europe: The case of field crop and dairy farming in Hungary and France. Economic Systems, 36, 2012. 264-278.

LIPSEY, M.W.; WILSON, D.B. Practical meta-analysis. Thousand Oaks: Sage, 2001.

LIU, J.S.; LU, L.Y.; LU, W.M.; LIN, B.J. Data envelopment analysis 1978-2010: A citation-based literature survey. Omega, 41, n. 1, 2013. 3-15.

LOPES, F. Technical Efficiency in Portuguese Dairy Farms. In: ACAES Anais. Portugal: Annual Conference of the Agricultural Economics Society, 2008. p. 120. Disponivel em: < http://ageconsearch.umn.edu/bitstream/36863/2/lopes.pdf>. Acesso em: 13 May 2014.

LORENZONI, A.; MERA, C.M.P.; ARALDI, D.F. Diagnóstico das unidades de produção leiteira dos municípios da Região do Corede Alto Jacuí-RS. Cruz Alta: Universidade de Cruz Alta, 2012.

LOVELL, K. Applying Efficiency Measurement Techniques to the Measurement of Productivity Change. Journal of Productivity Analysis, 7, 1996. 329-340.

LUIK, H.; VIIRA, A.H.; VÄRNIK, R. Using the information about dairy herd's genetic level and milk quality in explaining the technical efficiency of Estonian dairy farms: a two-stage (DEA and Tobit) approach. In: EAAE Anais. Ljubljana: Congress Agri-Food and Rural innovations for Healthier Societies, 2014. Disponivel em: <http://ageconsearch.umn.edu/bitstream/182650/2/LuikUsing_the_information_about_dairy_herd\%E2\%80\%99s_genetic_level_and_milk _quality-492_a.pdf.>. Acesso em: 25 set. 2014.

MA, H.; OXLEY, L.; RAE, A.; FAN, C.; HUANG, J.; ROZELLE, S. The evolution of productivity performance on China's dairy farms in the new millennium. Journal of Dairy Science, 95, 2012. 7074-7085.

MAGALHÃES, K.A.; CAMPOS, R.T. Eficiência técnica e desempenho econômico de produtores de leite no Estado do Ceará, Brasil. Revista de Economia e Sociologia Rural, 44, n. 4, 2006. 695-711.

MAIETTA, O.W. The decomposition of cost inefficiency into technical and allocative components with panel data of Italian dairy farms. European Review of Agricultural Economics, 27, 2000. 473-495.

MAMARDASHVILI, P.; JAN, P. Environmentally harmful by-products in efficiency analysis: An example of nitrogen surplus on Swiss dairy farms. In: EAAE Anais. Ljubljana: Congress Agri-Food and Rural innovations for Healthier Societies, 2014. Disponivel em: 
$<$ http://ageconsearch.umn.edu/bitstream/182910/2/14th_EAAE_Congress__Poster_paper_Mamardashvili.pdf.>. Acesso em: 25 set. 2014.

MARETH, T. et al. Systematic Review and Meta-Regression Analysis of Technical Efficiency in Dairy Farms. International Journal of Productivity and Performance Management, 2015.

MARETH, T.; PAIM, E.S.E. Estudo de indicadores de eficiência nas Unidades de produção leiteira dos Municípios do Corede Alto Jacuí-RS. Cruz Alta: Universidade de Cruz Alta, 2012.

MAYEN, C.D.; BALAGTAS, J.V.; ALEXANDER, C.E. Technology adoption and technical efficiency: organic and conventional dairy farms in the United States. American Journal of Agricultural Economics, 92, 2010. 181-195.

MAYRING, P. Qualitative Content Analysis. Forum Qualitative Sozialforschung / Forum: Qualitative Social Research, 1, n. 2, 2000. Disponivel em: <http://www.qualitativeresearch.net/index.php/fqs/article/view/1089/2385>.

MBAGA, M.D.; ROMAIN, R.; LARUE, B.; LEBEL, L. Assessing technical efficiency of Quebec dairy farms. Canadian Journal of Agricultural Economics, 51, 2003. 121-137.

MCDONALD, J. Using least squares and tobit in second stage DEA efficiency analyses. European Journal of Operational Research, 197, 2009. 792-798.

MEEUSEN, W.; VAN DEN BROECK, J. Efficiency Estimation From CobbDouglas Production Function: With Composed Error. International Economics Review, 18, 1977. 435-44.

MICHALIčKOVÁ, M.; KRUPOVÁ, Z.; KRUPA, E. Technical efficiency and its determinants in dairy cattle. Acta Oeconomica et Informatica, 16, 2013. 2-12.

MINEGISHI, K. Explaining Production Heterogeneity By Contextual Environments: Two-Stage DEA Application to Technical Change Measurement. In: AAEA Anais. Washington: Annual Meeting - Agricultural \& Applied Economics Associations, 2013. Disponivel em: $<$ http://ageconsearch.umn.edu/bitstream/150289/2/draft_technical_change_Jun_3 2013.pdf.>. Acesso em: 13 maio 2014.

MOREIRA LÓPEZ, V.H. Dairy farm technical efficiency and milk total factor productivity growth in three South American countries. Connecticut: Dissertation, University of Connecticut, 2006. 162 p.

MOREIRA LÓPEZ, V.H.; BRAVO-URETA, B.E.; ARZUBI, A.; SCHILDER, E. Multi-output technical efficiency for Argentinean dairy farms using stochastic production and stochastic distance frontiers with unbalanced panel data. Economia Agraria, 10, 2006a. 97-10.

MOREIRA LÓPEZ, V.H.; BRAVO-URETA, B.E.; CARRILLO, B.L.; VÁSQUEZ, J.A. Medidas de eficiencia técnica para pequeños productores de 
leche del Sur de Chile: Un análisis con fronteras estocásticas y datos de panel desbalanceado. Archivos de medicina veterinaria, 38, 2006b. 25-32.

MOREIRA LÓPEZ, V.H.; BRAVO-URETA, B.E. A study of dairy farm technical efficiency using meta-regression: An international perspective. Chilean Journal Agricultural Research, 69, 2009. 214-223.

MOREIRA LÓPEZ, V.H.; BRAVO-URETA, B.E. Technical efficiency and metatechnology ratios for dairy farms in three southern cone countries: a stochastic meta-frontier model. Journal of Productivity Analysis, 33, n. 1, 2010. 33-45.

MUGERA, A.W. Measuring technical efficiency of dairy farms with imprecise data: a fuzzy data envelopment analysis approach. Australian Journal of Agricultural and Resource Economics, 57, 2011. 501-520.

NASCIMENTO, A.C.C.; LIMA, J.E.; BRAGA, M.J.; NASCIMENTO, M.; GOMES, A.P. Eficiência técnica da atividade leiteira em Minas Gerais: uma aplicação de regressão quantílica. Revista Brasileira de Zootecnia, 41, n. 3, 2012. 783-789.

NEHRING, R.; GILLESPIE, J.; SANDRETTO, C.; HALLAHAN, C. Small US dairy farms: can they compete? Agricultural Economics, 40, 2009. 817-825.

NEUENDORF, K.A. The Content Analysis Guidebook. Thousand Oaks: Sage Publications, 2002.

ODENING, M.; WAGNER, C.; NARAYANA, R.; HUETTEL, S. Measuring Dynamic Efficiency under Uncertainty: An Application to German Dairy Farms. In: AAEA Anais. Washington: Annual Meeting - Agricultural \& Applied Economics Associations, 2013. Disponivel em: $<$ http://ageconsearch.umn.edu/bitstream/149632/2/AAEA_WagnerHuettelOdenin gNarayana.pdf.>. Acesso em: 13 maio 2014.

OHLAN, R. Efficiency and Total Factor Productivity Growth in Indian Dairy Sector. Quarterly Journal of International Agriculture, 52, 2013. 51-77.

OLESEN, O.; PETERSEN, N.; LOVELL, C. Editor's introduction. Journal of Productivity Analysis, 7, 1996. 87-98.

OREA, L.; ROIBÁS, D.; WALL, A. Choosing the technical efficiency orientation to analyze firms' technology: a model selection test approach. Journal of Productivity Analysis, 22, 2004. 51-71.

PIERALLI, S.; HÜTTEL, S.; ODENING, M. Abandonment of milk production under uncertainty and inefficiency: The case of West German farms. In: AAEA Anais. Minneapolis: Annual Meeting - Agricultural \& Applied Economics Association's, 2014. p. $1-21$. Disponivel em: $<$ http://ageconsearch.umn.edu/bitstream/170236/2/efficientexitpaperaaeasup.pdf>. Acesso em: 25 September 2014. 
PIERANI, P.; RIZZI, P. L. Technology and efficiency in a panel of Italian dairy farms: an SGM restricted cost function approach. Agricultural Economics, 29, 2003. 195-209.

PIESSE, J.; THIRTLE, C.; TURK, J. Efficiency and ownership in Slovene dairying: a comparison of econometric and programming techniques. Journal of Comparative Economics, 22, 1996. 1-22.

REINHARD, S.; LOVELL, C.A.K.; THIJSSEN, G. Econometric estimation of technical and environmental efficiency: an application to Dutch dairy farms. American Journal of Agricultural Economics, 81, 1999. 44-60.

REINHARD, S.; LOVELL, C.A.K.; THIJSSEN, G. Environmental efficiency with multiple environmentally detrimental variables; estimated with SFA and DEA. European Journal of Operational Research, 121, 2000. 287-303.

RESTI, A. Efficiency measurement for multi-product industries: a comparison of recent techniques based on simulated data. European Journal Operational Research, 121, 2000. 559-578.

RIVAS, T.E. Dairy Farm Efficiency and the Analysis o f Milk Production Growth: evidence from Vermont. Connecticut: Dissertation, University of Connecticut, 2003. 167 p.

ROUSE, P.; HARRISON, J.; CHEN, L. Data envelopment analysis: a practical tool to measure performance. Australian Accounting Review, 20, 2010. 165177.

ROWLEY, J.; SLACK, F. Conducting a literature review. Management Research News, 27, n. 6, 2004. 31-39.

SANTOS, J.A.D.; VIEIRA, W.D.C.; BAPTISTA, A.J.M.D.S. Eficiência técnica na produção de leite em pequenas propriedades da microrregião de Viçosa-MG. Revista de Economia e Agronegócio, 2, n. 2, 2004. 261-290.

SANTOS, J.A.; CRUZ VIEIRA, W.; SANTOS BAPTISTA, A.J.M. Eficiência Técnica em Propriedades Leiteiras da Microrregião de Viçosa-MG: uma análise não-paramétrica. Organizações Rurais \& Agroindustriais, 7, n. 2, 2005. 162172.

SAUER, J.; LATACZ-LOHMANN, U. Efficient Innovation in Dairy Production Empirical Findings for Germany. In: ACAES Anais. United Kingdom: Annual Conference of the Agricultural Economics Society, 2013. Disponivel em: $<$ http://ageconsearch.umn.edu/bitstream/137386/2/Sauer_LataczLohmann_GEWISOLA_2012.pdf>. Acesso em: 13 May 2014.

SCHMIDT, P.; SICKLES, R.C. Production Frontiers and Panel Data. Journal of Business \& Economics Statistics, 2, 1984. 367-374.

SEPLAN-RS. Atlas Socioeconômico Rio Grande do Sul, Secretaria do Planejamento e Desenvolvimento Regional, Porto Alegre - Rio Grande do Sul, 2015. 
$<$ http://www1.seplag.rs.gov.br/atlas/conteudo.asp?cod_menu_filho=819\&cod_me nu=817\&tipo_menu=ECONOMIA\&cod_conteudo=1584>. Acesso em: 2 Junho 2015.

SHARMA, K.R.; LEUNG, P.S.; ZALESKI, H.M. Technical, allocative and economic efficiencies in swine production in Hawaii: a comparison of parametric and nonparametric approach. Agricultural Economics, 20, 1999. 23-35.

SHORTALL, O.K.; BARNES, A.P. Greenhouse gas emissions and the technical efficiency of dairy farmers. Ecological Indicators, 29, 2013. 478-488.

SIMAR, L.; WILSON, P.W. Estimation and inference in two-stage, semiparametric models of production processes. Journal of Econometrics, 136, n. 1, 2007. 31-64.

SINGBO, A.G.; LARUE, B. Scale Economies and Technical Efficiency of Quebec Dairy Farms. In: CREATE Anais. Quebéc: Center for Research on the Economics of the Environment, Agri-Food, Transports and Energy, 2014. Disponivel em: <http://ageconsearch.umn.edu/bitstream/182482/2/CREATE20147.pdf. $>$. Acesso em: 25 set. 2014.

SKEVAS, I.; ZHU, X.; SHESTALOVA, V.; EMVALOMATIS, G. An examination of the impact of agri-environmental policies and intensification on the hyperbolic efficiency of Dutch dairy farms. In: EAAE Anais. Ljubljana: Congress Agri-Food and Rural innovations for Healthier Societies, 2014. Disponivel em: <http://ageconsearch.umn.edu/bitstream/182482/2/CREATE20147.pdf. >. Acesso em: 25 set. 2014.

SOLÍS, D. Household productivity and investment in soil conservation: evidence from small-scale hillside farmers in Central America. Connecticut: Dissertation, University of Connecticut, 2005. 176 p.

SOLÍS, D.; BRAVO-URETA, B.E.; QUIROGA, R. Technical efficiency among peasant farmers participating in natural resource management programs in Central America. Journal of Agricultural Economics, 60, 2009. 202-219.

SOUSA, L.O.; CAMPOS, S.A.C.; GOMES, M.F.M. Technical performance of milk producers in the state of Goiás, Brazil in the short and long terms. Revista Brasileira de Zootecnia, 41, n. 8, 2012. 1944-1950.

STANLEY, T.D.; JARRELL, S.B. Meta-Regression Analysis: A Quantitative Method of Literature Surveys. Journal Economics Surveys, 3, 1989. 161-170.

STEENEVELD, W.; TAUER, L.W.; HOGEVEEN, H.; OUDE LANSINK, A.G.J.M. Comparing technical efficiency of farms with an automatic milking system and a conventional milking system. Journal of Dairy Science, 95, 2012. 7391-7398.

TAUER, L. Short-run and long-run efficiencies of New York dairy farms. Agricultural and Resource Economics Review, 22, 1993. 1-9. 
TAUER, L.W. Productivity of New York dairy farms measured by nonparametric malmquist indices. Journal of Agricultural Economics, 49, 1998. 234-249.

TAUER, L.W.; BELBASE, K.P. Technical efficiency of New York dairy farms. Northeastern Journal of Agricultural and Resource Economics, 16, 1987. 1016.

THIAM, A. Primal versus dual farm efficiency: econometric evidence from Senegal. Connecticut: Dissertation, University of Connecticut, 2003.

THIAM, A.; BRAVO-URETA, B.E.; RIVAS, T. Technical efficiency in developing country agriculture: a meta-analysis. Agricultural Economics, 25, 2001. 235-243.

THOMAS, A.C.; TAUER, L.W. Linear input aggregation bias in nonparametric technical efficiency measurement. Canadian Journal of Agricultural Economics, 42, 1994. 77-86.

THOMÉ, A.M.T.; SCAVARDA, L.F.; FERNANDEZ, N.S.; SCAVARDA, A.J. Sales and operations planning: A research synthesis. International Journal of Production Economics, 138, n. 1, 2012. 1-13.

THOMÉ, A.M.T.; HOLLMAN, R.; SCAVARDA, L.F. Synthesis in collaborative planning forecast and replenishment. Industrial Management \& Data Systems, 114, n. 6, 2014. 949-965.

TRAN, K.C.; TSIONAS, E.G. GMM estimation of stochastic frontier model with endogenous regressors. Economics Letters, 118, 2013. 233-236.

TSIONAS, E.G. Efficiency Measurement with the Weibull Stochastic Frontier. Oxford Bulletin of Economics and Statistics, 69, 2007. 693-706.

UDDIN, M.M.; BRÜMMER, B.; PETERS, K.J. Technical efficiency and metatechnology ratios under varying resource endowment in different production systems: a stochastic metafrontier model in Bangladesh dairy farms. China Agricultural Economic Review, 3, 2014. 485-505.

VAN DER VOORT, M.; VAN MEENSEL, J.; LAUWERS, L.; VERCRUYSSE, J.; VAN HUYLENBROECK, G.; CHARLIER, J. A stochastic frontier approach to study the relationship between gastrointestinal nematode infections and technical efficiency of dairy farms. Journal of Dairy Science, 97, 6, 2014. 34983508.

WANG, Q. A technical efficiency analysis of Pennsylvania dairy farms. In: AAEA Anais. Chicago: American Agricultural Economics Association, 2001. Disponivel em: <http://ageconsearch.umn.edu/bitstream/20662/1/sp01wa05.pdf.>. Acesso em: 13 maio 2014.

WORLD BANK. World Development Indicator. Washington, DC: [s.n.], 2005.

XIAOHUA, Y. Productivity, efficiency and structural problems in Chinese dairy farms. China Agricultural Economic Review, 4, 2012. 168-175. 
YÉLOU, C.; LARUE, B.; TRAN, K.C. Threshold effects in panel data stochastic frontier models of dairy production in Canada. Economic Modelling, 27, 2010. 641-647. 


\section{Annex 1 - COREDE Alto Jacuí and Municipalities}

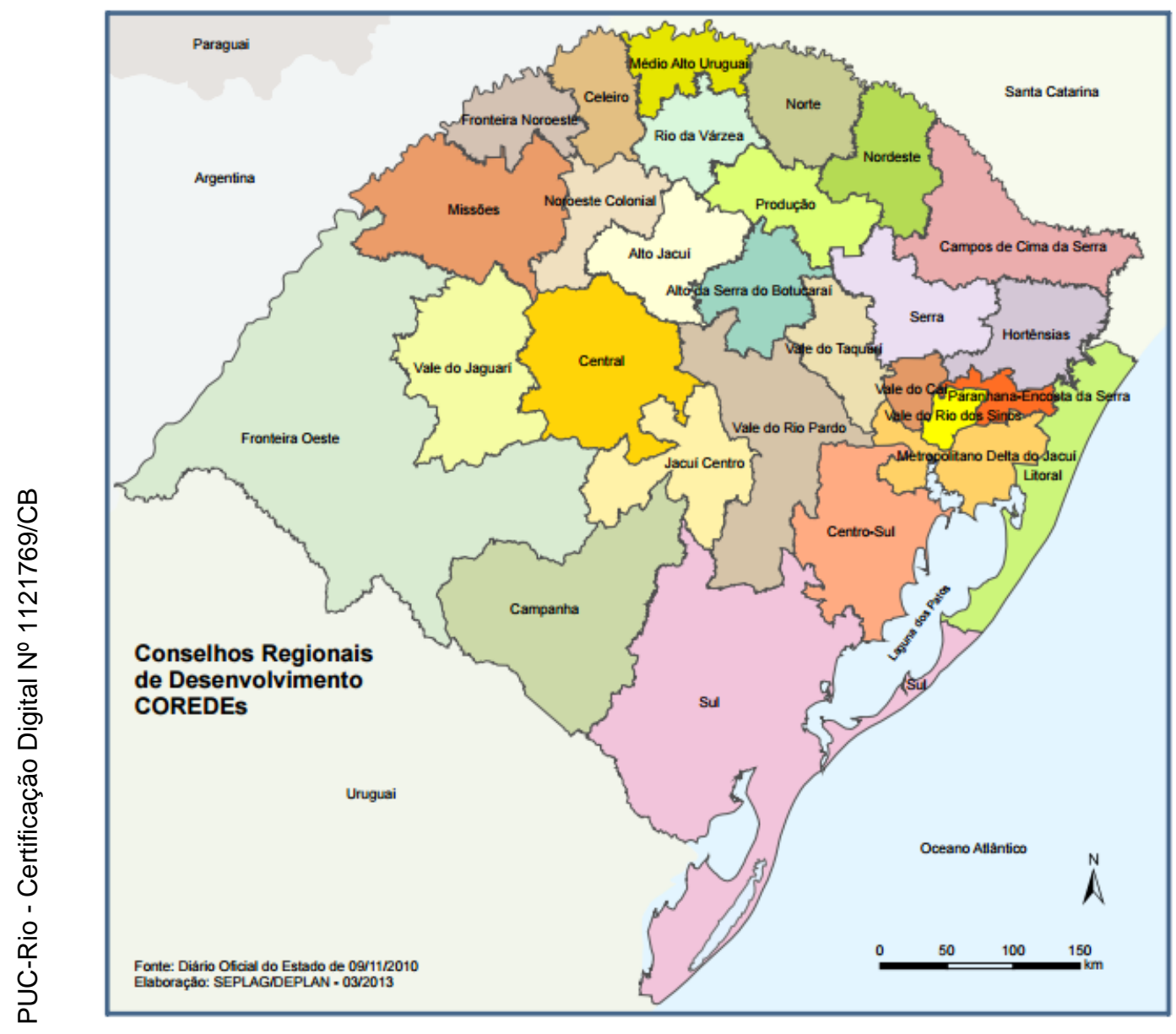

Figure 12: Regions of the COREDE

Source: http://www1.seplag.rs.gov.br/upload/COREDEs 2013(2).pdf 


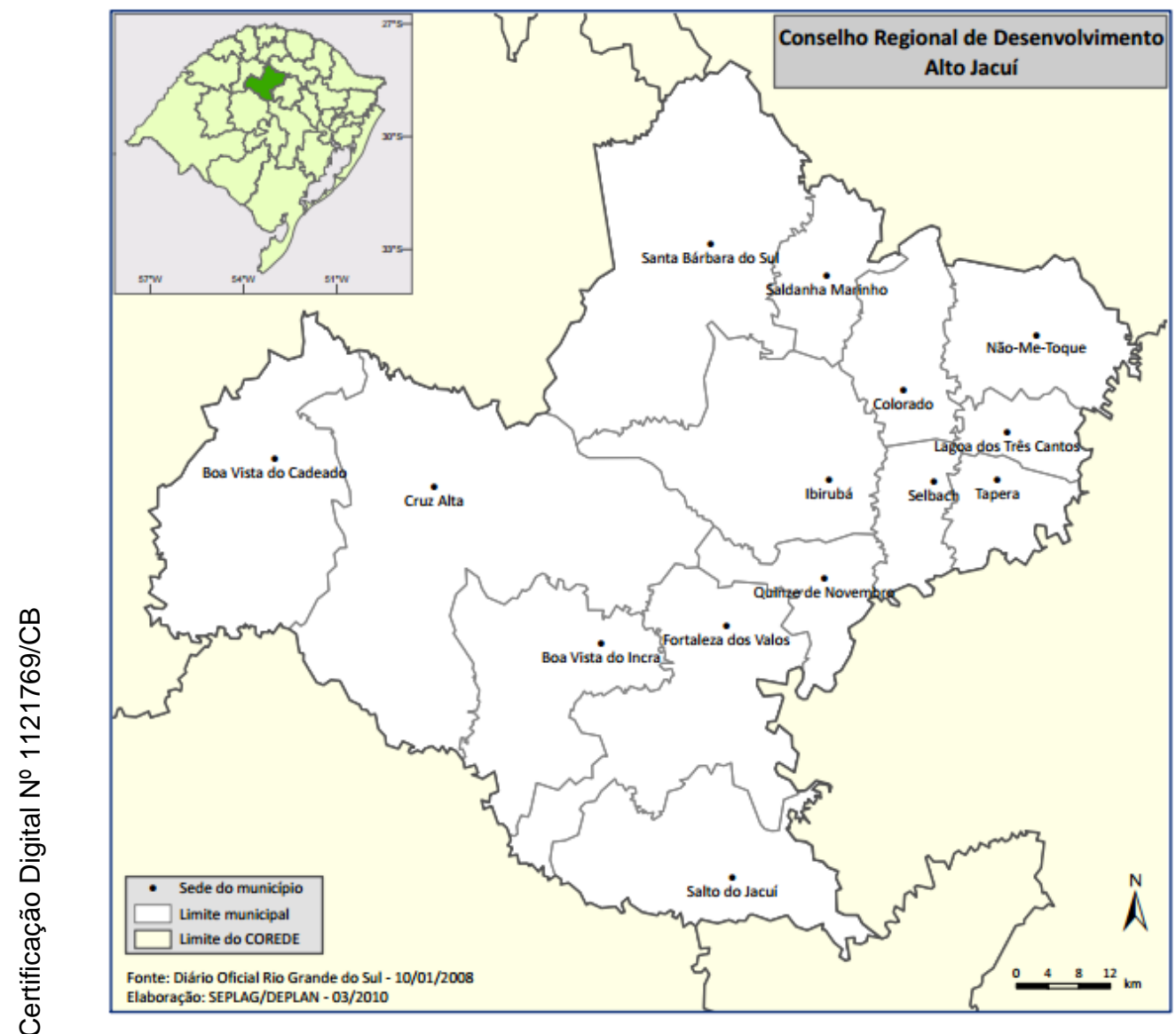

Figure 13: COREDE Alto Jacuí and municipalities

Source: http://www1.seplag.rs.gov.br/upload/MAPAS A4 AltoJacui.pdf 
ANNEX 2 - QUESTIONNAIRE

PESQUISA EM UNIDADES DE PRODUÇÃO LEITEIRA DOS MUNICÍPIOS DO COREDE ALTO JACUÍ

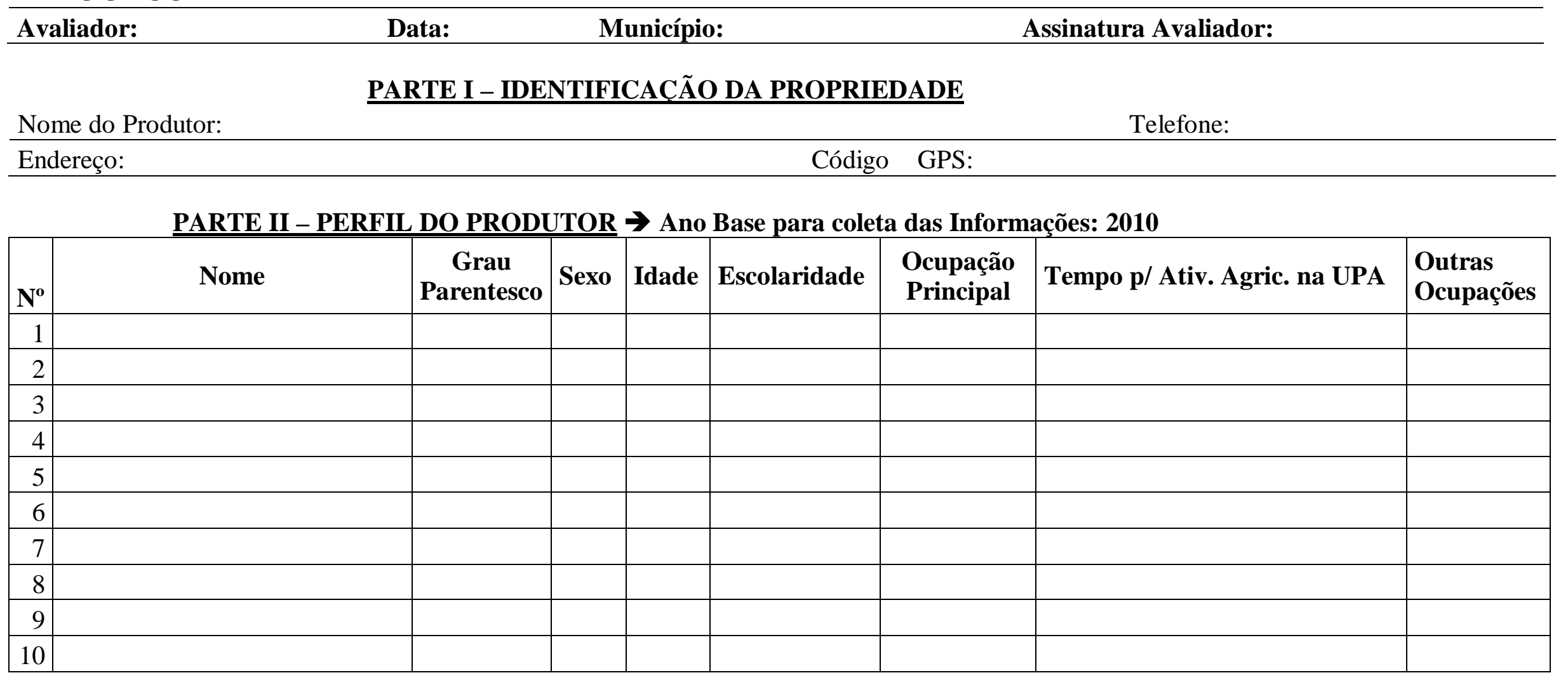

Grau de Parentesco: 1. O responsável; 2. Cônjuge; 3. Filhos; 4. Netos; 5. Pais; 6. Avó; 7. Sobrinho; 8. Enteado; 9. Dependentes.

Escolaridade: 1. Analfabeto; 2. $1^{\circ}$ Grau Incompleto; 3. $1^{\circ}$ Grau Completo; 4. Seg. Grau Incompleto; 5. Seg. Grau Completo; 6. Superior; 7. Não Alfabetizado.

Ocupação Principal: 1. Agricultor; 2. Assalariado Agrícola Permanente; 3. Assalariado Agrícola Temporário; 4. Do Lar; 5. Estudante; 6. Aposentado; 7. Emprego Doméstico; 8. Construção Civil; 9. Professor; 10. Funcionário Público; 11. Comerciário; 12. Comerciante; 13. Feirante; 14. Motorista; 15. Artesanato; 16. Turismo; 17. Terceirização de serviços, 18. Outros............

Tempo dedicado para atividades agrícolas: 1 . Tempo Integral; 2. Metade do tempo; 3. Eventual; 4. Nenhum.

Outras ocupações: 1. Agricultor; 2. Assalariado Agrícola Permanente; 3. Assalariado Agrícola Temporário; 4. Do Lar; 5. Estudante; 6. Aposentado; 7. Emprego Doméstico; 8. Construção Civil; 9. Professor; 10. Funcionário Público; 11. Comerciário; 12. Comerciante; 13. Feirante;

14. Motorista; 15. Artesanato; 16. Turismo; 17. Terceirização de serviços; 18. Outro 
2.3 Algum membro da familia participa de atividades comunitárias?

( ) Não ( ) Sim

( ) Associação de moradores/comunidade

( ) Clube de Mães （ ） Grupo de Terceira Idade

( ) Grupo Reliogioso/Igreja

( ) Grupo Artístico/Cultural ( ) Atividade Esportiva

( ) Outro. Qual:

2.4 Algum membro da família desenvolve atividade alternativa para gerar renda?

( ) Não （） Sim. Qual:

2.5 Quantos membros da família tem problemas de saúde que necessitam de acompanhamento médico? Quais os problemas?

Onde são atendidos?

\section{RESPONSÁVEIS PELA ATIVIDADE LEITEIRA}

Quem?

3.1 Há quanto tempo estão na atividade leiteira:

3.2 Número de familiares envolvidos na atividade leiteira:

3.2.1 Quantos recebem remuneração:

3.2.2 Remuneração média mensal coletiva (em R\$):

3.3 Trabalhadores

\begin{tabular}{l|l}
\hline 3.3 .1 Empregados Efetivos & 3.3 .2 Diaristas (Temporários) \\
\hline $\mathrm{N}^{\circ}:$ & $\mathrm{N}^{\circ}:$ \\
\hline Remuneração Média (R\$): & Remuneração Média (R\$): \\
\hline Paga Encargos: & Época que contrata: \\
\hline
\end{tabular}

3.4 Quantidade de filhos que não continuam residindo na propriedade:

3.4.1 Por quê?

3.4.2 Com que frequência esses filhos vão a propriedade:

3.4.3 Os filhos, mesmo residindo na cidade, recebem remuneração referente a atividade leiteira? ( ) Não ( ) Sim. Quanto (média por filho)?

3.5 Haverá sucessão (continuidade) na atividade leiteira de sua propriedade?

( ) Não ( ) Sim

( ) Filhos ( ) Outros: 
3.6 Você gostaria que algum filho (filha) continuasse a trabalhar com a produção leiteira?

( ) Não ( ) Sim

3.7 Você já é aposentado?

( ) Não. Quando ocorrer, vai continuar na propriedade? Porque?

( ) Sim. Há quanto tempo?

Pretende continuar na atividade leiteira? Porque?

\section{PARTE III - IDENTIFICACÃO DOS FATORES DE PRODUCÃO}

\section{TERRA}

\begin{tabular}{lll}
\hline 4.1 Origem & ( ) Comprada ( ) Herança & ( ) Herança e Compra \\
& ( ) Assentamento Agrário & ( ) Usocapião
\end{tabular}

4.2 Uso da terra
( ) Toda arrendada
( ) Parte arrendada e parte própria
( ) Toda própria

4.3 Área total da propriedade (ha):

4.3.1 Dividida em mais do que uma área:

( ) Não ( ) Sim, quantas:

Área 1_ hectares ___ cultura

Inverno Área 2_ hectares___ cultura

Área 3_ hectares __ cultura

Área 4_ hectares __ cultura

Área 5_ hectares __ cultura

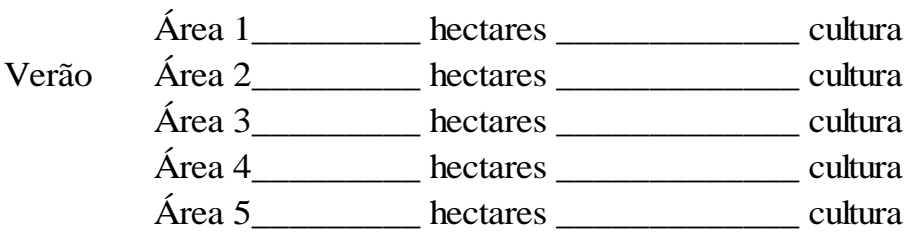

4.3.2 Área arrendada para terceiros (ha):

( ) Não ( ) Sim, quantas:

4.3.3 Área arrendada de terceiros (ha):

( ) Não ( ) Sim, quantas:

( ) Atividade Leiteira

( ) Outras

4.3.4 Tem área destinada a preservação permanente?

( ) Não ( ) Sim. Quantos hectares? 
4.3.5 Tem área destinada ao reflorestamento?

\begin{tabular}{ll}
$($ ) Não & $($ ) Sim. Quantos hectares? \\
\hline 4.3.6 Área destinada a atividade leiteira \\
No inverno __ hectares \\
No verão $\quad$ hectares \\
Área plantada para silagem__ herctares
\end{tabular}

\section{REBANHO}

5.1 Bovinos de leite (em unidades)

5.1.1 Vacas em lactação:

5.1.2 Vacas secas:

5.1.3 Outras fêmeas

Novilhas:

Terneiras (até 10 meses):

\subsubsection{Reprodutores:}

5.2 Rebanhos de outras espécies (em unidades)

5.2.1 Equinos:

5.2.2. Súnos:

5.2.3 Aves:

5.2.4 Ovinos:

5.2.5 Caprinos:

5.3 Raça do rebanho leiteiro (em unidades)

5.3.1 Holandesa

Vacas:

Novilhas:

Terneiras:

5.3.2 Jersey

Vacas: Novilhas: Terneiras:

\subsubsection{Zebuínos}

Vacas: Novilhas: Terneiras:

\subsubsection{Outras. Quais?}

Vacas: Novilhas: Terneiras:

Observações:

5.4 Tem cães na propriedade?

( ) Não

( ) Sim

Ajuda no trabalho com animais em geral? ( ) Sim ( ) Não

Vacina os cães? ( ) Sim ( ) Não 


\section{ALIMENTAÇÃO}

\subsection{Pastagens}

6.1.1 Inverno

Aveia Preta (ha):

Custo Total Período (R\$):

Aveia Branca (ha):

Custo Total Período (R\$):

Alfafa (ha):

Custo Total Período (R\$):

Azevém (ha):

Custo Total Período (R\$):

Leguminosas (ha):

Custo Total Período (R\$):

Outras (ha): Quais?

Custo Total Período (R\$):
6.1.2 Verão
Tifton (ha):
Custo Total Período (R\$):
Milheto (ha):
Custo Total Período (R\$):
Sorgo (ha):
Custo Total Período (R\$):
Sudão (ha):
Outras (ha):
Quais?
Custo Total Período (R\$):
Custo Total Período (R\$):

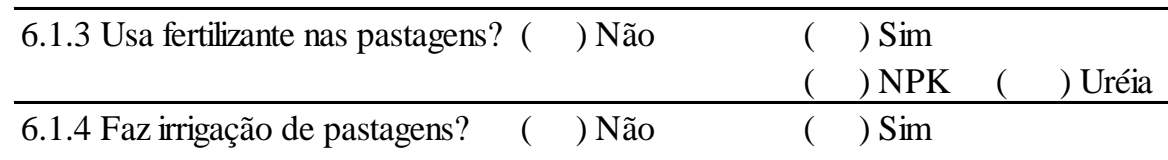

6.2 Usa Silagem: $\quad($ ) Não $\quad(\quad) \operatorname{Sim}$

Qual: ( ) Milho

( ) Sorgo

Qtidade ensilada: toneladas

( ) Outras gramíneas

Compra silagem conservada? ( ) Não área plantada (ha)

Custo Total Silagem - Anual (R\$):

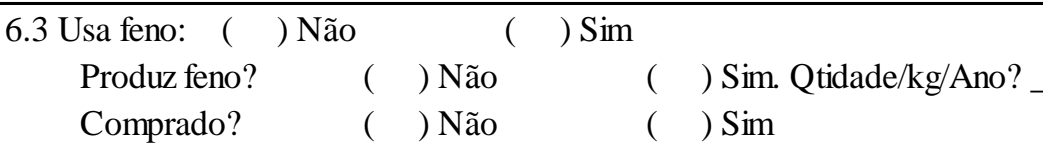

Qual: ( ) Alfafa

( ) Tifton

( ) Outras gramíneas

Qtidade/kg/Fardo?

Custo Total Feno - Anual (R\$):

\begin{tabular}{cll}
\hline 6.4 Usa Concentrado: & ( ) Não & ( ) Sim \\
Comprado? & ( ) Não & ( ） Sim. Onde?
\end{tabular}

Qtidade fornecida por animal/dia:

$\begin{array}{lr}\text { Vacas em lactação: } & \mathrm{Kg} \\ \text { Vacas secas: } & \mathrm{Kg} \\ \text { Terneiras: } & \mathrm{Kg} \\ \text { Novilhas: } & \mathrm{Kg}\end{array}$

Custo Médio Mensal (R\$):

6.5 Mineralização

Usa sal mineralizado? （ ） Não ～～） Sim

Qtidade (g/animal/dia)?

Onde compra (empresa)? 
6.6 Em relação a utilização do leite em pó

Qual o consumo/terneira/período de amamentação?

Custo Período (R\$): Tempo:

6.7 Utiliza assistência técnica no manejo nutricional?

( ) Não ( ) Sim. Quem?

6.8 Gostaria de receber assistência técnica em que área?

( ) Nutricional ( ) Reprodução

( ) Sanidade ( ) Gestão

( ) Outro. Qual?

\section{REPRODUÇÃO}

\begin{tabular}{llll}
\hline 7.1 Faz inseminação artificial? ( ) Não & $(\quad$ ) Sim & $\begin{array}{l}\text { ( ) Parcial } \\
\text { Qual categoria? }\end{array}$ \\
\hline 7.2 Usa touro para repasse? & $($ ) Não & $(\quad$ ) Sim &
\end{tabular}

$7.3 \mathrm{~N}^{\circ}$ de Inseminações/vaca:

7.4 Custo médio de uma inseminação (R\$):

7.5 Peso ao entoure ou Inseminação:

7.6 Idade à parição de novilhas:

7.7 Intervalo entre partos:

7.8 Tempo de período seco:

7.9 Uso de biotecnologias de reprodução além da I.A.?

( ) Não ( ) Sim. Qual?

7.10 Tem assistência técnica veterinária em reprodução?

( ) Não ( ) Sim. Quem?

( ) Veterinário particular ( ) Cooperativa （ ) Outro:

Qual frequencia:

\section{PARTE IV - IDENTIFICAC̄̃̃O DA PRODUCC̃̃}

\section{PRODUÇÃO}

8.1 Produção diária total (litros):

8.1.1 Entrega (litros):

8.1.2 Consumo próprio (litros):

8.1.2.1 In natura (litros):

8.1.2.2 Transformação

( ) Não. Porque:

( ) Sim. Quais produtos: 


\begin{tabular}{|c|c|}
\hline \multirow{3}{*}{ ( ) Queijo } & ( ) Vende \\
\hline & ( ) Consome \\
\hline & ( ) Vende e consome \\
\hline \multirow{3}{*}{ ( ) Iogurte } & ( ) Vende \\
\hline & ( ) Consome \\
\hline & ( ) Vende e consome \\
\hline \multirow{3}{*}{ ( ) Nata/manteiga } & ( ) Vende \\
\hline & ( ) Consome \\
\hline & ( ) Vende e consome \\
\hline \multirow{3}{*}{ ( ) Sorvete } & ( ) Vende \\
\hline & ( ) Consome \\
\hline & ( ) Vende e consome \\
\hline \multirow{3}{*}{ ( ) Doce de leite } & ( ) Vende \\
\hline & ( ) Consome \\
\hline & ( ) Vende e consome \\
\hline \multirow[t]{3}{*}{ ( ) Outros: } & ( ) Vende \\
\hline & ( ) Consome \\
\hline & ( ) Vende e consome \\
\hline
\end{tabular}

8.1.2.3 Receita dos produtos em transformação (média mensal-R\$):

8.2 Qual o período de maior produção e sua quantidade

\begin{tabular}{|l|l|l|}
\hline Estações & Quantidade (média litro/estação) & Preço médio por litro \\
\hline Verão & & \\
\hline Inverno & & \\
\hline Primavera & & \\
\hline Outono & & \\
\hline
\end{tabular}

8.3 Investe no aumento de produção? ( ) Não

( ) Sim. Quanto?

Qual a fonte?

Em quais itens?

8.4 Qualidade do Leite

\begin{tabular}{|l|l|}
\hline Qualidade Média Leite & Quantidade/dia \\
\hline ( ) $<200.000$ CCS & \\
\hline ( ) $200.000-500.000$ CCS & \\
\hline ( ) $500.000-1.000 .000$ CCS & \\
\hline ( ) $>1.000 .000$ CCS & \\
\hline
\end{tabular}


8.5 Forma de comercialização do leite produzido

\begin{tabular}{|c|c|c|c|c|c|c|}
\hline & \multirow{2}{*}{ Identificação } & \multirow{2}{*}{ Há quanto tempo? } & \multirow{2}{*}{ Quantidade } & \multirow{2}{*}{$\begin{array}{l}\text { Qual a forma de } \\
\text { pagto? }\end{array}$} & \multicolumn{2}{|c|}{ Valor da bonificação } \\
\hline & & & & & Qlidade & Qtidade \\
\hline \multicolumn{7}{|l|}{ Empresa } \\
\hline \multicolumn{7}{|l|}{ Associação } \\
\hline \multicolumn{7}{|l|}{ Cooperativa } \\
\hline Outros & & & & & & \\
\hline
\end{tabular}

8.6 Tem obstáculos na comercialização da produção?

( ) Não ( ) Sim. Quais:

8.7 Frequencia da coleta do leiteiro

( ) Diária ( ) 48 horas （ ) 72 horas

PARTE V - IDENTIFICACÃO DO CAPITAL E DOS CUSTOS DE

PRODUCÃ̃

9 CAPITAL E CUSTOS

9.1 Ordenhadeira

9.1.1 Qual tipo de ordenha utiliza?

( Manual （ ） Mecânica/Balde ao Pé （ ） Mecânica Canalizada

9.1.2 Utiliza água na higiene da ordenha?

( ) Não ( ) Sim

9.1.3 Local de ordenha:

( ) Sala de ordenha

( ) Estábulo

( ) Alvenaria

( ) Madeira

( ) Mista

9.1.4 Uso de sanitizantes pré e pós ordenha
Pré-dipping:
( ) Não ( ) Sim
Pós-dipping:
( ) Não ( ) Sim

9.2 Resfriamentos

( ) Tanque de expansão

( ) Resfriador

9.3 Eletrificação Rural
( ) Rede Pública;
( ) Gerador;
( ) Monofásica;
( ) Sem eletrificação;
( ) Trifásica;
( ) Outros:

Custo Médio Mensal de Energia Elétrica (R\$): 


\subsection{Telefonia Rural}
( ) Linha;
( ) Comunitária/ramal;
( ) Internet;
( ) Celular;
( ) Rádio;
( ) Outro:

Custo Médio Mensal de Telefone (R\$):

9.5 Meios de Comunicação
( ) Rádio amador;
( ) Celular;
( ) Telefonia rural;
( ) Internet;
( ) Outro:

9.6 Prestação de serviços fora da propriedade (Colheita, Secagem, Transporte, e serviços como alambrador, roçadas, construção, etc)

( ) Contrata. Quais?

( ) Realiza. Quais?

9.7 Custo com Funrural (R\$): e ITR (R\$):

9.8 Custo mensal com manejo sanitário (vacinas, vermífugos, medicamentos):

9.9 Quanto às benfeitorias e instalações disponíveis no estabelecimento

\begin{tabular}{|l|l|l|l|l|}
\hline \multicolumn{1}{|c|}{ Especificação } & Quantidade & Área & Padrão* & Ano de construção \\
\hline Casa do proprietário & & & & \\
\hline Casa empregado & & & & \\
\hline Cercas (metros) & & & & \\
\hline Galpão & & & & \\
\hline Galinheiros & & & & \\
\hline Pocilgas & & & & \\
\hline Silos & & & & \\
\hline Outros & & & & \\
\hline
\end{tabular}

*Padrão: 1 - Madeira; 2 - Alvenaria; 3 - Metálico; 4 - Misto.

Custo Médio Mensal de Manutenção de Benf/Instal. (R\$):

9.10 Quais as máquinas e equipamentos são utilizadas na atividade leiteira?

\begin{tabular}{|c|c|c|}
\hline Especificação & Quantidade & Ano \\
\hline \multicolumn{3}{|l|}{ Cerca elétrica (metros) } \\
\hline \multicolumn{3}{|l|}{ Resfriador } \\
\hline \multicolumn{3}{|l|}{ Ordenhadeira } \\
\hline \multicolumn{3}{|l|}{ Tarros } \\
\hline \multicolumn{3}{|c|}{ Outros } \\
\hline & & \\
\hline & & \\
\hline & & \\
\hline & & \\
\hline & & \\
\hline & & \\
\hline & & \\
\hline & & \\
\hline
\end{tabular}

Custo Médio Mensal de Manutenção de Máq/Equip (R\$):

Custo Médio Mensal de Combustível de Máq/Equip (R\$): 
10 GESTÃO AMBIENTAL

10.1 Mata

10.1.1 Na propriedade ainda há alguma área de mata nativa?

( ) Não ( ) Sim. Qtos ha?

10.2 Relevo

10.2.1 O relevo da sua propriedade é predominantemente:

( ) Plano ( ) Acidentado

10.3 Solo

10.3.1 Você considera como importante o uso de práticas de conservação do solo?

( ) Não. Porque?

( ) Sim. Quais são as práticas utilizadas na sua propriedade para a conservação do solo?

( ) Terraceamento ( ) Rotação de culturas

( ) Plantio direto ( ) Outras. Quais?

10.3.2 Na sua propriedade há problemas relacionados a erosão do solo?

( ) Não ( ) Sim ( ) Parcialmente

10.4 Água

10.4.1 Algum arroio, sanga ou rio corta sua propriedade?

( ) Não ( ) Sim. Há mata ciliar ao longo deste?

( ) Não ( ) Sim. Qtos metros em média a cada margem?

10.4.2 Qual é a origem da água que você utiliza em sua propriedade?

$\begin{array}{lll}\text { ( ) Rede pública } & \text { ( ) Vertente } & \text { ( ) Poço artesiano } \\ \text { ( ) Rede comunitária } & \text { ( ) Poço comum } & \text { ( ) Arroio } \\ \text { ( ) Açude } & \text { ( ) Outro. Qual? } & \end{array}$

10.4.3 Faz tratamento da água?

( ) Sim ( ) Não. Porque?

10.4.4 Onde a água é descartada depois da utilização na atividade leiteira?

Custo Médio Mensal da Água (R\$):

10.5 Saneamento

10.5.1 Tem saneamento básico?

( ) Não. Porque?

( ) Sim. Qual? ( ) Patente - latrina ( ) Fossa séptica ( ) Outro:

10.6 Resíduos

10.6.1 Realizam a tríplice lavagem das embalagens de produtos químicos?

( ) Sim ( ) Não ( ) Parcialmente

10.6.2 Em que local descartam as embalagens de produtos químicos?

10.6.3 O que é feito com o resíduo orgânico proveniente da produção leiteira?

10.6.4 O que é feito com o resíduo orgânico proveniente do uso doméstico da propriedade?

10.6.5 O que é feito com o resíduo seco?

10.6.6 Tem algum custo com esses resíduos (média mensal-R\$)? 


\section{GESTÃO DA PROPRIEDADE}

11.1 Produtor, quanto custa produzir um litro de leite?

Quais os valores e Sr leva em consideração?

Como realiza o cálculo?

11.2 Realiza algum tipo de planejamento?

( ) Não ( ) Sim. Quais:

Há quanto tempo?

11.3 Utiliza financiamento?

( ) Não ( ) Sim

Para qual atividade? ( ) Leiteira （ ) Outras. Quais?

11.4 A contabilidade é realizada na propriedade?

( ) Não ( ) Sim. Qtos funcionários trabalham na contabilidade?

11.5 A contabilidade normalmente está atualizada?

( ) Sim. ( ) Não. Porque?

11.6 O gestor da propriedade recebe do setor contábil (interno ou externo):

Relatório de receitas, custos e despesas (em que é apurado o lucro ou prejuízo)?

( ) Sim. ( ) Não. Porque?

Relatório contendo uma análise econômica e financeira da empresa?

( ) Sim. ( ) Não. Porque?

Relatório de custos?

( ) Sim. ( ) Não. Porque?

11.7 Em relação aos relatórios citados, realiza algum tipo de análise?

( ) Sim. Quais?

( ) Não. Porque?

11.8 A propriedade tem:

Controle de estoques?

( ) Sim. ( ) Não. Porque?

Controle de custos? Caso tenha, como é calculado o custo de produção?

( ) Sim. ( ) Não. Porque?

Informações de natureza física - horas-homens, insumos e horas-máquinas?

( ) Sim. ( ) Não. Porque? 
IMPRESSÕES DO OBSERVADOR (para preenchimento dos bolsistas)

1. Como você classificaria o sistema de produção dessa propriedade?

2. O produtor teve boa vontade em responder o questionário?

3. Observações

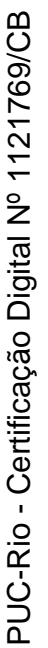

